\title{
الادارة الاستراتيجية بين الفلسفة والتنفيذ
}

\section{الركور / محمد مخمد السيد الطوخى}

\section{الأستاذ الشارك بأكاد يمية العلوم الشرطية بالشارقة}

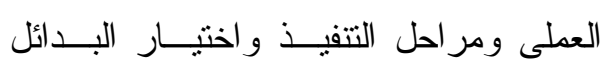
بمعرفة الادارة الاستر اتيجية الرشيدة والاخذ

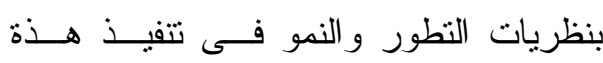
الاستر اتيجيات برشد وقناعة كافـــة المـــوارد البشرية العاملة فى المنظمة بعد التفاعل فـى بـى

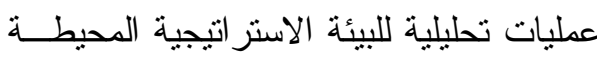
بالمنظمة و المؤثرة فيها.

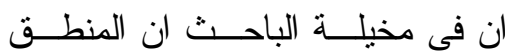
و الفكر الاستر اتيجى لكافة الموارد البـشرية

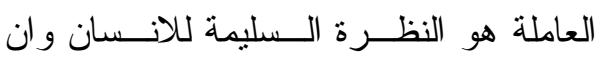

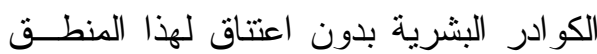

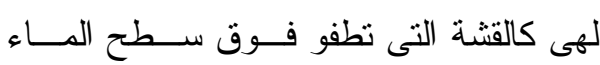
تذهب بها الرياح اينما تذهب. لذا فقد حاولنا جاهدين فى هذا البحث

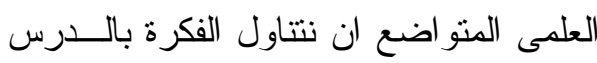

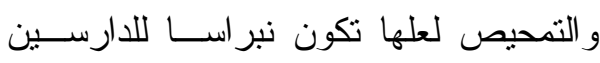

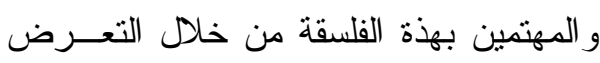
للمبادئ الاساسية للادارة الاستر اتيجية وتنيان اهمية تفعيل الكوادر البشرية للمنطق والفكر الفئه الاستر اتيجى فى اختيار البديل الاســتر اتيجى

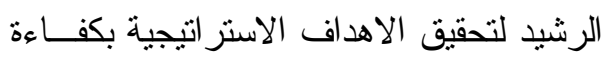

عندما شر ع الباحث فى تـاليف هــــا

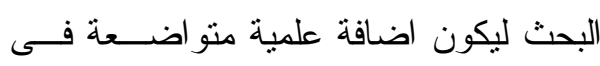

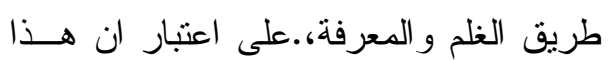

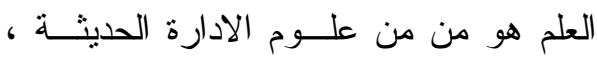

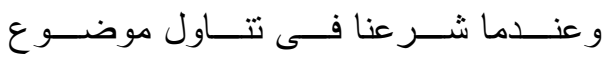
الاستر اتيجية بالثرح و التحليل راى الباحث

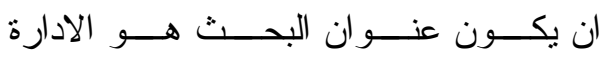
الاستر اتيجية بين الفلسفة و التتفيذ.

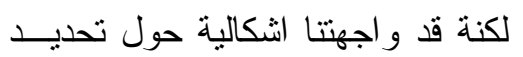
الشئ الاساسى و الحاكم فى هذا العلم المتطور

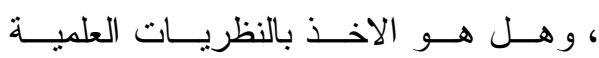

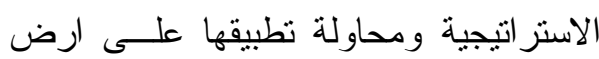

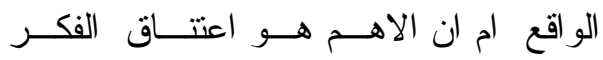

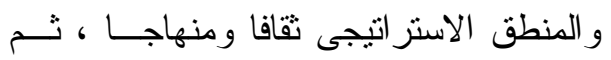
ياتى بعد ذلك الدور المهم لعلم الاســتر اتيجية

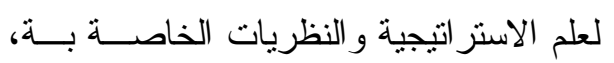

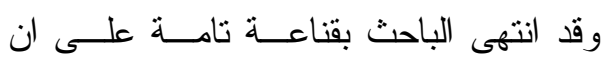

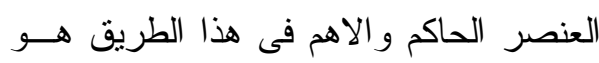

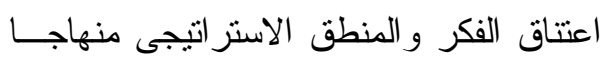

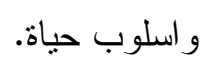

ثم ياتى بعد ذلك مو ائمة هذا المنطــق و هذة النقافة وهذا الاعتتاق من خلال النطبيق 


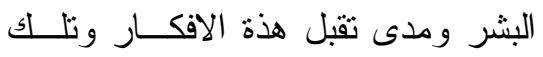
الثقافة فى فاعلية الادارة الاســنز اتيجية وبذللك تسعى الدراسة الحاليــة إلــى

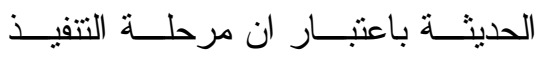

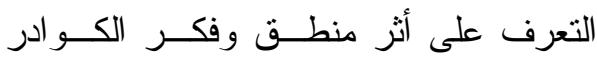
الاستر اتيجى لاتتفك عر اها مع مر احسل مرحل البشرية في تحقيق التوافق والاتــساق فـى لـى

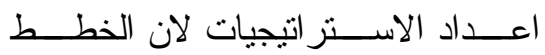
فلسفة ادارتها العـصرية لاســيما إذا كــان

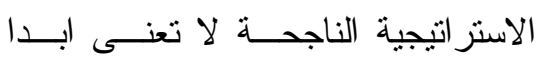

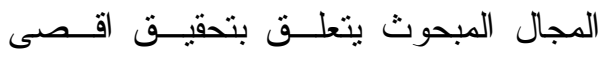

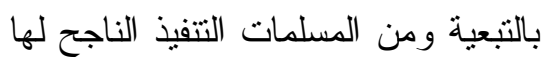
معدلات التميز و الكفاءة فى مجال علوم الفكر الاستز اتيجى الرشــبد وعلاقتـــة بالمبــادئ الاساسية للادارة الاستر اتيجية.

مبدع ومــرن للتعامـل مـــع البــدائل

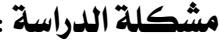

الاستراتيجية المتعددة فى ظل المؤثزات البشرية وو البيئية المتعددة.

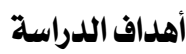

يتمنل الهذف الأساسي لهذه الدراسة في

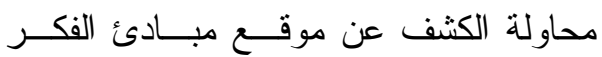
و المنطق الاستر اتيجي فــى حلقـات الادارة الاستر اتيجية المتعددة، وذلـــك مسـن خــلال الأهداف الثالية: - الية

ا ـ التعرف على المبادئ الاساسية للادارة

$$
\text { الاستر اتيجية. }
$$

r. التعرف على مفهوم الدارة الاستر اتيجية ومدى تاثر ها بالسياسة و المنطق و الفكر

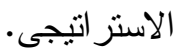

r. التعرف علــى اســتر اتيجية المـــوارد

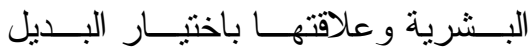

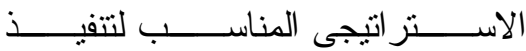

$$
\begin{aligned}
& \text { الاستر اتيجية. } \\
& \text { تاتى أهمية الموضـــوع المبحــوث } \\
& \text { و المتمثل في الغوص في افكار وثقافــة }
\end{aligned}
$$


المبحـــــث الاول : المبــــادئ الأساســـية لـــلإدارة

الاستراتيجية

ان المبـــادئ الاساســـية لـــلادارة

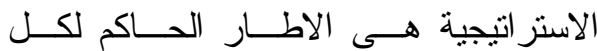

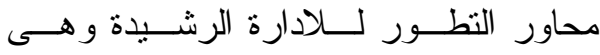
فـــ نفـس الوقــت تمثتـل منظومـــة مــن

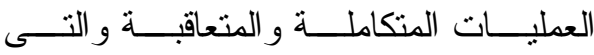

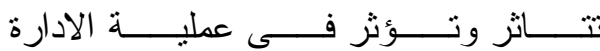

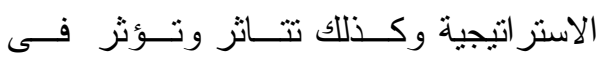

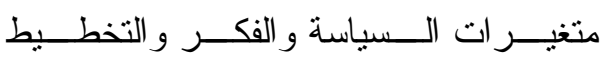
الاستر اتيجى.

وذلك بما يتضمن تحقيق ميزة تتافسية

للمنظمة وتعظيم انجاز اتها فى مجال انـشطة

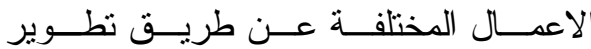
استر اتيجيات فعالة لتحقيق اهداف المنظمـــة باعتبار ان الادارة الاستر اتيجية تعنسى ادارة

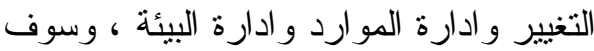
نتتاول در اسة هذا المبحث من خلال المطالب

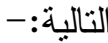

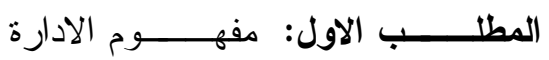
الاستر اتيجية.

المطلـــب الثـــانى:مـــــتويات الادارة الاستر اتيجية.

المطلب الثالث :السياسة و التخطيط و الفكر

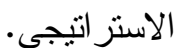

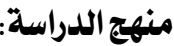

يستخدم الباحــث المـنـهج الوصــفي

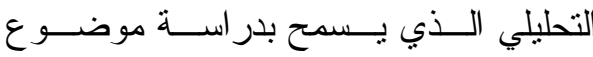

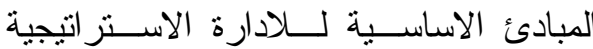
موضحا مفهومهــا ومسـستوياتها وموضــــا العلاقة بين المنطق و الفكر الاستر اتيجى فـى تفعيل هذه المبادئ ووضعها موضع التتفيــذ الرشيد.

هيكل الدراسة:

المبحث الاول: المبادئ الاساسـية لــلادارة الاستر اتيجية.

الاول : مفهـــــــوم الادارة المطا الاستر اتيجية.

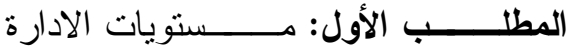

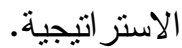

المطلب الثالث: السياسة و التخطيط و الفكر الاستر اتيجى.

المبحث الثانى: استر اتيجية الموارد البشرية و المنطق و البيئة الاستر اتيجية. المطلب الاول: المنطق الاستر اتيجى. المطلب الثـــى: البـــائل الاســتر اتيجية و البيئة.

المطلــب الثالـــثـاســـنز اتيجية المـــوارد

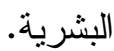

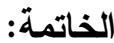

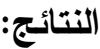

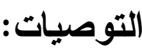


استر اتيجيات فعَّالة لتحقيق أهداف المنظمــة،

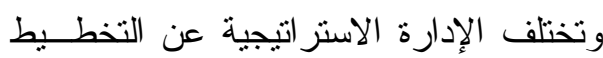
الاستر اتيجى و التخطيط التشغيلى، فــالإدارة الاستر اتيجية هـــ ثـــرة لتطـــور مفهــوم التخطبط الاستز اتيجى، وتوسيع لنطاقه. إن مــن المهــام الرئيسـية لــالإدارة

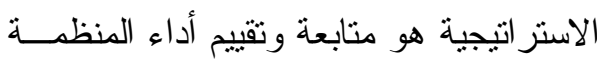
كنظام منكامل، ويتكون من بنية متفاعلة من الأنظمة الوظيفية الفرعية، فإلى جانب تحليل

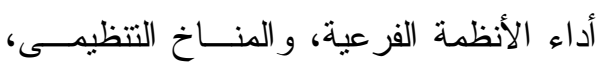
و الثقافة التنظيمية، وما تتضمنه هذه المجالات و الأنظمة من عناصر قوة وضعف. وحيث ان للمنظمة طموحات مستقبلية اى ان ثريد اكثر مما يتجة الية الواقع فــان

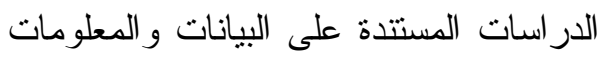
الإحصائية تساعد المنظمـــة علــى موائمـــة

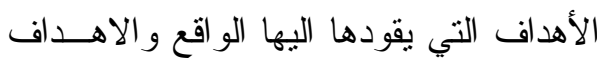
التي تريد ان تصلها لكى تتوصل الى اهداف

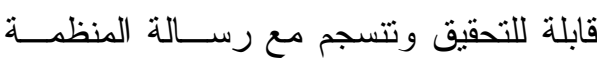
القادمة (ץ). r - أهمية الإدارة الاستر اتيجية: تتضح أهمية الإدارة الاستر اتيجية من الإدنرانه

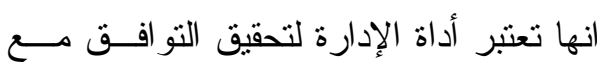

(Y) د.مشيرة السعداوى،استر اتيجية العمل الاحصائى

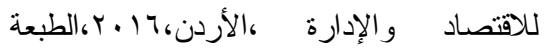

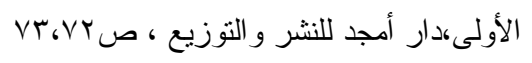

\section{المطلب الاول : مفهوم الإدارة الاستراتيجية}

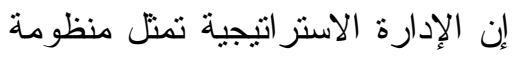

من العمليات المتكاملة ذات العلاقة بتحليـلـل

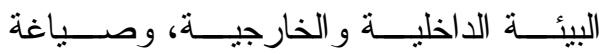

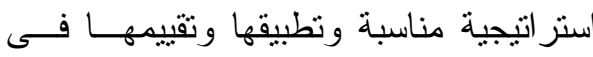

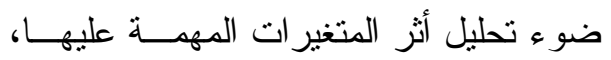
وذلك بما يتضمن تحقيق ميـزة اســتر اتيجية للمنظمة، وتعظيم إنجاز ها فى أنشطة الأعمال المختلفة.

الإدارة الاستر اتيجية هى تلــــ الإدارة

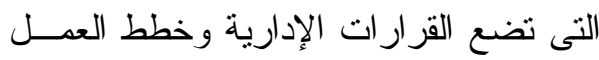

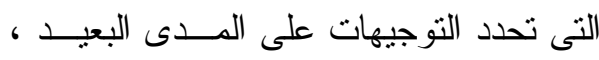

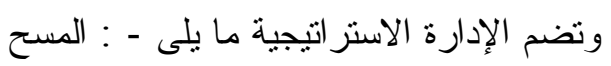

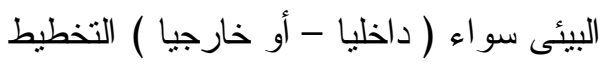

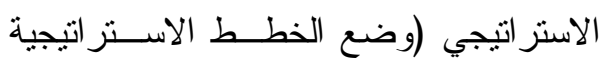
بعيدة المدى) التطبيق الاستر اتيجي - و التحكم و التقييم لذلك فإن در اسة الادارة الاستر اتيجية التئية

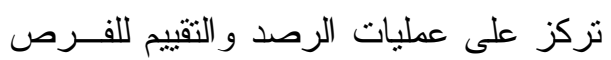

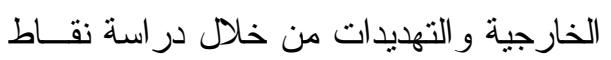
القوة و الضعف (1). وقد عرّف جليك (Glueck): الإدارة

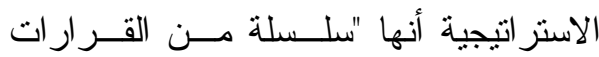
و الأفعال التى نقود إلى نطوير استر اتيجية أو لئي

(1) Casey A and Goldman E F. 2010. Enhancing the Ability to Think Strategically: A Learning Model. Management Learning, 41(2):167185 
من نشاط الأعمال أكثر عالمية، وأقل محلية

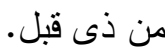
التغير التكنولوجى:

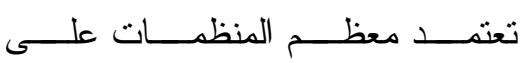

التكنولوجيا؛ لتحقيق ميزة نتافسية ضــرورية

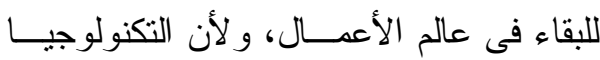
تتغير بصورة مذهلة وسريعة؛ فــإن عـدم مو اكبة هذا التغير يضع المنظمة فى مواجهة تهديد حقيقى.

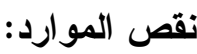
من الواضح أن الموارد الطبيعية فــى تتاقص مستمر ؛ لـــللك يتطلـبـ فــى الإدارة الاستر اتيجية وضع خطط طويلة للــصول علــى المـــو اد الأوليــة بطريقـــــة عقلانيـــة

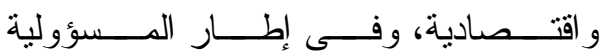

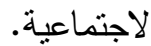

التحول من المجتمعـات الــصناعية إلـى

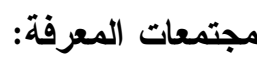
أصبحت المعرفة قــوة اســتراتيجية، ويمكن أن تُشكل ميزة استر اتيجية فى مجــال

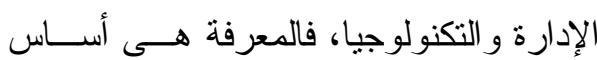

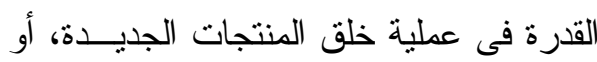
نطوير المنتجات الحالية، وهي أساس القدرة فى الوصول إلى مستويات عالية من النوعية والإبداع الثقنى، إن المعرفة ضرورية لتتفيذ

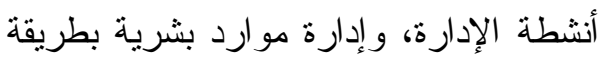
تضمن تحقيق الكفاءة و الفاعلية.
بيئتها (")، وخاصة فيما يتعلق بإدارة الجــودة

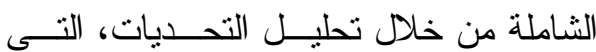
نو اجه الإدارة، وهذه التحديات تتمثل فى: تسارع التغير الكمى والنـــوعى فــــ بيأســة

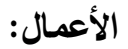

يظهر التغير بجلاء أكثر فــى البنيـــة

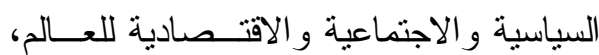
وفى تطور التكنولوجيا و البرمجيات المعقدة، و الثقنيات المتطورة لأجهزة الاتصال؛ لـــللك

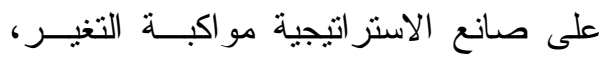
وليس مو اجهته. زيادة حدة المنافسة: لقد غبرت العولمة حسدود المنافـسة، وتتضح هذه الصورة فى ظهور منافسين جدد

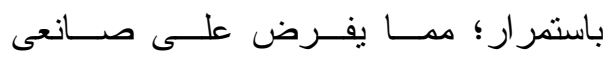

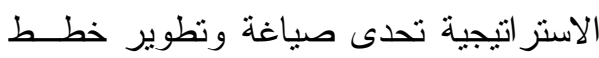
استر اتيجية كفو عة، وبعيدة المــدى لمعالجــة وضع منظماتهم.

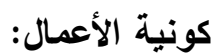
لقد تلاشت فى عالم الأعمــال حــدود السيادة بين الدول و الأقاليم، وذللك مع زيــادة الاعتماد المتبادل للاقتصادات، وندرة المو ارد الطبيعية، كل هذه المعطيات، و غيرها جعلت (ץ) د.رضا خلاصى، موج الإدارة الاستراتيجية،

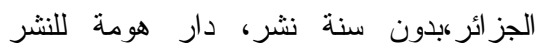

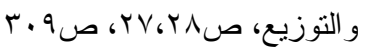


المستهدفة و أسلوب المنافسة وســبل تحقبــق

النقلة النوعية. (0)

مبررات التخطيط الاستر اتيجي:

قبل المضي قُمًا في شر ح الوظــائف

الأساسية التي تتم في هذه المرحلة، لابد من

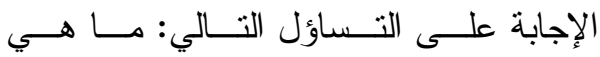

المبرر ات التي تؤدي إلى أن تفكر المؤسـسـة

بالشروع في عملية التخطيط الاســنزاتيجي؟

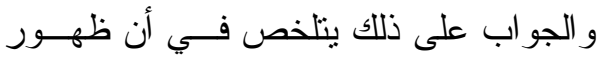

واحدة أو أكثز من المو اقف التاليــة بـــؤدي

بالمؤسسة إلى التفكير بالتخطيط استر اتيجيًّا:

ا ـ اكتثاف أخطاء في عمـلـ المؤسـسـة:

وتتمنل هذه الأخطاء في الإخفــاق فـي

الوصول إلى نتائج متطابقة مع الأهداف

$$
\text { الموضو عة. }
$$

r. تبلور فجــوة ملقتــة للنظــر فــي أداء

المؤسسة: وذللك عندما تــصبح نتــائج

الأداء تبتعد كثيرًا عن التوقعات، أو عن

تلك العائدة للمؤسسات المنافسة.

r. تولي مدير عـــام جديـــ لمهامـــه فـي

المؤسسة: إن المعتاد في عالم الإدارة أن

لكل مدير عام أسلوبه وطريقته الخاصـــة

به في قيادة المؤسسة. فالمدير العام ليس

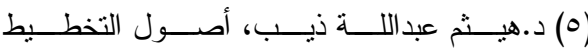

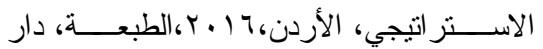

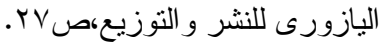

\section{ب - تطور مفهوم الإدارة الاستراتيجية:}

فى البداية كانت الادارة الاستراتيجية

تــستخدم فقــط فــى المؤســــات الكبــرى

و الثركات متعددة الجنــسيات مــع زيـــادة

مخاطر الأخطاء كأخطاء التكلفة فقد جعلــــ كل المديرين المتخصصين و المحترفين فـى كل الهيئات أو المؤسسات تأخذ نظـــم الإدارة الاستر اتيجية بجدية حتـى تحــتفظ لنفـسها بالقدرة على المنافسة مع المؤسسات الاخرى المشئهة (ع)

وترجع جـذور الاســنز اتيجية إلـى

الأصل الإغريقى، التى تعنى (فن الحـرب)، ونقل هذا المصطلح إلى حقل الإدارة، ويعنى (فن الإدارة أو القيادة)، وقد بدأ تطبيق مفهوم الاستر اتيجية فى ميدان الأعمال عــام 1901 عندما أشار "نيومان" إلى أهمية الاستر اتيجية فى التخطيط للمشروع الاقته صادى، وفــى الستينيات وضعت الأسس الرئيسة لمفهـوم

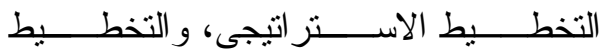
الاستر اتيجي هو تخطيط بعيد المدى بأخذ في

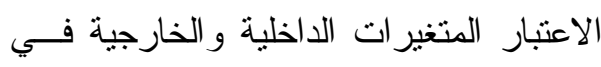
المنظمـــات ويحــدد القطاعــات و الــثر ائح language of Strategic management. Journal Management Development, 28 (1): 6-17 
طبيعة التغير ات السريعة فى البيئة المحيطـــة من حولنا . (v) مستويات الإدارة الاستر اتيجية تتكون الإدارة الاستر اتيجية من ثلاثـــة

$$
\text { مستويات، هى: }
$$

- الإدارة الاستر اتيجية للمنظمة: فى هــــان المستوى، تتولى الإدارة الاســنر اتيجية

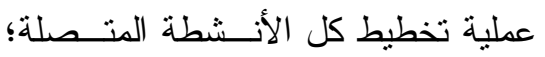

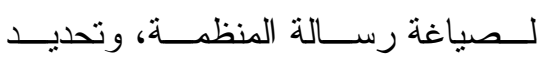
الأهداف الاستر اتيجية، وحشد المـــوارد اللازمة، وصياغة الخطة الاستر اتيجية. - الإدارة الاســـتراتيجية فــى مسـستوى وحدات الأعمال الاستراتيجية: تتــولى الاسلى الإدارة الاستر اتيجية فى هذا المسستوى، صياغة وتتفيـــ الخطـــة الاســـر اتيجية الخاصة بكل وحدات الأعمال.

- الإدارة الاســتر اتيجية فـــ المـــتوى

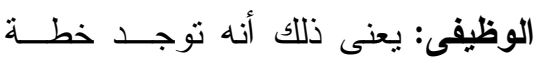
استر اتيجية للتسويق، وخطة استر اتيجية للأفر اد، وخطة للإنتاج؛ حيث تتولى كل

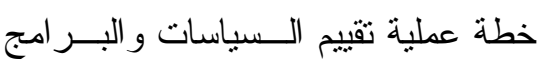

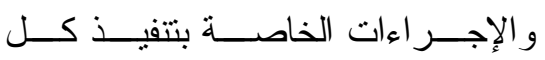

$$
\text { وظيفة. }
$$

(7) French S. 2009. Re-framing strategic thinking: the research - aims and outcomes. Journal of Management Development, 28(3): 205-224
موظفًا عاديًا في مؤسسته، فهــو يتمتهـع

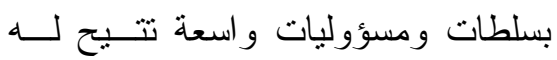
تغيير معالم العمل المؤسسي للوجهة التي

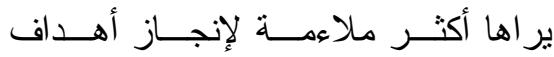
مؤسسته.

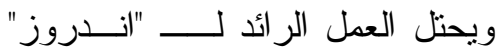
مكانة بــارزة فـى تـشكيل حقـلـ الإدارة الاستر اتيجية. وفى بداية عقــد التـسعينيات ظهرت مفاهيم جديدة، منل مفهوم الكفــاءة المحورية، و المنافسة على القدر ات، ومدخل

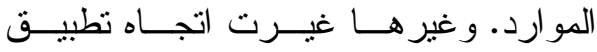
استر اتيجيات الأعمال من خلال التركيز على المهار ات و المو ارد التنظيمية، وعلى كفــاءة الإدارة فى إدارة وتوجيه الموارد، و اذا كانت عملية صياغة الاستر اتيجية مهمة صعبة فان تطبيقها بصورة ناجحة تمنل الكثر صــعوبة بمعنــى ان فــشل الإدارة فــي تطبيــق الاستر اتيجية يعنى فنثل الدارة ككل (؟). و هناك ثلاث نقاط عالية الاهمية يمكن اكتسابها من الادارة الاستر اتيجية هى : 1 -

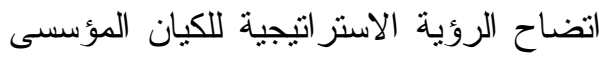

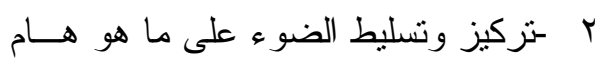

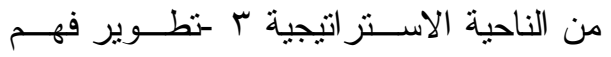

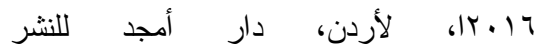

و التوزيع، 119 11 
ولتجاوز عناصر الضعف الموجـودة فــى النموذج، هناك محددات يجب فهمها، وهي

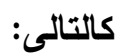

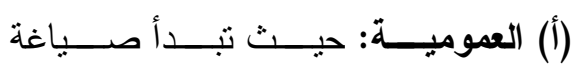

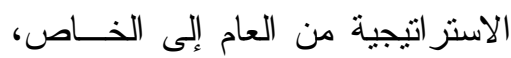

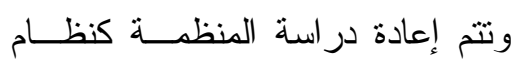
متكامل، يعمل فى سياق بيئة محددة، إعلة

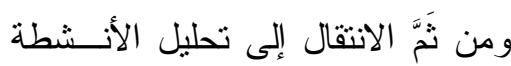
التتفيذية للأنظمة الفرعية. (ب) التحليلية: يُعتبر النموذج تحليليًا أكثر

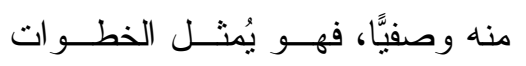

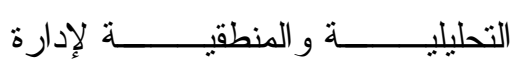

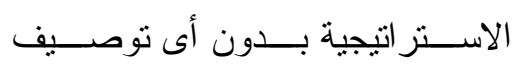

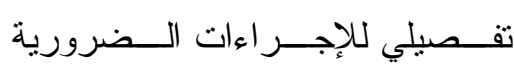

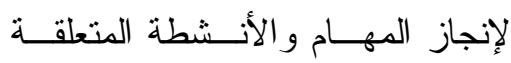
بكل مرحلة رئيسـية مسن مراحـل

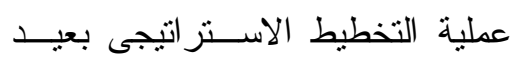
المدى.

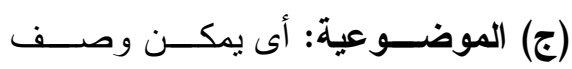

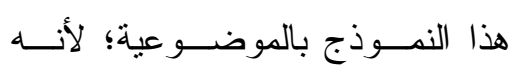
يرتكز على تحليل عناصر ومتغيرات

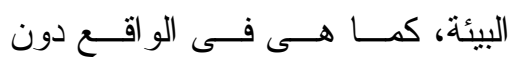
إضمافة.

1 -عمليات الإدارة الاستر اتيجية:

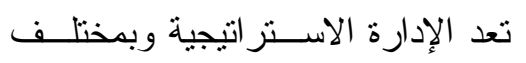

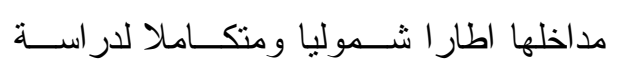
وتحليل كل الأنشطة و العمليات ضمن اطــار
ه - نموذج عملية الإدارة الاستراتيجية:

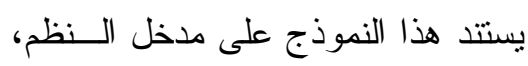

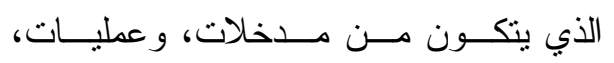
ومخرجات، وتغذية عكسية، ومدخلات النظام

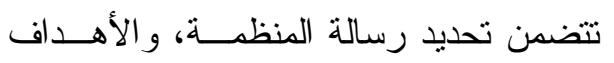
الاستر اتيجية، و المعلومات التى تتـتنج عـنـن

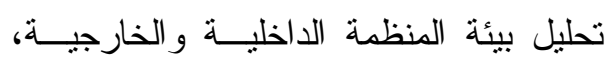
ومرحلة العمليات تتضمن تحليـلـل عناصــر

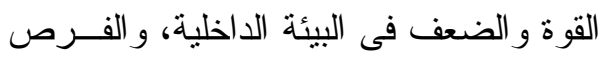

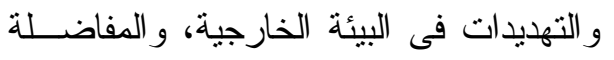

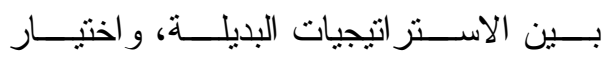

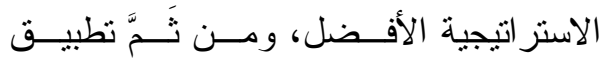

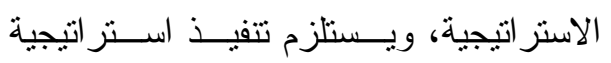

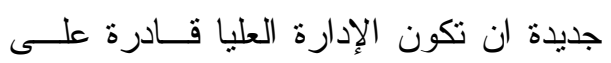
تحقيق إمكانية تجاوز حالات عــدم الاتفــاق وبناء الاجماع. (^). أمَّا المخرجات فنتنمل على: عمليــة تقييم النتائج، النى تمخضت عن تنفيذ الخطة

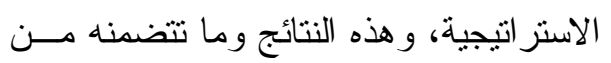

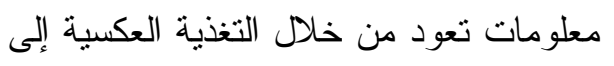
عنصر المدخلات، و هذا العنــصر (التغذيــة معنة

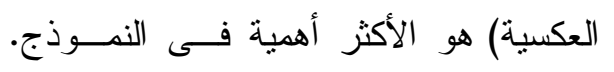
(1) د.أثمار عبد الر اذق، استراتيجية التكامل و إعادة

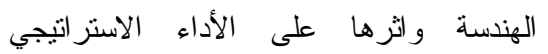

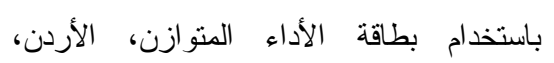

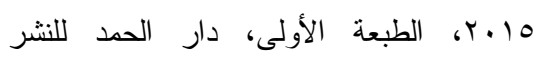
و التوزيع،صبr. الطبع. 


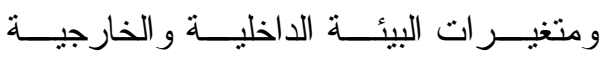
للمنظمة، بنفس القــدر تكـــون الإدارة أمسـام فرصة النجاح فى تصميم وتطبيق استر اتيجية

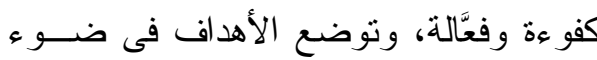
عدة عو امل ، منها: - علاقات التـأثثير و التــأثز بــين البيئــة الخارجية والبيئة الداخلية للمنظمة.

$$
\text { - كمية ونوعية الموارد المتاحة. }
$$

- القدرة على تحقيق الموازنة بين المنظمة

$$
\text { و البيئة. }
$$

- مثقافة وقيم الإدارة العليا.

- علاقات السلطة و المسؤولية و الصلاحية بين أفراد التنظيم.

$$
\text { - أسلوب اتخاذ القرارات الإدارية. }
$$

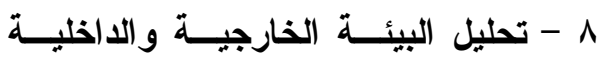

\section{للمنظمة:}

\section{تحليل البيئة الخارجية غير المباثرة:}

يُقصد بذلك عملية استكثناف العو امـلـل

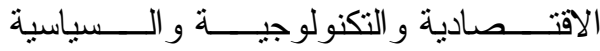

و الاجتماعية و الثقافية، وذلك من أجل تحديــد

الفرص و التهـيــــات الموجـــودة فــى بيئـــة

المنظمة الخارجية، ، فتحليل البيئة الخارجية يُساعد الإدارة فى تكوين نظام للإنذار المبكر

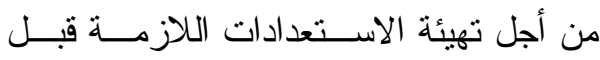

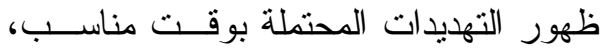
ويتعلق التحليل الاستراتيجي من وجهة نظر

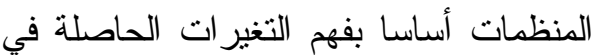

المنظمــة(9)، ان صـــياغة رؤيسـة ورســالة المنظمة هي فكرة عامة مجردة قريبــة مــن

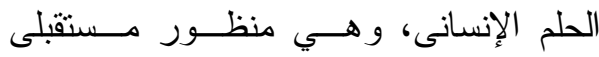
للإدارة، و العاملين فيها، تتضمن -عــادة أكثر المعانى اتساعًا، أمَّا رسالة المنظمة فهى تلهي الفرض الأساسى، الذي وجدت مــن أجلــهـ المنظمة، أو المهمة الجوهرية لها، ومبــرر وجودها و استمر ار ها، وهي توصيف أكثـر

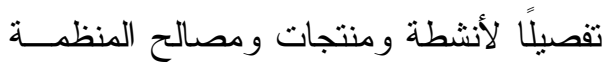
وقيمها الأساسية. ولكل منظمة رســالة خاصــة بهــا، وتختلف هذه الرسالة بــاختلاف المنظمـات، وفى ضو ء رسالة المنظمة يتم تحديد الأهداف

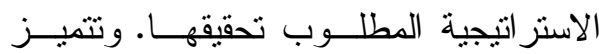
الرسالة بالثبات النسبى على خلاف الأهداف،

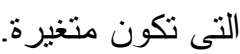
V

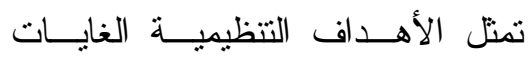
و النهايات، التى تسعى الإدارة إلى الوصـــل لهـل

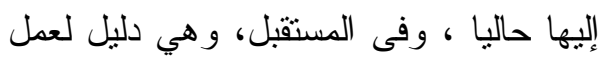

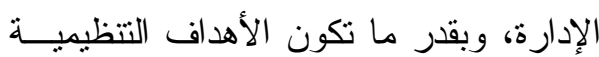
و اقعية، ومعبرة بصورة صحيحة عن قــوى الإنى (9) د.ثائر شاكر محمود الهيتى، د. سامى ذياب

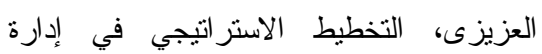

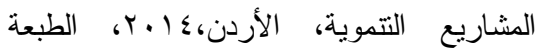

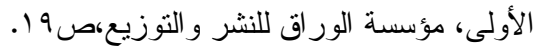


ولأن الأفراد هم بالدرجة الأولى جزء مــن النسيج الاجتماعى و الثقافى، الذي تتواجد الأديه

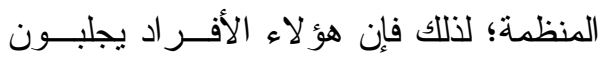

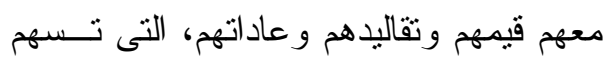
فى التأثنر بالثقافة التنظيمية. 9 - صياغة الاستر اتيجية علــى مسستوى

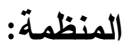

إن الخطوة الأولى فى صياغة الخطــــــة الاستر اتيجية على مسنوى المنظمة، هو فـى في أنى

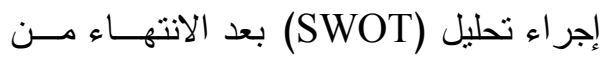
عمليات تحليل وتثخيص العوامل الحيويــة

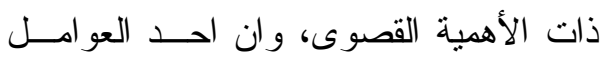
المهمة والاساسية هي فهم المناقسة لغــرض الهـ صياغة استر اتيجية فعالة للمنظمة ('). تطبيق تحليل SWOT (تحليل عناصر القوة و الضعف و الفرص و التهيدات): تحليل SWOT: هو أداة مفيدة لتحليل الوضع العام للمنظمة على أســاس عناصــر

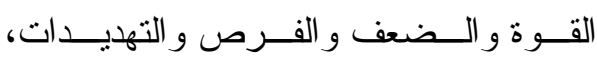

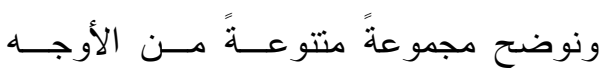

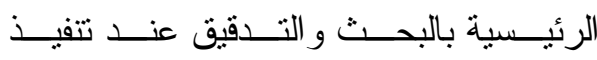
مدخل SWOTفى التحليل:

(1)(1.د.طل محمد الججاوى، ساكنة السلطانى،

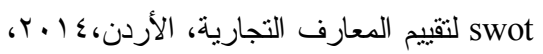

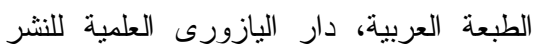

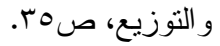

البيئة الخارجية ومدى تاثير ها فـــي فعاليــات

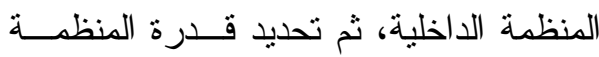
على استغلال مو اردها وتحديد افضل الــسبل

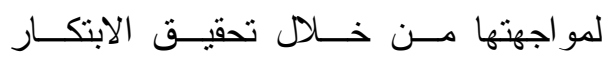
و التميز (1.) تحليل البيئة الداخلية للمنظمة: يُطلق بعض الكتّاب على عملية تحليل البيئة الداخلية، تحليل الميـزة الاســـنز اتيجية للمنظمة، و الميزة الاستر اتيجة تعنى عمليــة

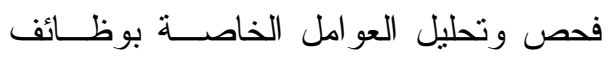

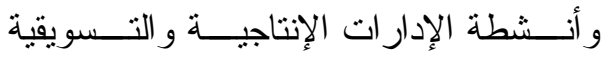

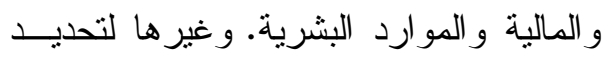

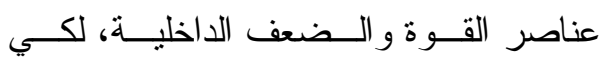
تسنطيع المنظمة أن تعمل بأقـــى كفــــاءة

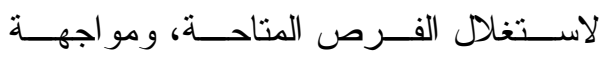
التهديدات فى البيئة الخارجية. تحليل الثقافة التنظيمية:

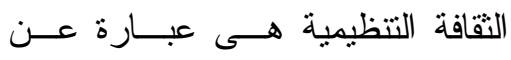

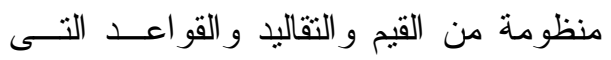

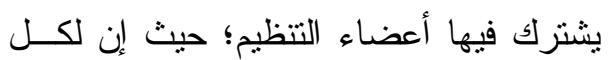

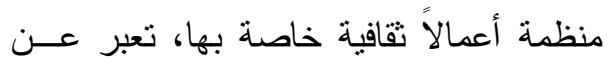

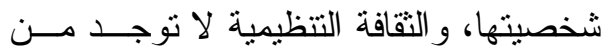

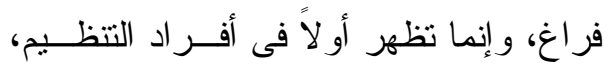

(·) (1).د.امر البكرى،د.احمد الصقال، التحليل الاستر اتيجي و الميزة التتافسية، الأردن، 17 . r،

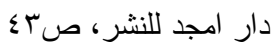


وفن تحقيق الغايات العُليا باســتخدام الأمثـلـل للمو ارد و الإمكانيات المُتّاحة.

ولم تتبلــور مكونــات الاســتر اتيجية

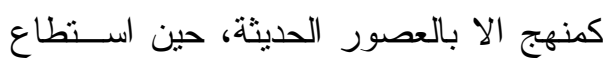

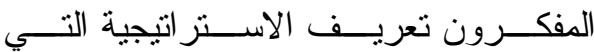
اخضعت لها فيما بعد تطوير كـلـ مكونــات قوى الامة من خلال خطط استر اتيجية بعيدة

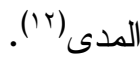

فتطوير وتكامل الخطة الاســتر اتيجية تهدف الى الوصول الــى انجــاح قطاعـات

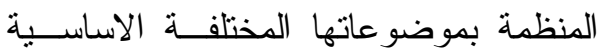

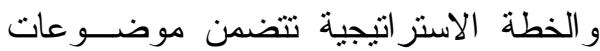

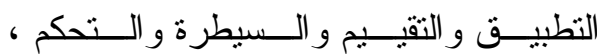

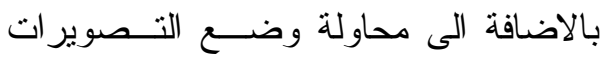

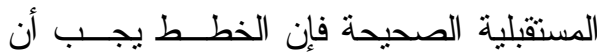
يكون فيها مرونة الحساسية للتغير ات بمكـن

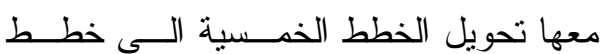

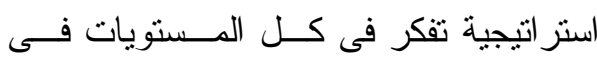

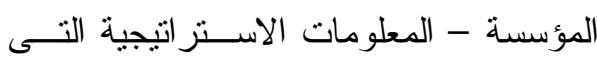

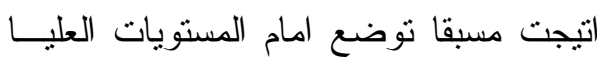
يكون مصدر ها شبكة محلية للمعلومات خلال

(Y) د د.متعب الزبن، البناء الاستراتيجي للدولة الإسلامية في عهر الخليفة عمر بن الخطاب الابناء وتقويمها في ضوء مبادئ الإدارة، الأردن،

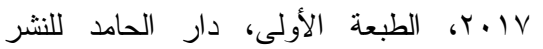
و التوزيع، صلانول
- عناصر القوة في المنظمــات: تتمثـلـل بصورة جوهرية باقتدار وكفاءة التنظيم،

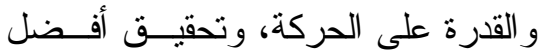
الإنجاز ات الصناعية الاقتصادية.

- عناصر الضعف: تعنى ضعف القــدرة

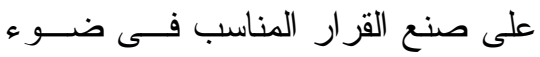
تحليل إمكانيات ومو ارد المنظمة. - التهديدات: هى الأحـــاث المحتملـــة، و المعقولة، التى إذا ما ظهـرت تــسبب الده ضررًا حقيقيًا للمنظمة. - الفرص: هى وقائع موجودة فى مكــان

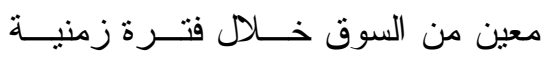

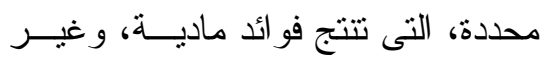

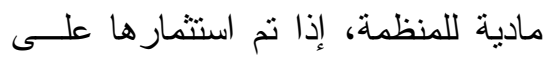
الوجه الصحيح.

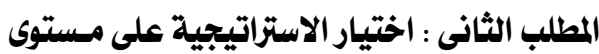

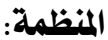

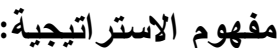

نشأ اصطلاح الاستر اتيجية فى رحاب الأدب العسكرى، فالقو اميس العسكرية تعرف هذا الاصطلاح بأنه (فن القيادة، أو فن إدارة

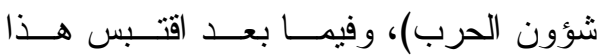
المفهوم، وظهر فى مجال التتصية الاقتصادية و الاجتماعية؛ حيث أصبح يطلق علــى فــن فئن إدارة شؤون التتمية الاقتصادية والاجتماعية،

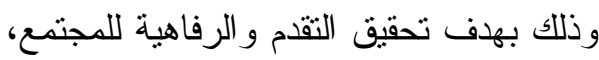

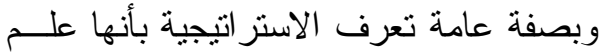




$$
\begin{aligned}
& \text { توجد عدة نمــاذج نظريــة لاختيــار } \\
& \text { المؤسسة وبدلا من مجموعة العمل المركزية }
\end{aligned}
$$

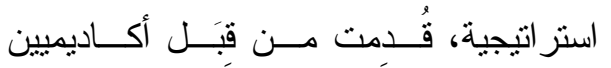

$$
\begin{aligned}
& \text { فى التخطبط فإن الاستشاريين مــن الخــارج }
\end{aligned}
$$

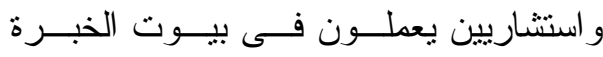

$$
\begin{aligned}
& \text { و المعلومات، ومن أهم هذه النماذج: } \\
& \text { نموذج بورتر للاستر اتيجيات العامة: }
\end{aligned}
$$

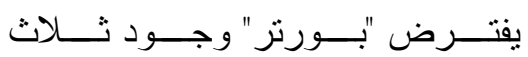

$$
\begin{aligned}
& \text { استر اتيجيات، يمكن أن تحقق المنظمات مــن } \\
& \text { خلالها ميزة تتافسية، وهي: } \\
& \text { استر اتيجية قيادة التكلفة: } \\
& \text { وهي الاستر اتيجية، التى تضع المنظمة }
\end{aligned}
$$

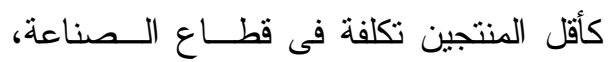

$$
\begin{aligned}
& \text { وذلك من خلال الاستتمار الأمتل للموارد. } \\
& \text { استر اتيجية التميز: }
\end{aligned}
$$

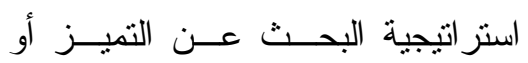

$$
\begin{aligned}
& \text { الانفر اد بخصائص استثنائية. } \\
& \text { استر اتيجية التركيز : }
\end{aligned}
$$

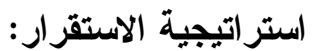




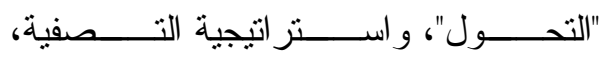

$$
\text { و الاستر اتيجيات المختلطة). }
$$

11 العلاقة بين صياغة وتطبيق الاستر اتيجية:

إذا كانت عملية صياغة الاسـتر اتيجية

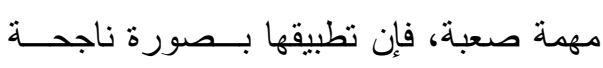

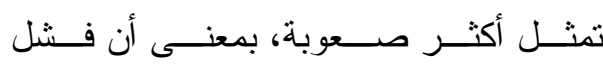

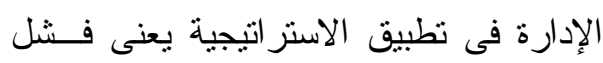

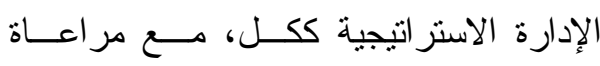

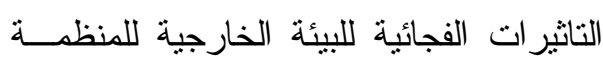

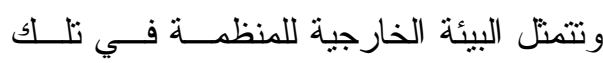

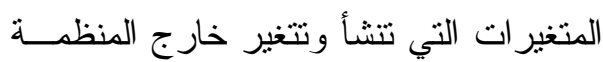

و التي تؤدى الى تغير حتمــى فـي مـسـار

المنظمة (10)

مستلزمات تطبيق استر اتيجية المنظمة:

بتكون نمــوذج نطبيــق اســتر اتيجية

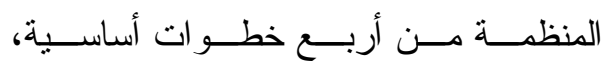

(الهيكل التتظيمى، والأنظمة الإداريــة

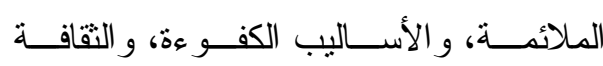

التتظيمية المنسجمة مع الاستر اتيجية).

(0).د. إسماعيل محمد السيد، الإدارة الاستر اتيجية،

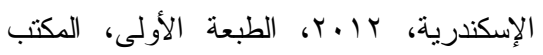

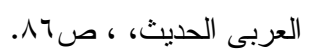

الاستثر ار، و وذذا يحدث عندما تكـــون الإدارة مقتتعة بالوضع الحالى للمنظمة.

وتتبع هذه الاستر اتيجية لعدة أسباب، منها:

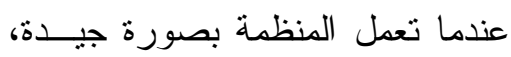

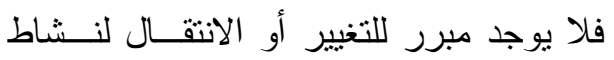

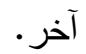

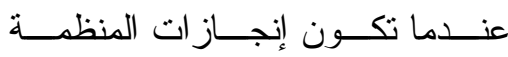

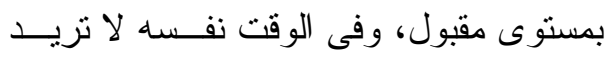

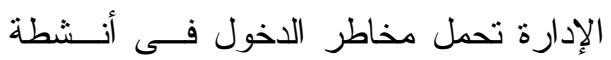

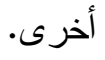

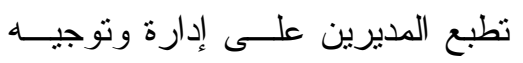

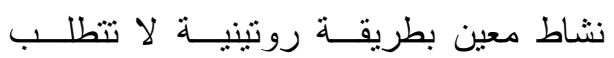
قر ار ات جديدة، أو تحمل مخاطر .

قلــــة المـــوارد المُتاحــــة للمنظمــــة،

وصعوبة الحــصول عليهــا مــن مــصادر الإقر اض و التمويل. الاستر اتيجيات الدفاعية:

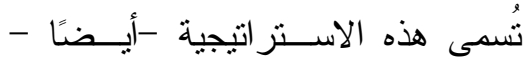

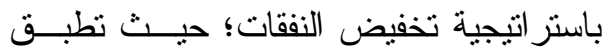

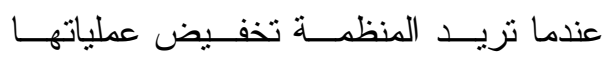
بصورة شاملة، وذللك من أجل إيقاف تدهور

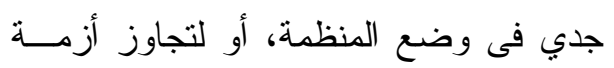
خطيرة تهدد وجودها، و استمر ارها فى ميدان

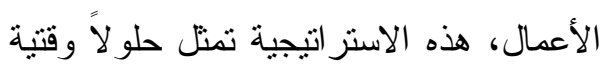

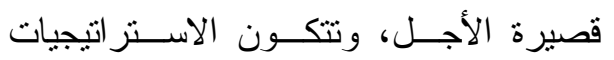
الدفاعية من: (استر اتيجية التثذيب "التخلص وله من بعض الأنشطة"، و استر اتيجية الانعطاف لئه لتسني 
مستقلتين لإنجاز أهداف مشتركة، و الــشكل الثائع للتحالف الاستر اتيجى هو المـشروع المـشترك، أى المــشاركة بــين منظمتـين

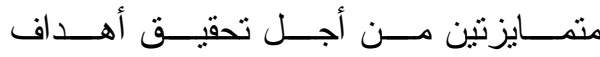
محددة. r ا أنظمة المعلومات الاستر اتيجية: تلعب أنظمة المعلومات الاســتر اتيجية دورًا مهمًا فى عمليات الإدارة الاســنز انيجية الخاصـــة بــصياغة وتطبيــق اســتر اتيجية الأعمال، وذلك من خلال ثنلاثــة مجــالات

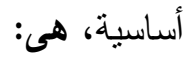
- تحسين الكفاءة التشغيلية التـى توفرهــا

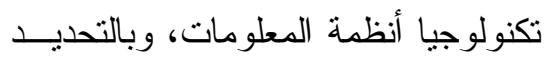

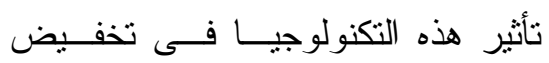

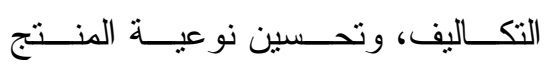

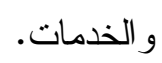
- تعزيز الإبداع التكنولوجى فــى ميــدان

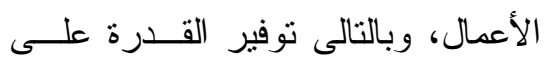
تصنيع منتجات جديدة. - بناء مصادر للمعلومسات الاســز اتيجية

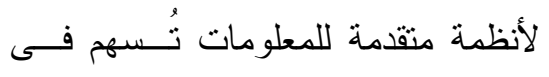
تحسين فعالية وكفاءة العمليات و الأنشطة الداخلية للمنظمة. - ـ وتعدد المعلومات تعتبــرمن العناصـر

\section{تحليل الهيكل التنظيمى:}

أثنتت الدراسات أنه يوجد تكامل بــين

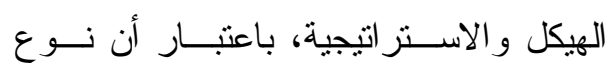
الهيكل التظظيمى المصمم، هو بمثابة المجال

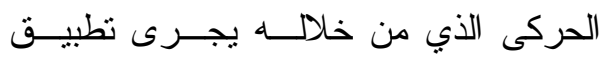
الاستر اتيجية. أثكال الهياكل التنظيمية، هى: الأشكال الهرمية للهيكل التظظيمى: هى

الهياكل الرئيسية الثائعة فى معظم المنظمات البسبطة، و المعقدة، صغيرة الحجم.

هيكل المصفوفة التظظيميـةة: يسـتلزم

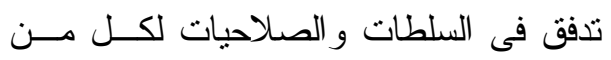

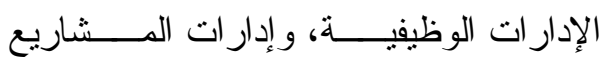
بصورة منوازنة فى التتظيم، ويستخدم هـــا الشكل لتسهيل عملية تطوير و إنجاز بــر امج وهي ومشاريع متعددة ومختلفة؛

هيكل الفريق التنظيمى: يستتـد هــذا

الهيكل على فكرة المشاركة فى السلطة بـين

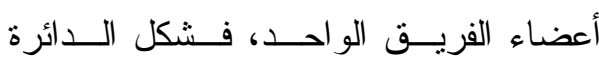
التتظيمية يشير إلى تساوى السلطة الموزعة بــين الأفــر اد، و المـشـاركة فــى الــسلطة

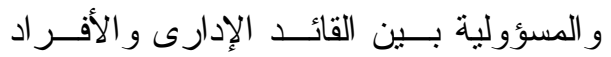

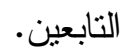

هيكل التحالف: يتطلب هــذا الهيكـل وجود تحالف اســتراتيجى بــين شـركتين 
تركيز و اهتمام الإدارة: اتجــاه التركيـز أو

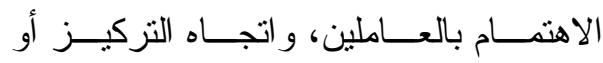

$$
\text { الاهتمام بالو اجب. }
$$

ـ 1 -عمليات الرقابة وتقييم استـتر اتيجية

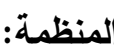

الرقابة، هى جهذ نظامى لوضع معايير

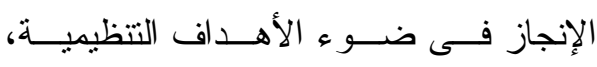

وتصميم أنظمة معلوماتية للتغذية العكـسية، ومقارنة الإنجاز الفعلى بالمعايير الموضوعة لمعله

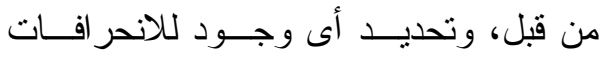

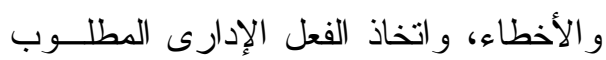

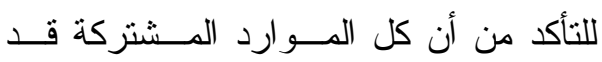
استخدمت بصورة كفو عة للغاية، وبطريقـــة فعَّلة لإنجاز الأهداف المشتركة. أولاً - الرقابة التقليدية: تصنف الرقابة التنظيمية تقليديًّا إلـى عدة مستويات، هى: الرقابــة الاســتر اتيجية

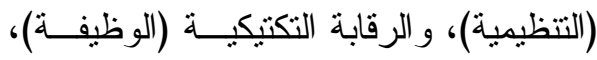
و الرقابة العملياتية. - الرقابة الاستراتيجية:

هى عملية ديناميكية مستمرة للسيطرة على استر اتيجية المنظمة من خلال تطبيــق

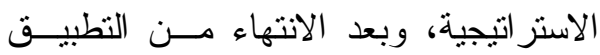
مباشرة، وهي وظيفة الإدارة العُليا.

\section{- الرقابة التكتيكية: - الرهية}

تعنى عملية السيطرة علـى عمليـات الإدار ات الوظيفية، مثل: الإنتاج، و التسويق، على على
الـــضرورية لاى عمـــلـ يقـــوم بــــة

الانسان (17). rأس أسلوب القيادة الإدارية:

يعنى الطريقة التى يؤثز بها المــدير/

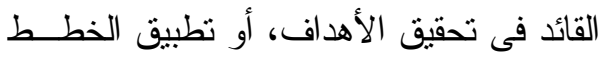
الاستر اتيجية، ويتكون أسلوب القيادة الإدارية من ثلاثة متغير ات متر ابطة، هــى: طريقــة

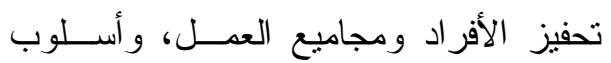
اتخاذ القرارات الإدارية، ومجالات التركيـز فى بيئة العمل. المتغير الأول: بالنسبة للتحفيز يمكن أن

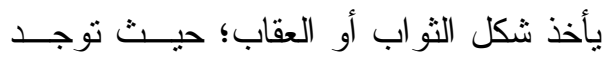
إدار ات تستتد على أسلوب التحفيز الإيجابى.

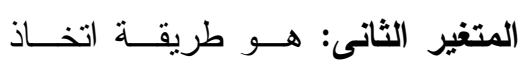

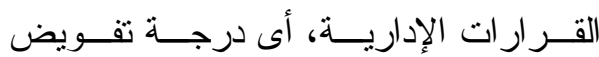
صلاحيات اتخاذ القرارات، ودرجة المشاركة للأفر اد العاملين فى عملية صنع القرار . المتغير الثالث: يتعلق بالمنظور، الذي

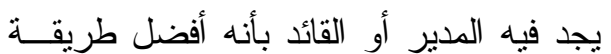
لجعل الأفــر اد ينجـزون العهــل بــصورة مرضية، ويوجد اتجاهان رئيسيان بخصوص

(7 (1) د.ليث عبداللة القهيوى،د.زياد كامل الالا،د.بلال محمدد الرادى،ودة المعلومات و والذكاء الاستر اتيجي في بناء

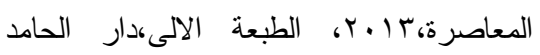

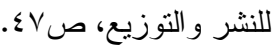


ومكان الخلل، ومعالجته فى أى مرحلة مـن مر احل دورة حياة النظام الإنتاجى. ثانيًا -الاستر اتيجية و الرقابة:

تعنى عمليـات الـسيطرة التتظيميــة

المستمرة على تطبيق اســنز اتيجية المنظمـــة بصورة كفو ءة وفعَّلة، وبما يضمن تحقيــق رسالة المنظمة والأهداف الاستر اتيجية. وتم

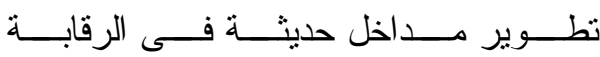
الاستر اتيجية، أهمها: المدخل الناقد، أو نظام

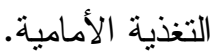
ويتكون هذا النظام مـن الخطــوات التهـون

التالية: السيطرة على المقدمات المنطقيــة

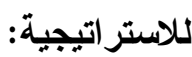

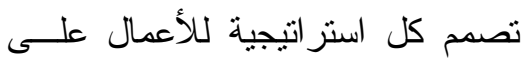

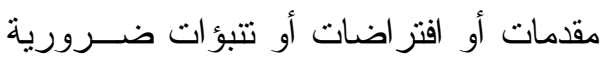
لعملية التخطيط؛ لذلك فى هذه المرحلة تــتم

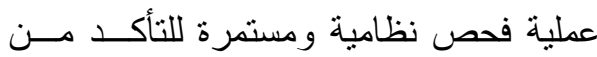
صحة هذه المقدمات خلال مرحلتى صــياغة وتطبيق الاستر اتيجية، وان مفهــوم اليقظـــة

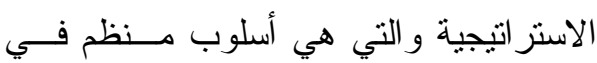

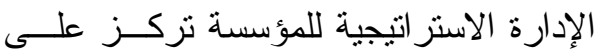
تحسين منافستها (IV) - الرقابة على التطبيق: تتضمن عملية الرقابة فى هذه المرحلة

د.رضا خلاصى، مروج الإدارة

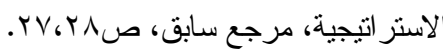

و الافر اد، و المالية. وغير ها؛ للتأكد مــن أن

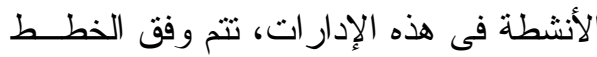
الوظيفية الموضو عة لها. - الرقابة العملياتية:

هى عملية السيطرة والرقابة الروتينية

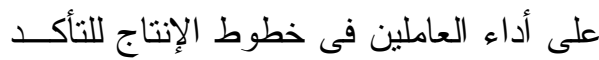
من تتفيذهم للمهام و الو اجبات المحددة ســلفًا

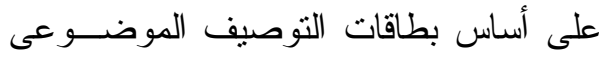
للعمل أو الوظيفة.

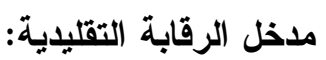
يُطلق على المدخل -أيــضـا - -نظــام التغذية العكسية، الذي يتكون من الخطـــوط التالية: 1 المعاييز: هى مقاييس دقيقة ومحسددة

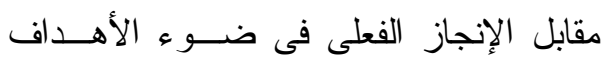
التتظيمية، ومفردات التوصيف الوظيفى. r - بياس الإنجاز الفعلى: هى عملية تحديد النتائج المتحققة عـن النئن

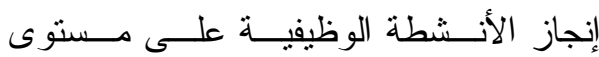
الإدار ات الوظيفية و الو اجبات و المهمات. r - مقارنة الإججاز الفعلى بالمعايير: الهدف من هذه المقارنة هو التوصيف الدقيق للانحر اف، والأخطاء التى حصلت فى عملية الإنجاز . ؛ - تصحيح الأخطاء وتعديل الاتحر افات:

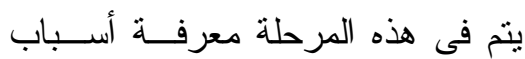




$$
\text { r) بأين نريد أن نصل؟ كيف يجب أن نصل؟ }
$$

10

لقد ظهر تعبير التتمية المستدامة بين

بداية ومنتــصف الثمانينيــات مــن القــرن

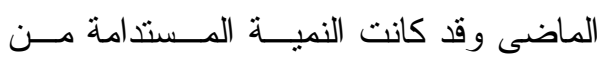

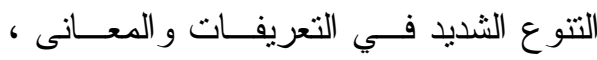

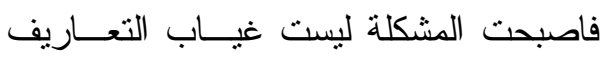

و انما تعددها وتتو عها ('^).

لذلك تجلت أهمية أنظمة التكنولوجيــا

الحديثة لحفظ هذا الكم الهائل من المعلومات و المعارف لخمة اهداف التتمية المستدامة، و تلعب أنظمة المعلومات الاســتر اتيجية دورًا مهمًا فـى عمليـات الإدارة الاســترانيجية الخاصـــة بــصياغة وتطبيــق اســتر اتيجية الأعمال، وذلك من خلال ثلاثـة مجــالات أساسية، هى: - (الاعمال، ودن

- تحسين الكفاءة التشغيلية، التى توفرهـــا تكنولوجيا أنظمة المعلومات، وبالتحديد

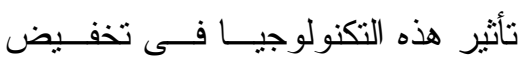

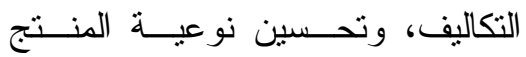

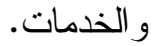

د.مصطفى يوسف كامى، التخطيط و النتمية

من منظور (اقتصادى،بيئى، اعلامى) الاردن،

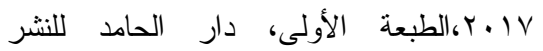

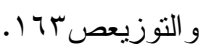

تحديد وتقييم الأحداث و العو امل ذات الأهمية الحيوية للمنظمة، التى لم تؤخذ بعين الاعتبار خلال عملية صياغة الاستر اتيجية. وفى هذه المرحلة يتم سد الفجوة بــين مرحلتى صـــاغة وتطبيــق الاســنز اتيجية،

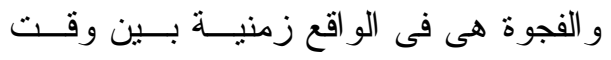

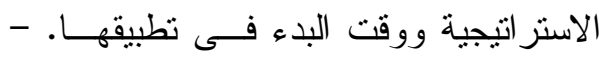
الإشر اف الاستر اتيجى:

و هو ذو طبيعة عامة وغير محددة، لا لانئل

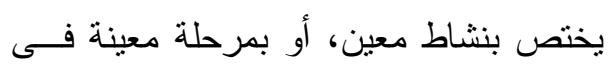
حياة الاستر اتيجية، فهو يمتل منظورًا رقابيَّـا

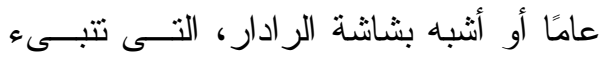

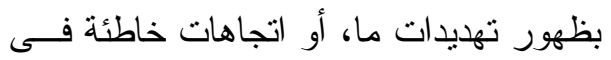

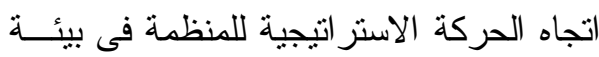

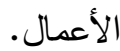
ثالثًا -مستويات عمليــة مراجعـة وتقيــيم الاست

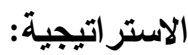
تهنم الإدارة الاستر اتيجية بتقييم الأداء الكلـــى للمنظمــــة مــن خـــلال مر اجعــة الاستر اتيجية لأداء المنظمة ككل، وبيان مدى لأل النجاح الذي حققته استراتيجية المنظمة على لاهل تحسين الأداء، بالإضافة إلى مر اجعة وتقيــيم

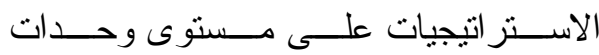

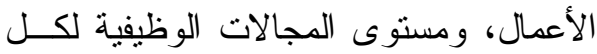
وحدة استر اتيجية. ومن الــضرورى إعــادة طرح الاسئلة النوعية الثلاثة التالية: ( ) أين نحن الآن؟ 


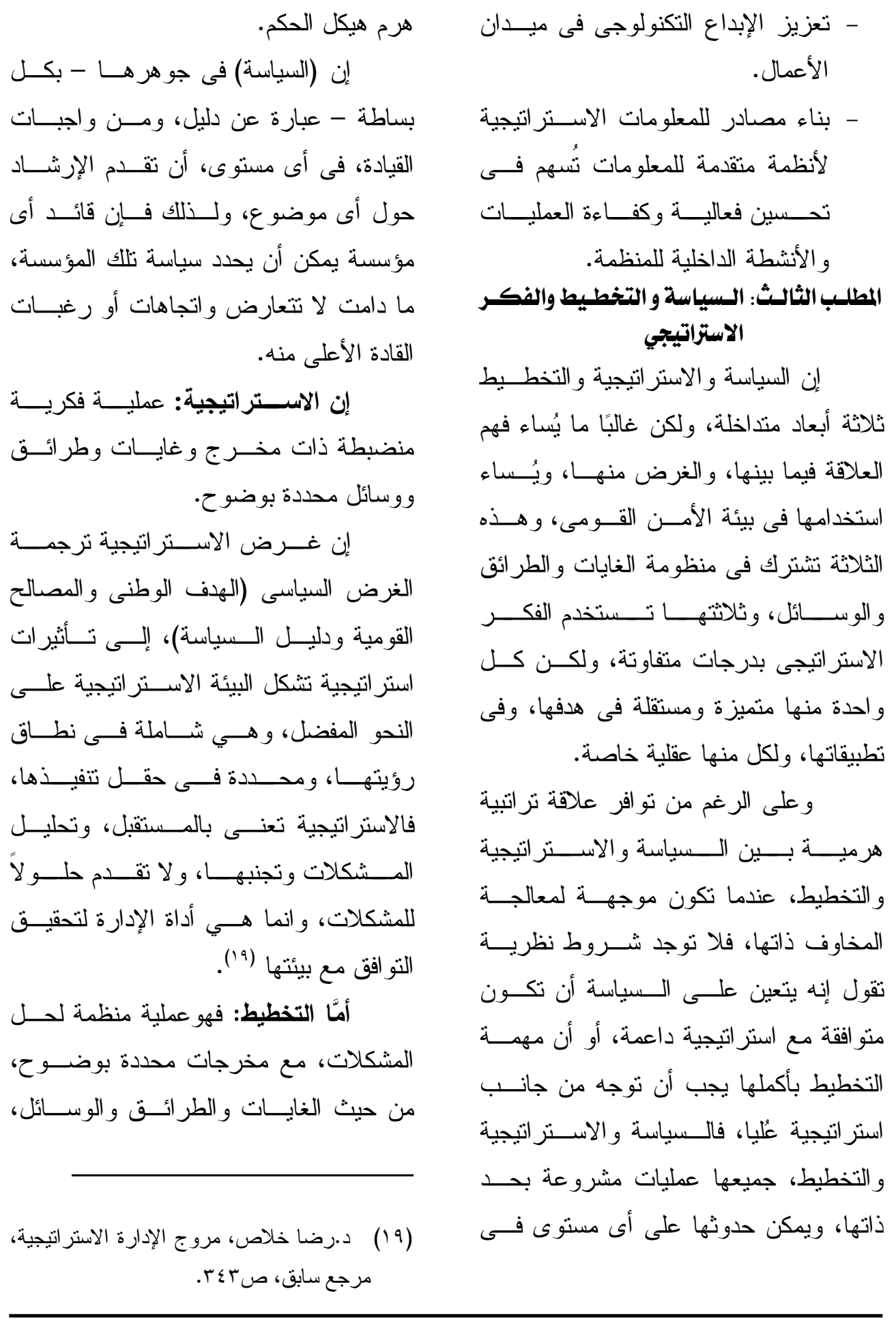


وتتحــــث الاســـتر اتيجية و الخطـــــ اهـ

الموجودة عن عملية إعــادة التقـــويم هــذه،

وقد تتم المواققة على الخطـــ أو تعــديلها؛

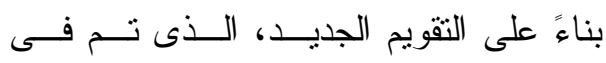

الوقت الفعلى للحادثـــة إذا كانـــت الحادثــة

خطيرة بدرجة كافية فقد تتطلب إعادة تقــويم

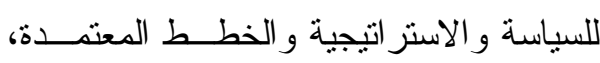

لكى نرى ما إذا كان التغيير، الــذى ســبيته

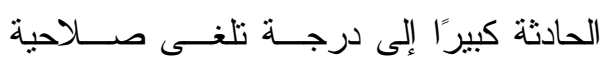

الخطط الموجودة، أو تفرض إخخال تعديلات عليها.

ويحتاج المخططون إلى فهم نظريـــة

الاستر اتيجة و الفكر الاســتر اتيجى، بحيــث يستطيعون تطبيق السياسة و الاســتراتيجية، كما يحتاجون إلى فهم انعكـــات توصــيات قرار التخطيط، عند إعمال معالجة الأزمـــة، أو عندما يقومون بالتخطيط لقضية مباثــرة من صلب السياسة.

أمَّا التفكير الاستراتيجى: فهــو فـى معناه الجوهرى بعنى القدرة علــى تطبيــق نظرية الاستر اتيجية فى العالم الواقعى، ثـــ

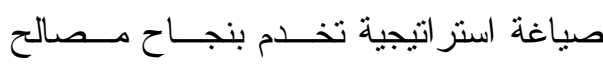
محددة للاولة المعنية، من دون تحمل مخاطر يمكن تفاديها، وتتمنل فى خلق عواقب سلبية على مصالح أخرى للدولة ذاتهـــا، و الفكــر

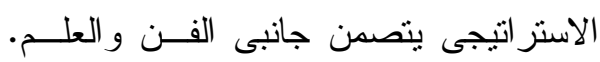
و هذا يتيح لمن يمتلك هذا الفكر خلق توليفــة
ويسعى التخطيط إلى خلق طمأنينة من خلال تحليل جميع المتغير ات ذات الصلة الموجودة فى البيئة المحيطة، وتحديد علاقات الـسبب و النتيجة بين هذه المتغير ات.

ويمكن للتخطيط أن يكون قصير الأمد

أو طويله، فالخطة الطويلة الأمد، التى تغطى عامًا لا نحكم عليها بأنها غير منسجمة (Y. ) مع منطق التخطيط، مادامت المؤسسة التـى وضعت الخطة لديها رؤية و اضحة للمستقبل، وتستطيع التتبؤ بالمشكلات التــى يمكـنـ أن وتن تو اجه8ا.

لذلك فإن صياغة الاستر اتيجية خطوة

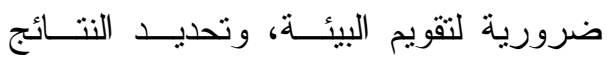
الضرورية للنجاح، ومن ثَثَّ الإعـــلن عــن الغايات و الطر ائق و الوسائل المناسبة، التـى

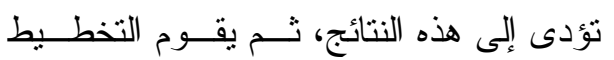
بتظوير منظومته الخاصـــة مــن الغايــات و الطر ائق و الوسائل الثانوية بشكل تقـــيلى، التى تؤدى إلى تحقيق أهداف الاستر اتيجية.

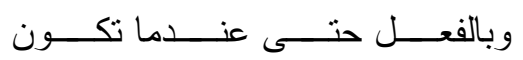
الاستر اتيجية و الخطط الداعمة الموجودة قبل الحادثة الطارئة قد نتبأت بــبعض الحـــو ادث المحتملة، فان الحكومة ســتقوم بــالتخطيط لمعالجة الأزمة؛ لأن الأحداث الجسيمة على أرض الو اقع بحاجة إلى أن يُعــاد تقويمهـــا

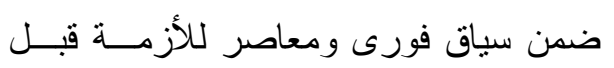

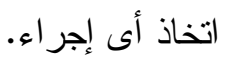


الآر اء وافتعال التقاطعات لتوسـيـع عمليــة

$$
\text { التفكير (r.). }
$$

وفى البرامج التعليمية لكبار ضــباط

الجيش الأمريكى و المــسؤولين الحكـــوميين

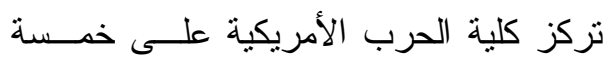

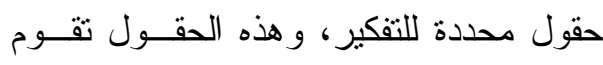
بدور العدسات المكبرة؛ لتقدير تحديات البيئة الاستر اتيجية، وتقويم أبعادها، وتحديد طر ائق

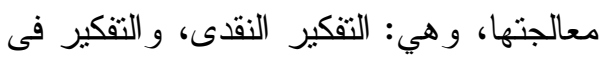
التأثنر المتبادل بين المنظومات، و التفكير فى وهي

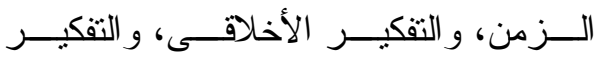

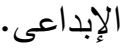

إن (التفكير النقلى) بوصفه كفــاءة،

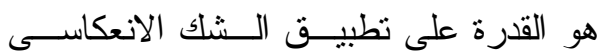

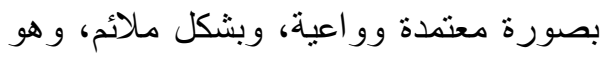

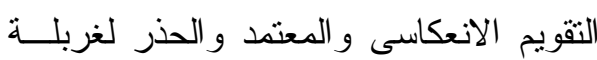
المعلومات؛ بقصد تحسين أحكام المرء، و هو

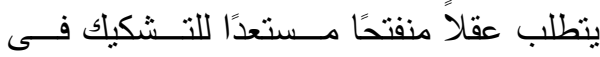
المقو لات التقليدية، ونقدها، و أن يكون مستعدًا

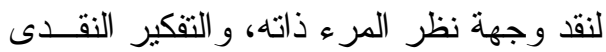

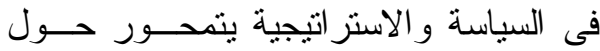
عمق التفكير و اتساعه، والحيادية، ونوعيــة الخيار ات المُتاحة، و إمكانية تطبيقها. (·r)(اد.ذكريا الدورى،د.احمد على صالح، الفكر

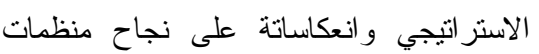
الاعمال، الأردن، 9. ..ب، الطبعة العربية، دار

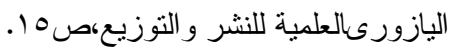

تجمع حسابات التقلب و التـــوجس و التعقيـــــ

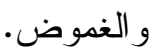
وأخيرًا يقوم بصياغة النص المعقول

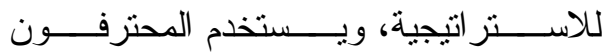
المتخصصون فى الأمن القومى، و العــاملون

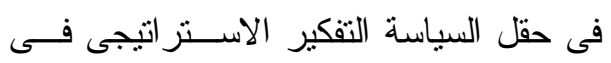
عملهم اليومى فى أثناء صـــياغة الــسياسة،

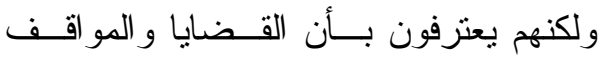
الأكثر صعوبة وتعقيدًا وذات الأمد الاطـــول تتطلب من السياسة التحـــول إلــى صــباغة مباثرة لــ (استر اتيجية).

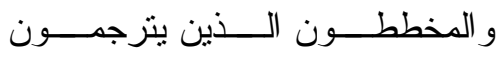
الاستر اتيجية إلى خطط و عمليــات محسـددة

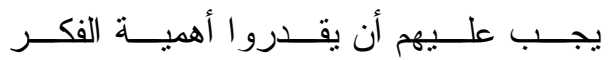
الاستر اتيجى لكي يسنطيعوا التخطيط بـشكل سليم، و التكيف عند الضرورة و إدر الك عوامل الضن النجاح أو الفنشل؛ حيث يُساعد المنظرون فــى

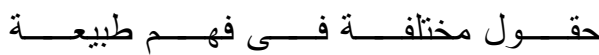
التفكير الاستر اتيجى، و الكفـــاءات اللازمـــة للتفكيــر بطريقــة اســتر اتيجية، ونظريــــة الاستر اتيجية. ان بناء السيناريوهات يستلزم تفعيـلـل المشاركة الجماعية في الآر اء و المقترحسات

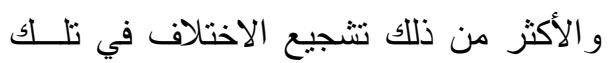


المشكلات و المو اقف المألوفة و الروتينية فإن

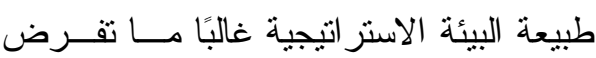
مو اقف ذات نهايات مفتوحة.

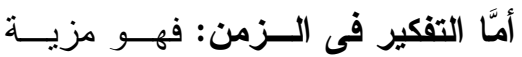
مرتبطة بالفكر لفه دور العو امل المسستمرة

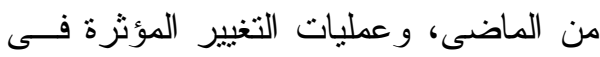
تشكيل المستقبل، أى القدرة على رؤية الزمن

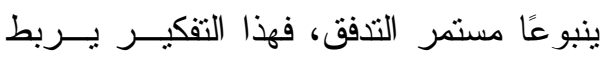

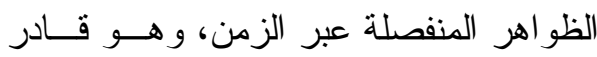
على إيجاد الروابط، مع خيار ات وظــروف مستقبلية محتملة للوصــول إلــى المسـنقبل

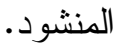

أمَّا التفكير الأخلاقى: فهو أحد العو امل المهمة فى صياغة السياسة والاســتر اتيجية، و هو يؤثز مباشرة فى نجاحها، وهذا ينطبـتق

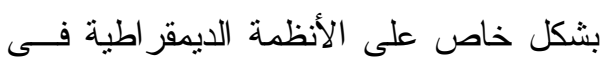

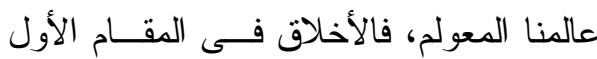
تصنف السلوك البشرى ضمن ثلاثة أنماط: (1) سلوك إجبارى: "ما يجب على المرء

$$
\text { فعله". }
$$

(Y) سلوك محظور: "ما يحرَّم فعله"

(r) سلوك مُباح: "ما يمكن للمر ء فعله".

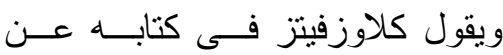

الحرب "إن النظرية، وبالتبعية الاسترانتجية، تزداد تعقيدًا بلا حدود حالما تلامـس حقـلـل القيم الأخلاقية".
إن التفكير فى التأثير المتبــادل بـين المنظومات مكون أساسى آخر فى التفكيــر

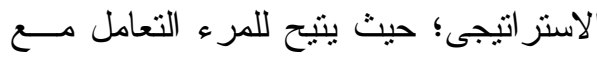

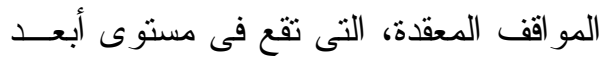
من علاقة السبب و النتيجة، ومـــع أن هنــاك

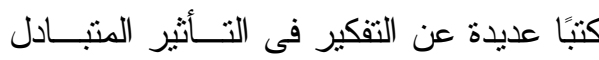
بين المنظومات، فإن الميزة الجوهرية فيـهـ هى القدرة على رؤية أجز ائها،.

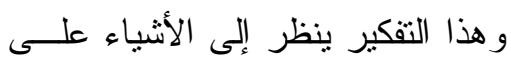

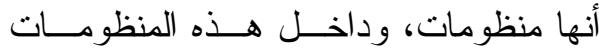
تتفاعل الأجزاء و التأثيرات. ويتمنل التفكيــر

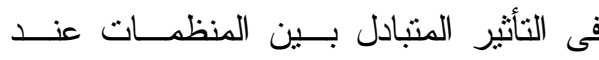
صناعة السياسة والاستر اتيجية فــى القــدرة

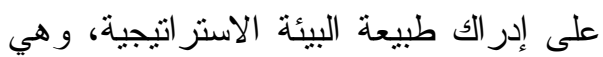

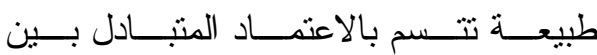
عناصــر ها، و متقلبـــة، ومعقدة،وغامــضـة الملامح. أمَّا التفكير الإبداعى: فهو القدرة على تطوير أفكار ومفاهيم جديدة تعرف القـضـايا

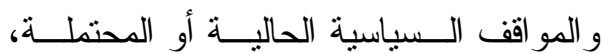
وتتشرحها، وتساعد علــى حلهــا، و التفكيــر

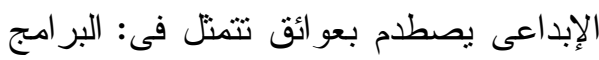

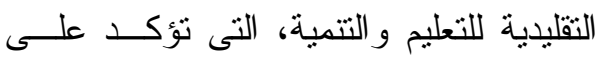

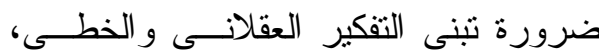
وتضع معايير محددة لطر ائق حل المشكلات

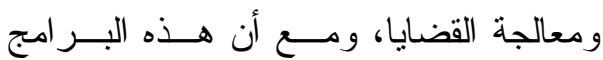

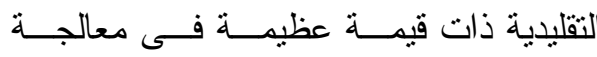


بدور دستورى، أو مكلفة بأدو ار ومهام فـى سياسة الدولة واستر اتيجيتها يحتاجون -أيضًا

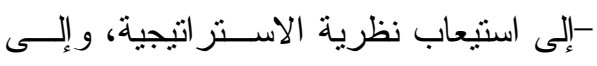

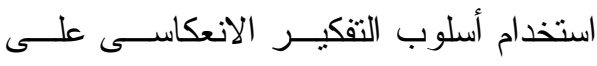

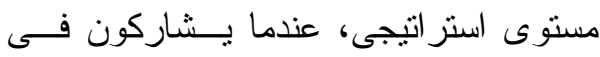
نقاثات فكرية.

وفى الحقيقة يمكن القول إن النظـــام

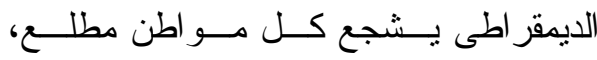

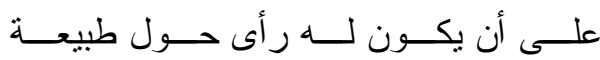

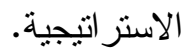

و هكذا نجد أن السياسة و الاسنز انيجية

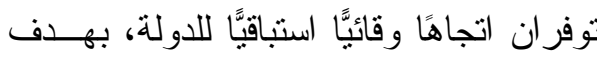

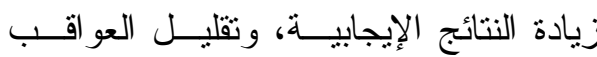

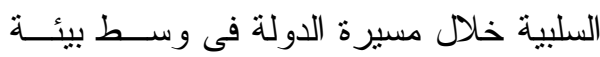
معقدة، ومتغيرة بسرعة نحو المستقبل. وذلك

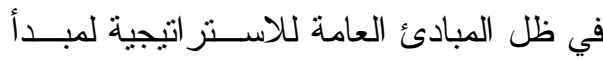

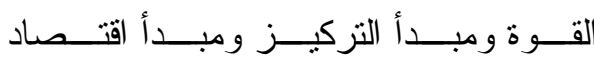

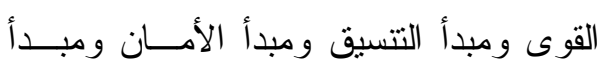

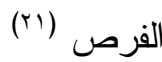

المبحث الثاني: استراتيجية الموارد البشرية والمنطق والبيئة الاستراتيجية البية

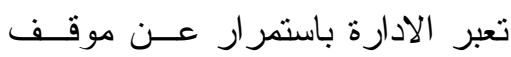

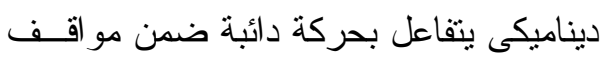

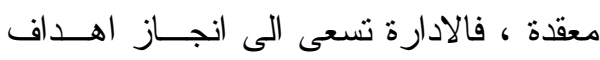

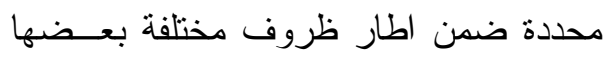

د.رضا خلاص، مروج الإدارة الاستر اتيجية،

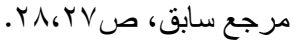

و هناك قاسم مشترك بين الأستاذ الملم بالأدو ار الثلاثة، و المتخصص فى كـلـل دور

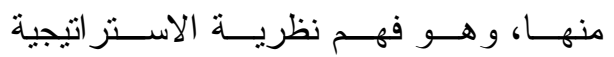

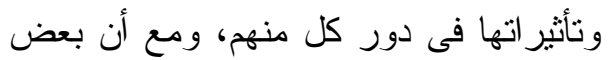
الأثخاص، الذين يؤدون هذه الأدوار، يمكن

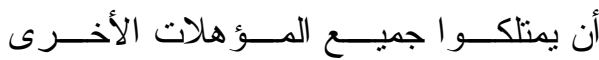

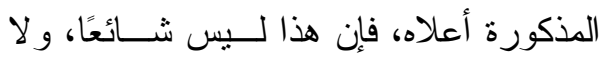

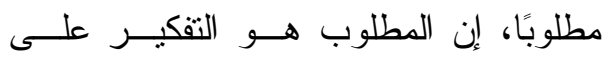
مستوى استر اتيجى، وتقهم النظريــــة و الآر اء المختلفة، وضم الأشخاص الذين يمتلكون هذه ونه القـــر ات إلـــى فريــق صـــــاغة الــسياسة و الاستر اتيجية.

ويعمل أعضاء فريق الأمن القــومى لئه

فى مستويات مختلفة، أو فى أدوار مختلفــــة الدئة

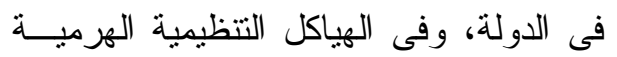

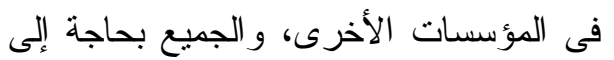

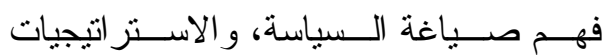

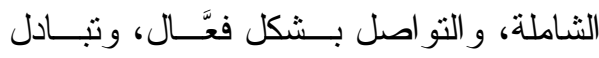
المعلومـــات فيمـــــــــــهم، وبــين القيــادة

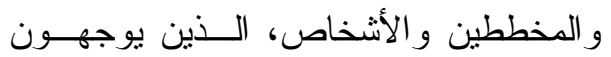
المؤسسات، التى تتفذ السياسة و الاستر اتيجية، ولانئ وبين الثعب فى نهاية المطاف.

وبدرجة مساوية يمكـن القــول إن أعضاء الفريق العاملين فى مجتمــع الأمــن القومى، و الموجودين فى السلطة التـشريعية

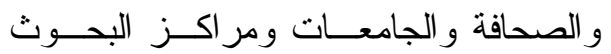

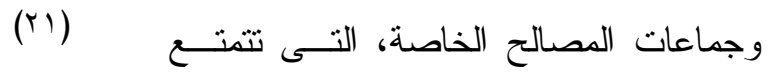


للحصول على نتائج مستقبلية أفضل حـالاً، مما يمكن أن تكون عليه لو نركت الأمسـور للمصادفة أو فى أيدي الآخرين.

كما يتضمن تحليل العلاقـــة بـين ائين

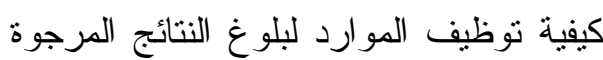

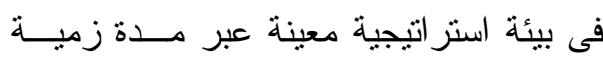

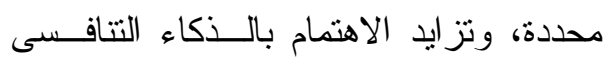

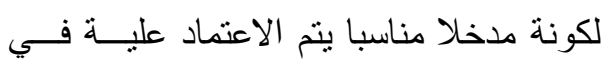

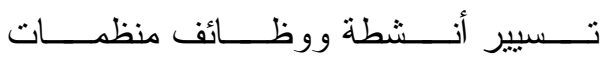
الاعمال. (r) (r)

وتــدور عمليــة التقكيــر و المنطــق

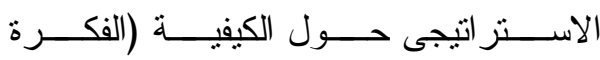

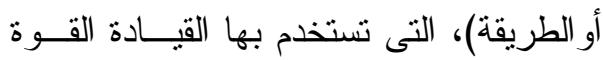

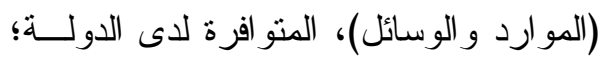

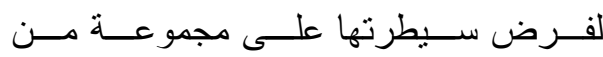

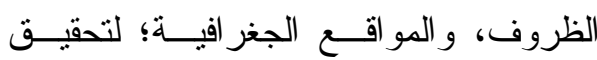
الأهداف (الغايات)، بما ينسجم وسياسة الدولة

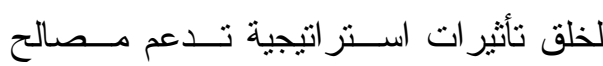
الدولة. و هكذا فإننا نستطيع تحديد عدة مقو لات

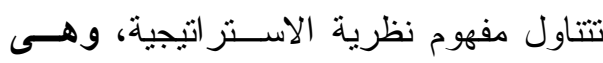
على النحو التالى:

د.معن وعد اللة المعاضيدى،د. وزيرة يحيى محمد سليمان، تاثير الذكاء التنافسى في تحديد

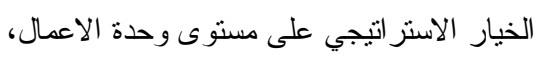

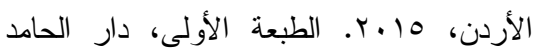

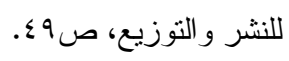

يساعد المنظمة على اغتتام الفرص و البعض الاخر يشكل قيودا ومخاطر عليها.

ومن هنا تاتى اهمية اختيــار البــــائل

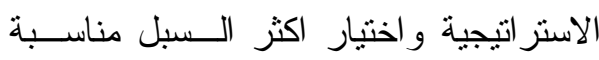

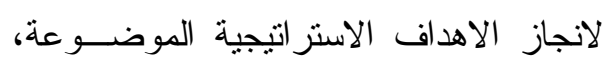
ويشتمل ذلك على دراسة متعمقـــة للبـــــائل

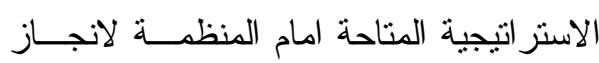
اهدافها على المستويات المختلفة.

ومن هنا تتبلور استر اتيجية المــوارد البشرية فى مدى العلاقة بين الموارد البشرية

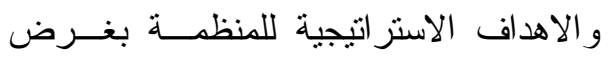
تحسين ادائها وتظوير ثقافة المنظمــة مــن

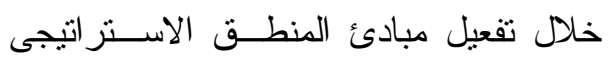
الرشيد من اجل زيادة مرونتها و ابداعها.

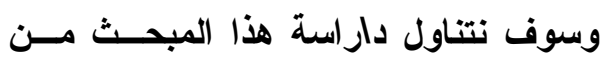

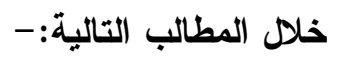
المطلب الاول: المنطق الاستر اتيجى. المطلب الثانى: البـــائل الاســنز انتيجية

$$
\text { و البيئة. }
$$

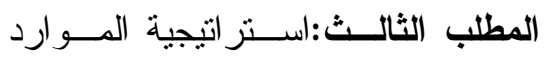

$$
\text { البشرية. }
$$

\section{المطلب الاول :المنطق الاستراتيجي}

تقدم الاستر اتيجية مخططًا لردم الفجوة

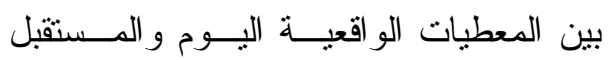
المنشود، ويتضمن هذا المشروع الحـسابات المنضبطة للأهداف الطموحسـة، و المفــاهيم و الموارد ضمن حـدود مقبولـــة للمخــاطر 
المقولة الخامسة: أن الاســتراتيجية

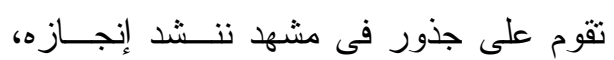

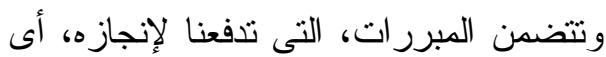

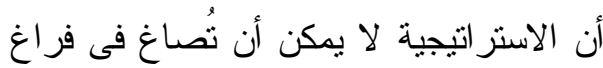

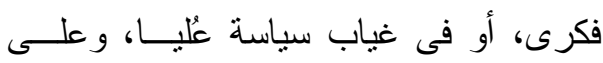

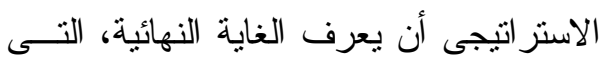

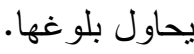

\section{المقولة السادسة: أن الاســر اتيجية}

مشروع إنسانى فى الأصل، و لا يقتصر على الى نلى

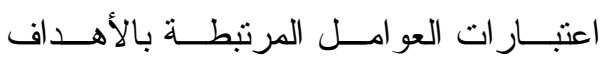
(فالاستر اتيجية تشمل العو اطــف الإنـسانية، و القيم و المعتقدات، وقلة من هذه الأشياء قابلة للقياس الكمى).

المقولة السابعة: أن الخلاف جـزء

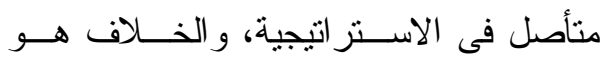

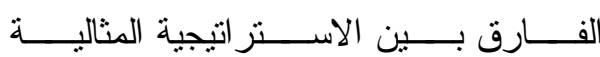
و الاستر اتيجية المطبقة، أى بين الكيفية التـى لـى التئه

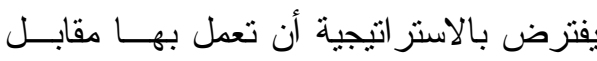

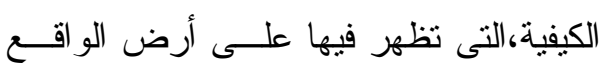

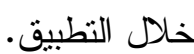

\section{المقولة الثامنــة: أن الاســتر اتيجية}

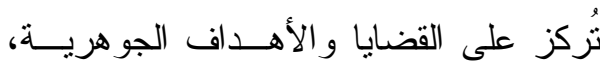

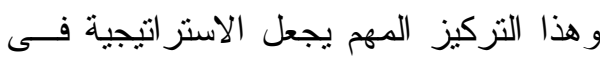

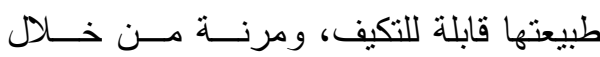

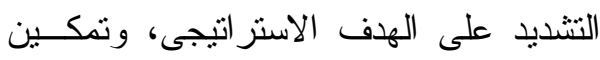

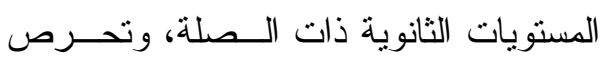

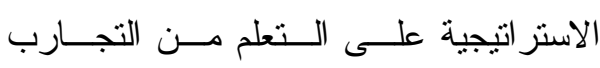

المقولة الأولى: أن الاستر اتيجية خطة

استباقية توقعية، ولكنها ليست تتبؤية.

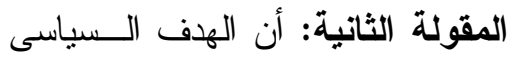

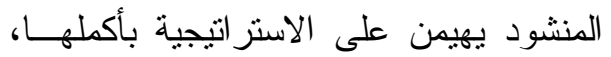

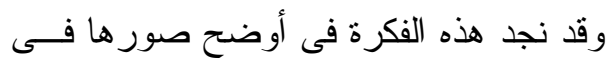

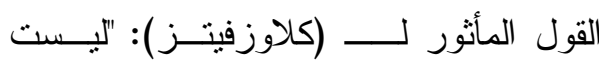
الحرب سوى مو اصــلة الــسياسة بوســائل

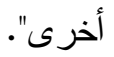

المقولــة الثالثــة: أن الاســـتر اتيجية

خاضعة لطبيعة البيئة الاستر اتيجية، ومنأثرة بظروفها المتداخلة، ويتم تطوير الاستر اتيجية بالتحليل الشامل للموقف الاستر اتيجي. المقولة الرابعــة: أن الاســنز اتيجية نظرة كلية شاملة، وهى تتطلب تحليلًا شاملاً،

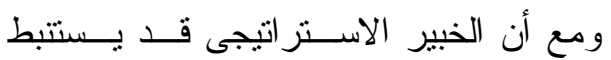

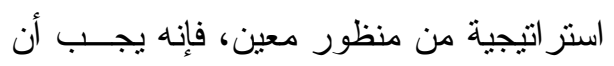
يأخذ فى الحسبان البيئة الاستر اتيجية بأكملها فى تحليلاته؛ ليتوصل إلى استر اتيجية مناسبة

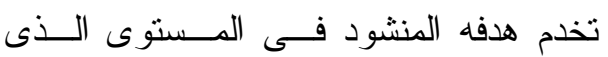

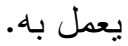
و هكذا فإن الاســتر اتيجي يجــب أن

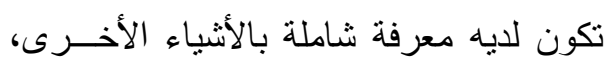

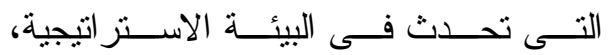

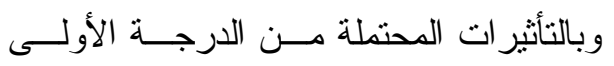
و الثانية و الثالثة .. إلخ، التى تحدثها خيار اتــهـ على جهود أولئك، الذين يعملون فوق ودون مستو اه، مستو اه، وفى مستو اه 
المقولة الثانية عـشرة: أن الكفــاءة

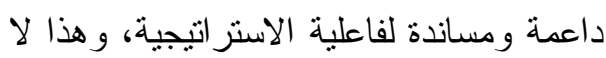

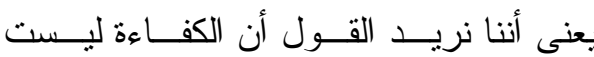
مطلوبة، فالاستر اتيجية الجيدة تكــون فعَّالـــة وعالية الكفاءة، والأهداف الاستر اتيجية عليها أن تتحقق تخلق - أو تُسهم فى خلق - نتائج

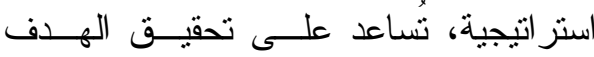
النهائى المنشود على مستوى الاســتر اتيجية التى يتم تحليلها.

\section{المقولــــــة الثالثـــــة عــــشرة: أن}

الاستر اتيجية تقدم علاقة صحيحة، أو تحقــق

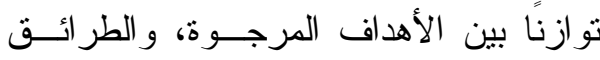

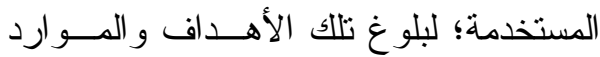

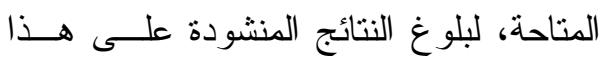
المستوى من التركيـــة الهرميــة، وخـــلال صياغة الاستر اتيجية، فإن الغايات و الوسائل

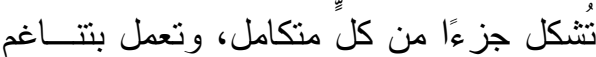
كامل لتحقيق النتيجة الاستر اتيجية المرجــوة على هذا المستوى من الاستر اتيجية.

\section{المطلب الثانى :البدائل الاستراتيجية والبيئة:}

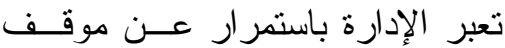

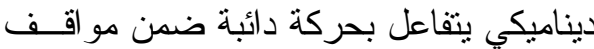

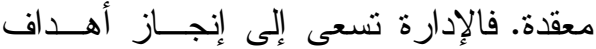
محددة ضمن إطار ظروف مختلفة بعـضها يُساعد المؤسسة ويدفعها إلى الأمام (فرص)، و البعض الآخر يكبح نشاطها، ويشكل قيـــــا

$$
\text { عليها (مخاطر). }
$$

السابقة، وهي ذات بنية و اســعة، بـصورة كافية، للتكيف مع ما يستجد من أحداث. المقولة التاســعة: أن الاســتراتيجية تخضع لتر اتبية هرمية، فالقيــادة الــسياسية

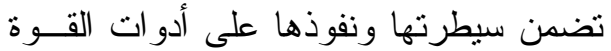

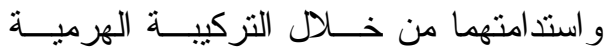
لاستر اتيجية الدولة، وتتدفق الاستر اتيجية من

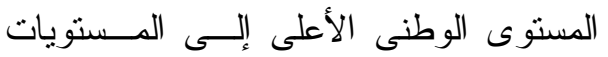

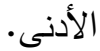

المقولة العاشـــرة: أن الاســتز اتيجية

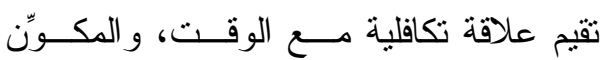
الرئيسى للكفاءة الاستر اتيجة، هو التفكير فى التى

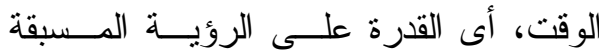
لاستمر ارية ارتباط الخيارات الاسـتـراتيجية

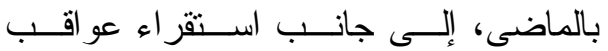

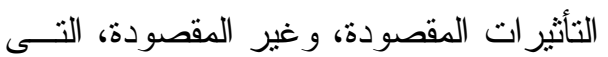
تخلقها تلك الخيار ات فى المستقبل.

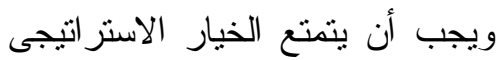

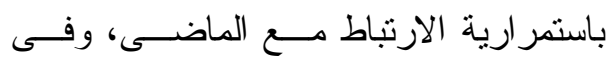

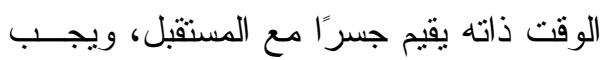

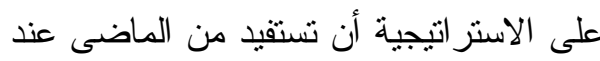

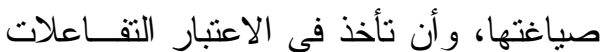

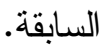

المقولــــة الحاديــــة عــــرة: أن

الاستر اتيجية عملية تر اكمية، و النتــائج فـى لـ لـ

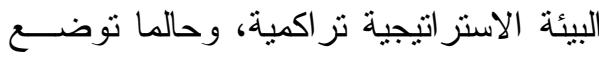

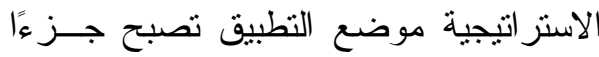
من لعبة الاستمر ارية، و التغيير . 


$$
\begin{aligned}
& \text { المؤسسة، إذا كان الجـــواب بـــــ (لا)، } \\
& \text { إن القاعدة الأساسية في هذا الــسياق }
\end{aligned}
$$

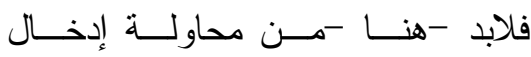

$$
\begin{aligned}
& \text { التعديلات المطلوبة. } \\
& \text { r. هل هذا البديل الاستر اتيجي متتاسب مع }
\end{aligned}
$$

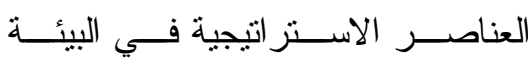

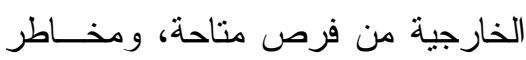

$$
\begin{aligned}
& \text { تو اجهها! } \\
& \text { ז. هل يتطابق هذا البديل مــع العناصــر }
\end{aligned}
$$

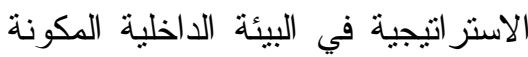

$$
\begin{aligned}
& \text { من نقاط القوة، ونقاط الضعف في البناء }
\end{aligned}
$$

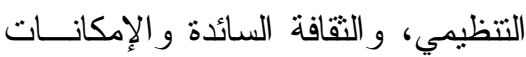

$$
\begin{aligned}
& \text { المُتاحة في المؤسسة؟ وكي } \\
& \text { ـ. هل يعكس هذا البــديل الحــد الأدنــى } \\
& \text { المقبول من المخاطرة عند تطبيقه. } \\
& \text { هـ هل هذا البديل قابل لأن يساعد المؤسسة } \\
& \text { على احتلال جانب محدد غير مـستغل } \\
& \text { من سوق المؤسسة الحالي؟ } \\
& \text { 7. هل يتصادم هذا البديل الاستراتيجي مع لع } \\
& \text { أيٍٍ من الاستر اتيجيات الأخرى المطبقة }
\end{aligned}
$$

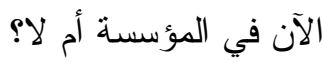

$$
\begin{aligned}
& \text { V. هل أجزاء هـــاء البــديل الاســتراتيجي التهي }
\end{aligned}
$$

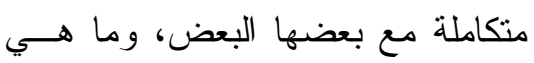

$$
\begin{aligned}
& \text { درجة التكامل بينها؟ } \\
& \text { ^. هل تم اختبار هذا البديل الاســتراتيجي }
\end{aligned}
$$

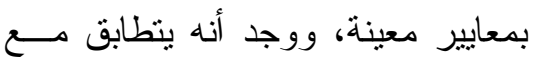

$$
\begin{aligned}
& \text { تجربة المؤسسة في الماضي في المجال } \\
& \text { الاستر اتيجي، ومصع التجربـــة الحاليــة، }
\end{aligned}
$$

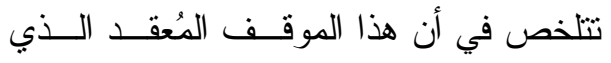

$$
\begin{aligned}
& \text { تكتنفه درجة عالية من عدم التأكد يتطلب من } \\
& \text { المؤسسة قدرات خاصة ثنائية الاتجاه، فمـن تصن } \\
& \text { جهة، عليها أن تستغل الفرص المتاحة بأعلى }
\end{aligned}
$$

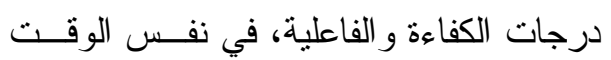

$$
\begin{aligned}
& \text { الذي تسعى فيه وبقوة إلى تجنب المخــاطر }
\end{aligned}
$$

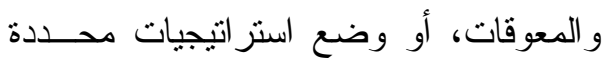

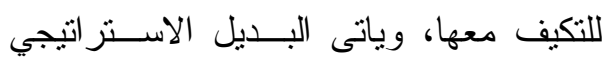

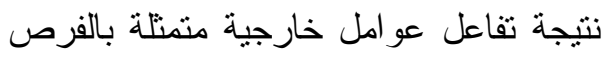

$$
\begin{aligned}
& \text { و التهديدات من ناحية، ومجموعة من العو امل بل بله }
\end{aligned}
$$

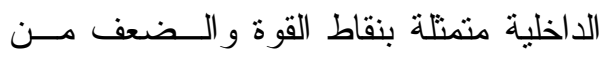

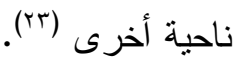

$$
\begin{aligned}
& \text { اختيار البديل الاستراتيجي المناسب: } \\
& \text { وفي التطبيق فان عملية اختيار بــديل } \\
& \text { بعينه من بين كل البدائل المُتاحة عملية ليست }
\end{aligned}
$$

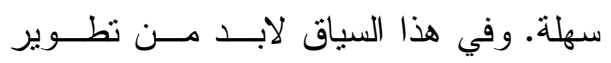

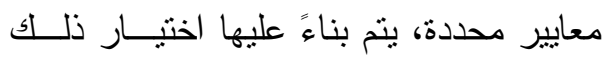

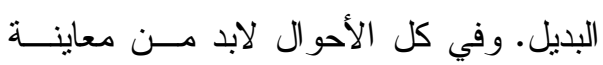

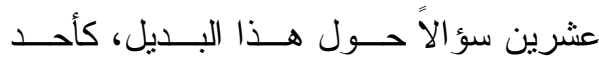

$$
\begin{aligned}
& \text { الأساليب المُساعدة في عملية اختباره، وهـي لــي } \\
& \text { كما يلي: } \\
& \text { ا ـ هل يتطابق هـــا البـديل مــع رســالة } \\
& \text { د.ثائر شاكر محمود الهيتى، د. سامى ذياب }
\end{aligned}
$$


11. هل تمت عمليـة دراســة الوضــع

التتافسي للسوق قبل اختيار هذا البديل

ووضعه موضع التنفيذ أم لا؟

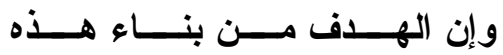

الاستر اتيجيات المحددة موجه إلــى إنجــاز

النتائج الثلاثة التالية:

تعظيم قدرة المؤسسة على اســـتخدام

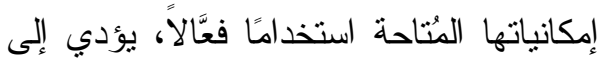

$$
\text { تحقيق الأهداف الموضوعة. }
$$

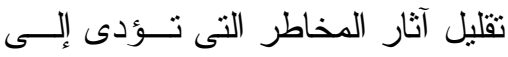

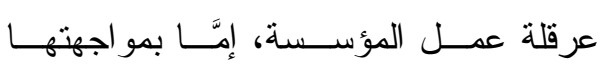

و إز التها، أو بتحييد تأثثير اتها على استر اتيجية

$$
\text { المؤسسة. }
$$

تعزيز القــدرة الفعَّاَـــة علــى إدارة

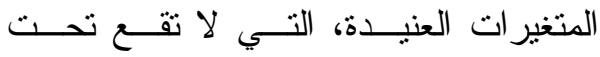

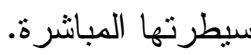

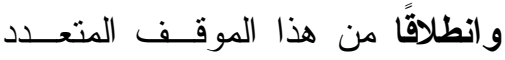

الأبعاد، فإن المؤسسة تتبنى واحدة أو أكثــر

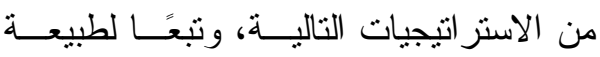

الموقف، ونوعية الاستجابة المرغوبة، وذلك

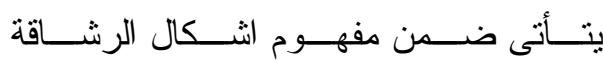

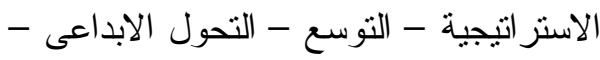

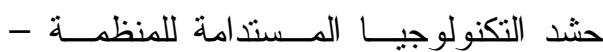

التحسين الجزرى (ء).

(ع ؟) د.يوسف عطيوى الو اضية، التعلم الاستراتيجي

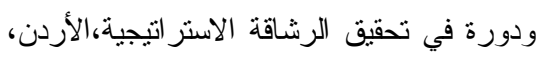

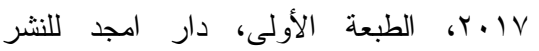

و التوزيع، صع 0.
وتللك المتوقعة في المستقبل؟ وهل تـــ إخضاعه لاختبار ات المخاطرة.إخج

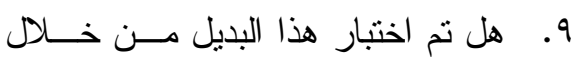

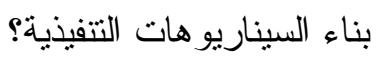

• 1 ـ هل يتتاسب هذا البديل الاســز اتيجي

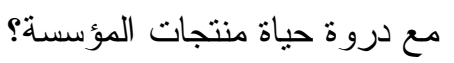

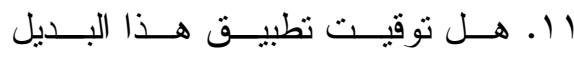

$$
\text { الاستز اتيجي مناسب؟ }
$$

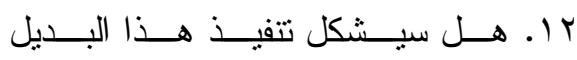

الاســـز اتيجي إضـــافة نوعيــة لأداء

المؤسسة النتافسي في أسواق منتجاتها

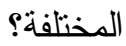

با ـ هـــل ســـؤدي تتفيــذ هــذا البــديل

الاستر اتيجي إلـى جعـلـ المؤسـسـة

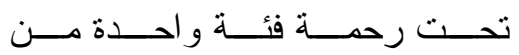

المستهلكين؟

ع ا ـ هل يتضمن هذا البديل الاســتراتيجي

إنتاج منتجات جديدة ليتم تسويقها فــي لي لئي

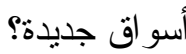

10. هل هذا البديل الاستراتيجي يتـضنمن

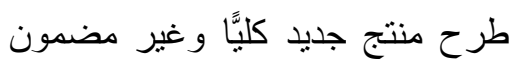

من الناحية النسويقية؟

17 ـ هل هذا البديل يعتبر تقليدًا لبديل لدى

إحدى المؤسسات المُنافسة؟ لهابِ

V ا. هل هذا البديل يمكِّ المؤسـسـة مــن

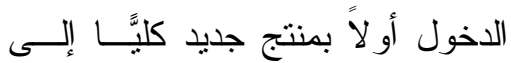

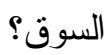


التوازن الديناميكي ما يلي:

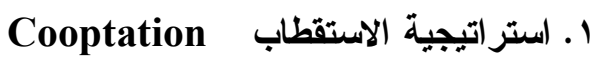

:( Strategy)

تتضمن هذه الاســتر اتيجية أن تقـوم

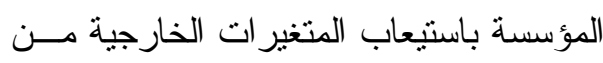

خلال إيجاد قو اسم مشتركة، وخلــق منـــافع

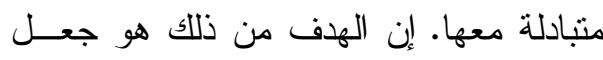

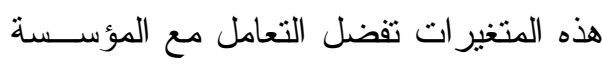

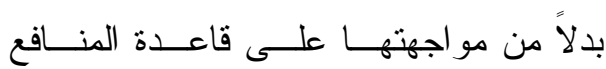

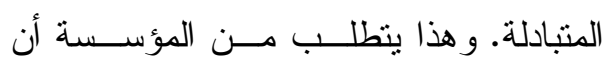

تحاول خلق موقف جذاب يجعل من مصلحة

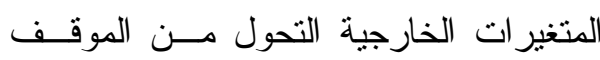

المضاد إلى الموقف المتعاون معها.

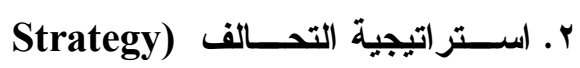

Coalition):

ترتكز هذه الاستر اتيجية على محاولـــة

المؤسسة إحداث ظروف تؤدي إلى خلق هُه

جبهة مشتركة مع بعـض المتنغيــرات

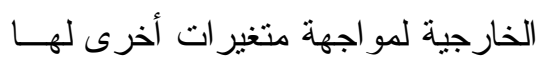

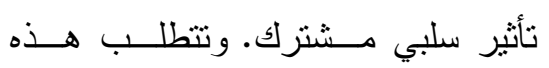

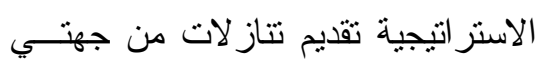

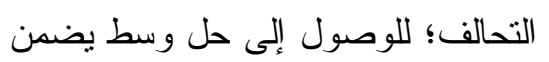

$$
\text { حقوق الأطر اف المتحالفة. }
$$

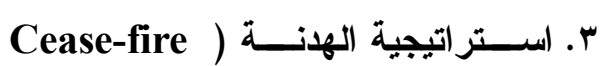

:(Strategy

تتضمن اســتر اتيجية الهدنــة أن تقـوم

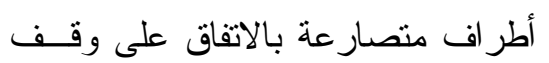

ومن الصور المتعددة لهذة البدائل ما يلى:

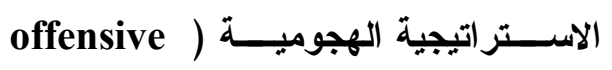

:(Strategy

تتطلق هذه الاستر اتيجية مــن مبـــــأ

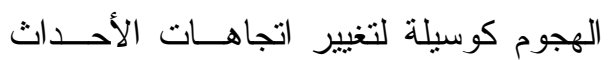
لصالح أهداف المؤسسة.

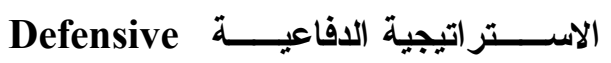

Strategy):

تتحو هذه الاستر اتيجية منحى مختلفً

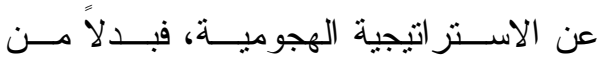

المواجهة تتحصن المؤسسة خلف إمكانياتها،

وذللك لحمايتها من هجوم من قبل الآخرين

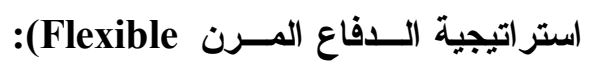

Defense Strategy)

تعتمد هذه الاستر اتيجية على أسـلوب

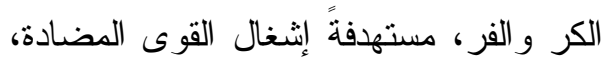
و إرباكها بطريقة تـسمح للمؤسـسـة بإعــادة

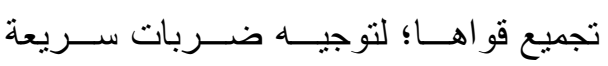

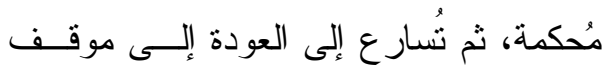

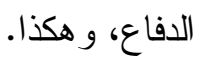
أثنكال العمل الاستر اتيجي:

نتيجة لطبيعة العلاقة المعقـدة بــين

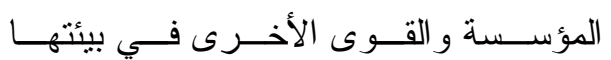

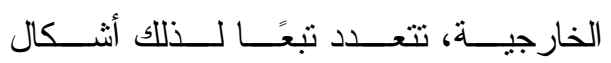
الاستر اتيجيات المُستخدمة لإحــــاث و إدامـــة

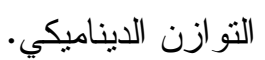

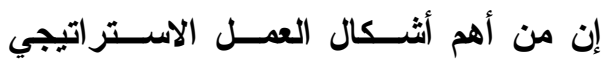

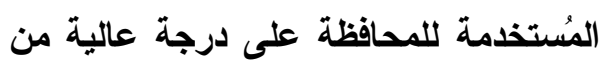




$$
\begin{aligned}
& \text { وهو كيفية در اسة وتحليـلـل واختيــار } \\
& \text { البدائل الاستر اتيجية. }
\end{aligned}
$$

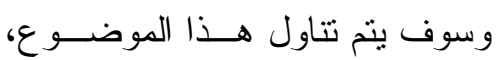

$$
\begin{aligned}
& \text { وذللك بتحديد البدائل الاستر اتيجية المناســبة }
\end{aligned}
$$

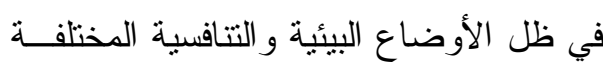

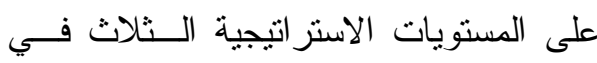

$$
\begin{aligned}
& \text { المؤسسة، وسيتم استكمال الحديث عن هــــه } \\
& \text { المستويات من حيث علاقتها باختيار البـــــئل ونئل } \\
& \text { الاستر اتيجية، كما هو موضح، فيما يلي: }
\end{aligned}
$$

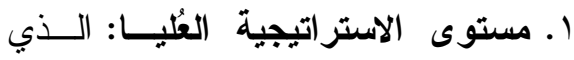

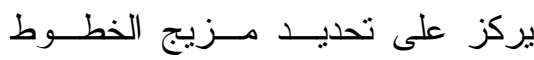

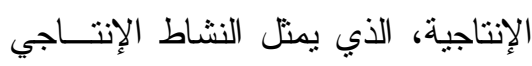

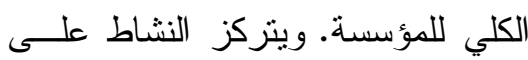

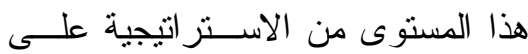

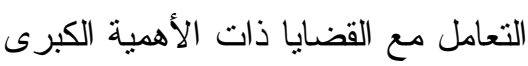

$$
\begin{aligned}
& \text { كتقديم إجابات على نساؤلات، من نوع: }
\end{aligned}
$$

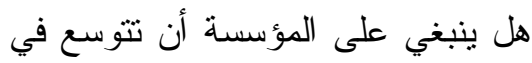

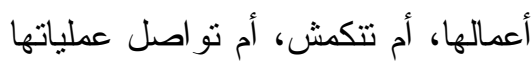

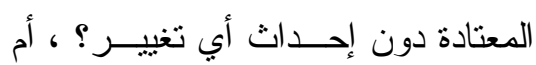

\begin{tabular}{|c|c|c|}
\hline \multirow{3}{*}{ العلمية للنشر } & & (ro) ا.د.سعد على العنزى، د.جو اد محسن راضى، \\
\hline & الطبعة الاوللى، دار اليازورى & التحالفات الاستر اتيجية في منظمات الاعمال \\
\hline & و التوزيع، صع^. & 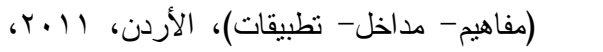 \\
\hline
\end{tabular}

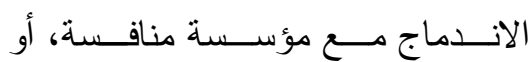

$$
\begin{aligned}
& \text { بو اسطة الثر اكة مع مؤسسات أخرى؟ } \\
& \text { r. مستوى الاستراتيجية الوظائفية: الذي مؤيسات لتركي } \\
& \text { يحدد الطرق التي ستمارس من خلالهـ التيـا }
\end{aligned}
$$

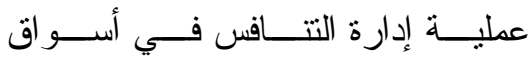

الصر اع، وتأجيله إلى مرحلـــة قادمــة.

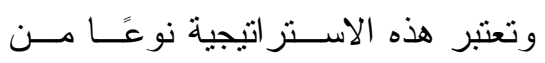

التفاوض المتفق عليه، بحيث يتم تأجيل

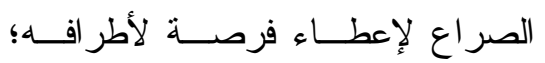

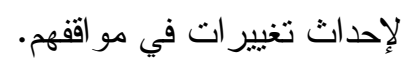

ـ ـ اســـتر اتيجية الآـــسحاب (Strategy)

\section{:(Withdrawal}

تتضمن استر اتيجية الانسحاب أن تقــوم

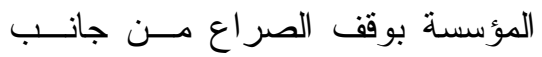

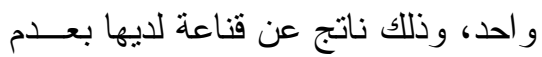

$$
\text { جدوى الاستمر ار فيه. }
$$

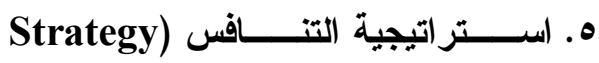

\section{:(Competitive}

تزتكز هذه الاستر اتيجية الأكثر شيوعًا

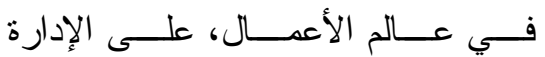

الاستر اتيجية للمؤسسة، وذللك باستخدام

أكثر الوسائل كفاءة وفاعلية في عمليــة

$$
\text { التتافس مع المتغير ات المضادة. }
$$

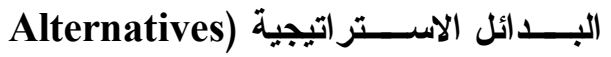

:(Strategic

ان المنظمة هي مجموعة من القــدرات

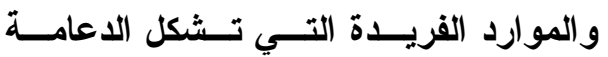

الأساسية لاستر اتيجيتها (ro).

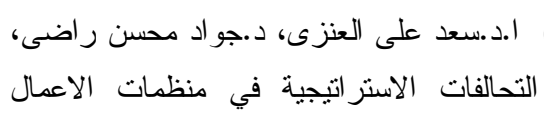

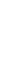


Stability ) اســـتراتيجيات الاســـتقرار

:(Strategy

ترتكز هذه الاستر اتيجية على فلـسفة

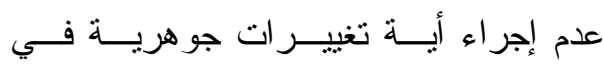

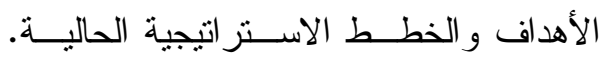

وتتاسب هذه الاستر اتيجية مؤسسة ناجحة في

أعمالها تعمل في بيئة تتافسية مستقرة، وبيئة خارجية راكدة تقل فيهــا أســباب التغييــر

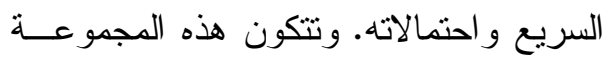
من البدائل الاستر اتيجية التالية:

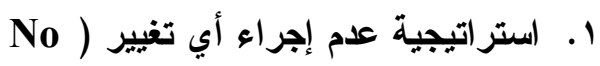

\section{:(Change Strategy}

تتطلب هذه الاستر اتيجية الإبقاء على

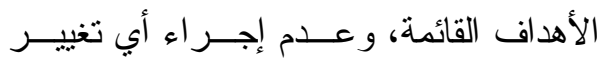

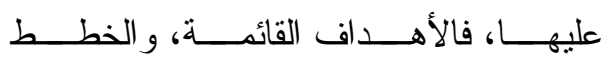

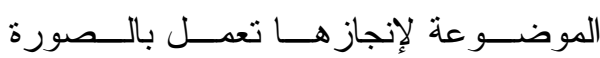

المطلوبة، وليس هنالك أي مبرر لتغييرهــا.

ويعتمد نجاح هذه الاستر اتيجية على انعــدام

التغيير في بيئتي المؤسسة، التي تتنبى هــــه

$$
\text { الاستر اتيجية. }
$$

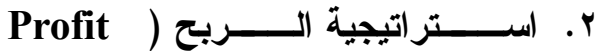

:(Strategy

تعتمد هذه الاستر اتيجية على تخفيض

كبير في حجم الموارد المخصصة للإنفــاق

على المصاريف الحرجة، التى تعرف بأنهــا

تلك المصاريف التي تتفـق الآن، وتظهـر

$$
\text { آثار ها الإيجابية في المستقبل. }
$$

المؤسسة المختلفـــة. و إدارة العمليــات التتافسية تتم بطرق مختلفة، فبعضها يتم على أساس التتافس باعتماد استراتيجية الكلفة المُنخفضة، بينما بعضها الآخــر

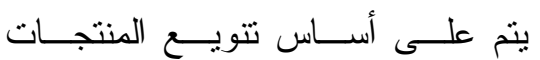

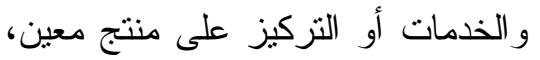
و إنتاجه بنو عية عالية جدًا.

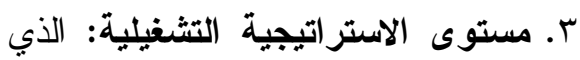

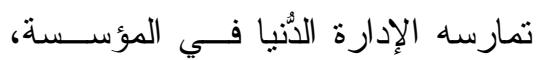
الذي يحدد كيفية توفير الــستّبل الكفيلــة بتعظيم إنتاجية الموارد المُتاحسـة فـــي لوني

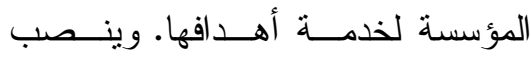
التزكيز في هذا المستوى علــى إيجـاد الطرق الكفيلة، التي تـساعد الـــدوائر

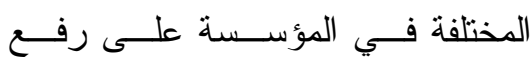
إنتاجيتها فـي الاســتر اتيجية الـشاملة

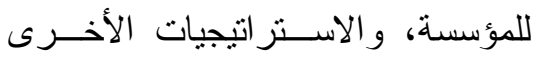
على مستوى الإدارة الوسطى.

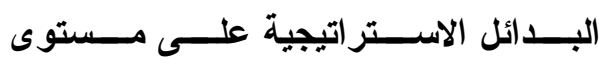
الاستر اتيجية العُليا: وفى ظل تعريف الميزة النتافسية بانها قدرة المنظمة على تحقيق التفوق و الافــلية

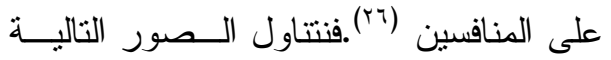

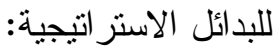

(דr)|.د.سعد على العنزى،د.جو اد محسن راضى،

التحالفات الاستراتيجية في منظمات الاعمال (مفاهيم-مداخل-تطبيقات )، مرجع سابق، . ص 
(أ) أستراتيجية النمو الأققي Growth)

\section{:(Horizontal}

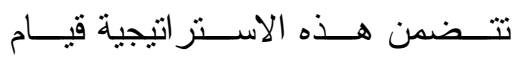

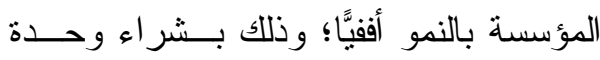

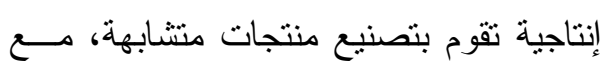

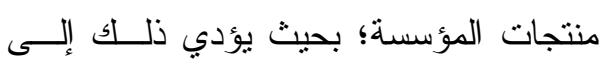

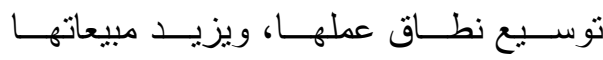

وأرباحها، ويغطي أسو اقًا جغر افية جديدة.

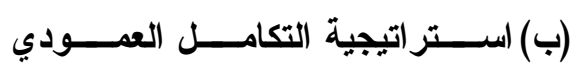

:(Vertical Integration)

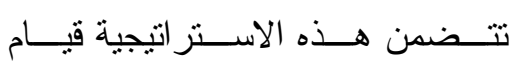

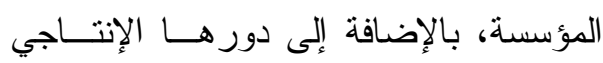

بالسيطرة على مصادر التزويد، أو السيطرة

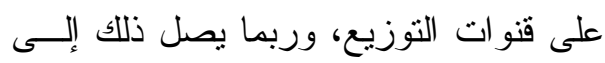

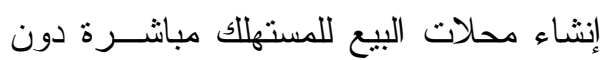

وسيط.

1. استر اتيجية التوســع إلــى صـــاعات

$$
\text { مختلفة }
$$

(Diversification Strateg):

تعرف استر اتيجية التوسع بأنها عملية

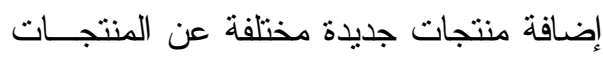

الحالية إلى المزيج الإنتاجي في المؤسسة.

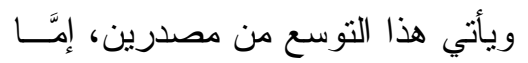

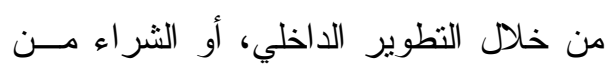

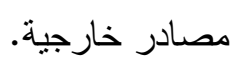

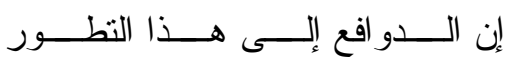

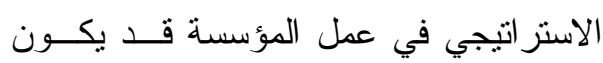

r. استراتيجية التقدم الحذر إلى الأمام Proceed-with-Caution Strategy

تزتكز هذه الاستر اتيجية على فلـسفة

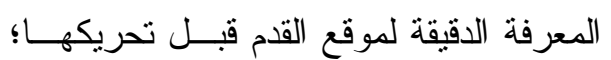

تجنبًا للمفاجآت. وتتطلب -عــادة -مر اقبـــة

و اعية متأنية لعو امل استراتيجية غير محددة الاتجاه في البيئة الخارجية.

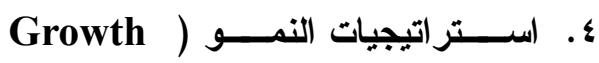

:(Strategy

في هذه المجموعة من الاستر اتيجيات

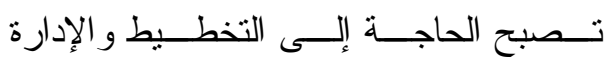

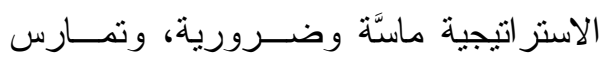
على أوسع نطاق ممكن. وتعتبر استز اتيجيات

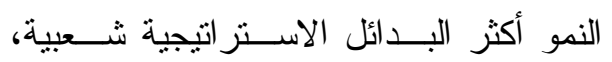
وبالتالي استخدامًا؛ لكون النمو يرتبط -دائمًا -مع النجاح و السمعة الطيبة. حيث بــصبح برنيط النمو بمثابة قارب الأمان، و الوسيلة الفعَّاســة ولـة

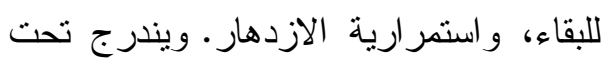
هذه المجموعة من الاســنز اتيجيات بــديلان استر اتيجيان، هما: ه. استراتيجية التركيز في صناعة واحدة :(Concentration Strategy)

تتضمن هذه الاســترانيجية التركيـز

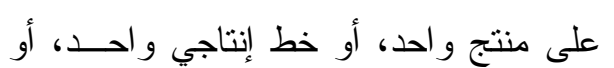

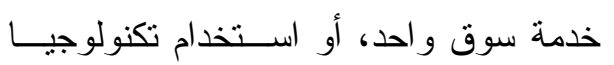

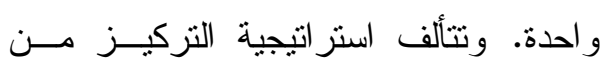
بديلين اثثين، هما: 
r. مدى التحسن المتوقــع فــي وضـــع

المؤسسة بعد التوسع: إن المنتجــات

التى سنتجها المؤسسة في الصناعات،

التي تتوسع إليها يجب ألا نؤدي إلـى لـى

إضعاف منتجاتها الحالية.

ويمجرد أن يتخذ قرار التوسع، يتم اتبــاع

واحد أو أكثر من الطرق التالية لإتمامه:

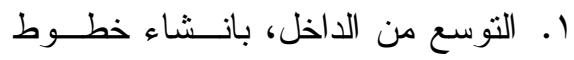

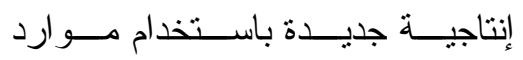

المؤسسة المالية المُتاحة.

r. التوسع باستخدام المصادر الخارجية،

أو ما يُسمى بالتحالفات الاســتر اتيجية

وذلـــــــ (Strategic Alliances)

باختيار الاندماج مع مؤسسة أخــرى، ودل،

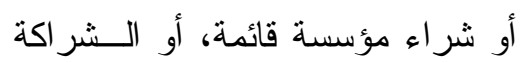

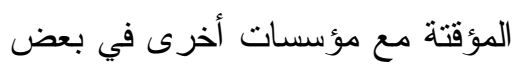

الجو انب الإنتاجية المناسبة.

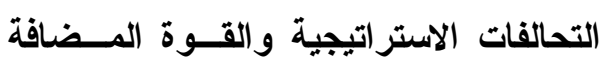

Strategic Alliances and Synergy)

تهدف التحالفات الاستر اتيجية بكافــة

أنو اعها إلى تجميــع إمكانيــات المؤســسات

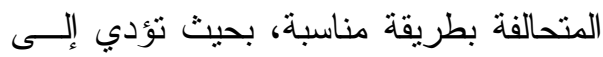

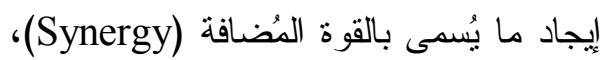

وهي القوة الناتجة عن التكامل الاســتر اتيجي

المُناسب بين المؤسسات المتحالفة، بالإضافة

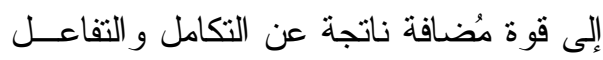

بينها متحدة. وهنالك اهتمام خاص قد تركــز
و احدًا أو أكثر من الدوافع التالية:

> الرغبة في تقليص اعتماد المؤسسة على الى لهن

صناعة و احدة؛ تحسبًا من تدني مستوى

جاذبية منتجاتها في المستقبل.

> الرغبة في التغلب على مجموعــة مـنـ

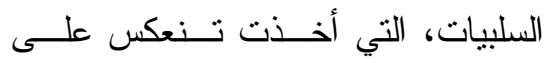

مستوى ربحية المؤسسة، وذلك بالدخول

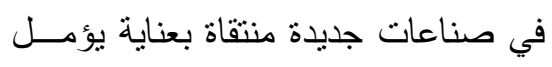

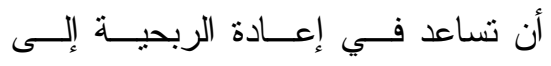

$$
\text { المستويات المقبولة. }
$$

الرغبة في عدم وضع جميع ما لــدى

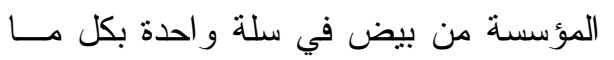
يحمله ذلك من احتمالات.

و هذه الدر سات تـت قبل اتخاذ القــرار

حول طبيعة العمل، الذي تتــوي المؤسـسـة

التوسع فيه، وتتضمن هذه الدراسات ما يلي:

ا. مدى جاذبية التوسع: إن العمل الـذئي

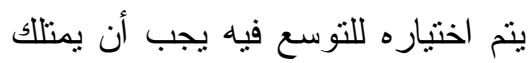

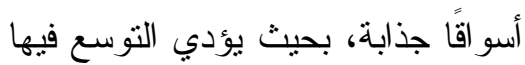

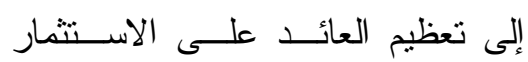
مسنقبلا.

r. كلفة الاخول إلى الصناعة المستهدفة: يجب ألا تكون الكلفة المتوقعة للتوسع

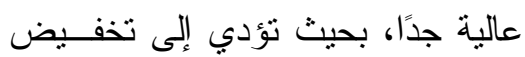

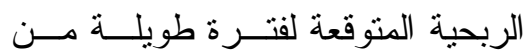
الزمن. 


$$
\text { المُضافة (Synergy) بينها. }
$$

وينظر إلى هذا التحالف على أنه خبار

استر اتيجي مهم؛ بسبب مجموعة من المزايا التي يمتلكها كالتالى:

ا ـ تعتبر الثر اكة المؤقتة وســيلة مهمـــة

لتشجيع القرارات الإدارية الجزئية التي لتئي

تتصف بالمغامرة إلى حد ما، وذلك لأن

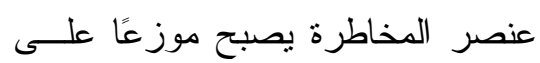
أكثر من مؤسسة واحدة.

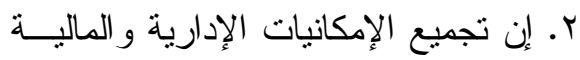

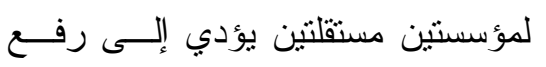

أدائهما التنافسي إلى مستويات أعلى.

r. يُعتبر هذا التحالف استر اتيجية فعَّلة إذا لئي

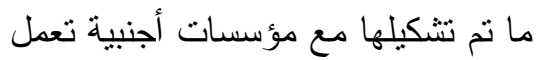

$$
\text { في أسو اقها الوطنية. }
$$

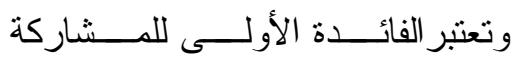

التعاونية و اسعة النطاق وهى انها عادة مــــا

تولد أفكار ا اكثر و أفضل (r^).

أنواع استر اتيجية التوسع:

تتضمن استر اتيجية التوسع، أن تقــوم

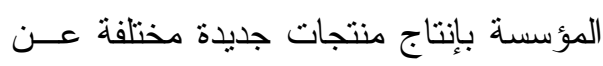

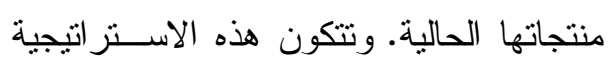

من بديلين استر اتيجيين، هما:

ما (YN)

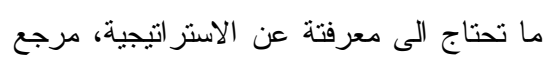

في الآونة الأخيرة بشان نلك القدرات التـي

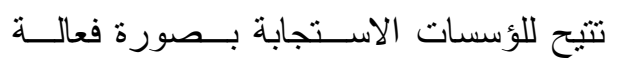

للتغير ات العنيفة، (TV) وتعتبر القوة المُضافة

الدافع الرئيسي للتحالفات الاستر اتيجية. وفيما

يلي وصف لهذه التحالفات الاستر اتيجية:

الاندماج (Merger):

يتم تتفيذ هذه الاســتر اتيجية بانــدماج

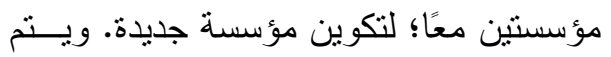

عادة الاندماج بين مؤسستين متقاربتين فـي مئي

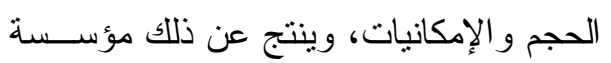

جديدة.

(Acquisition): الاستحو اذيدة

يتضمن شراء مؤسسة قائمة أصــغر

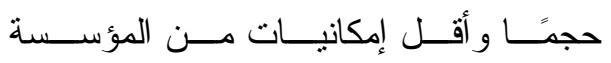

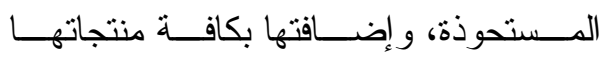

وخطوطها الإنتاجية إليها.

الثر اكة المؤقتة (Joint Venture):

يتضمن هذا النــوع مــن التحالفـــات

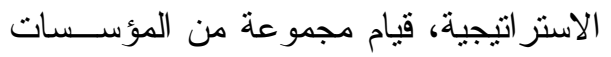

بالاتفاق على شر اكه فيمـــا بينهـــا؛ لإنجـــاز

مشروع مشترك يتوقع أن يؤدي إلى تحسين

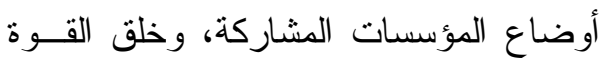

(YV)

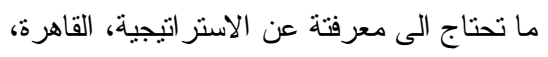

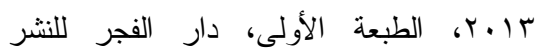

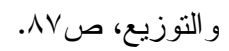


منتجات أو خطوط إنتاجية جديدة كليَّـا إلـى

عمل المؤسسة، و لا ترتبط بالمنتجات القائمة بأية رابطة.

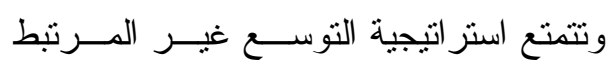
بمجموعة من المزايا، وعلى الوجه التالي: ا. تؤدي إلى توزيع المخاطر على أكتهـر

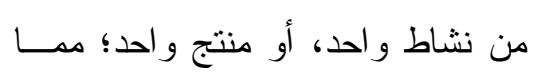

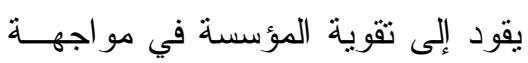

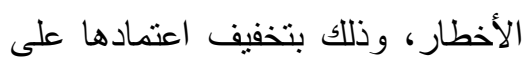

$$
\text { صناعة و احدة. }
$$

r. يجعل من الممكن اســثتمار المــوارد

الر أسمالية المتاحة في المؤسسة في أي

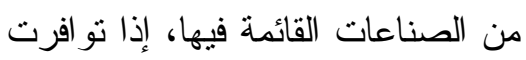

الثروط الاستثمارية المناسبة.

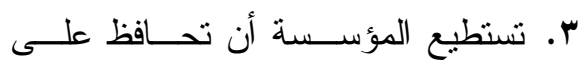

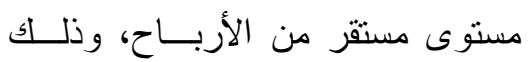

بالتعويض بين المنتجات التي تدر ربحًا

عاليًا، وتلك التي تُعاني من مشاكل في بين

$$
\text { ربحيتها. }
$$

$$
\text { r. - استراتيجية الاكماش ربنا. }
$$

\section{(Retrenchment Strategy):}

يُشكل الفنشل الدافع الرئيسي لاستخدام

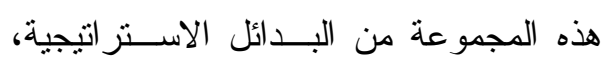
وتعتبر أقل البدائل الاستر اتيجية شعبية، لكنها

بد ائل مهمة ضمن ظروفها. وتتكون من ثناثة

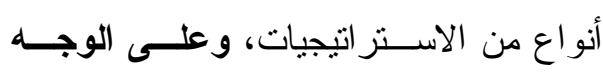

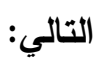

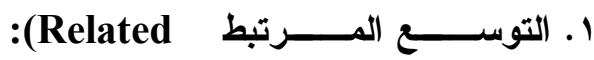

Diversification)

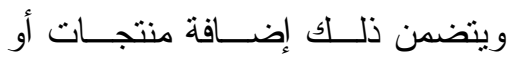

خطوط إنتاجية جديدة مرتبطة مع منتجــات

المؤسسة القائمة.

إن من الإرشادات، التي لابد أن تؤخذ

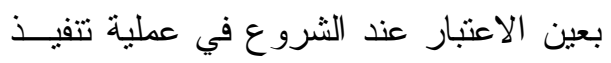
استر اتيجية التوسع المرتبط ما يلي:

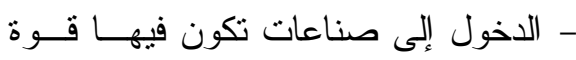

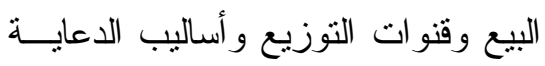

والإعلان لترويج المنتجات مشتركة بين

$$
\text { المنتجات الجديدة و الحالية. }
$$

- الدخول إلى صناعات تتطلب اســتخدام

نفس التكنولوجيا التي تستخدم في إنتـاج

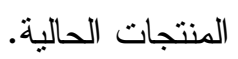

- الدخول إلى صناعات يتم بسهولة نقــلــل

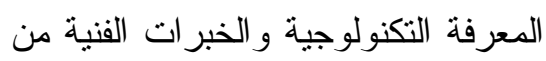

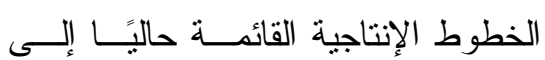

الخطوط الإنتاجية الجديدة.

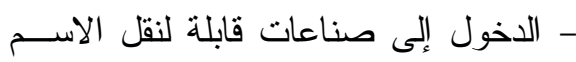

التجاري و السمعة المميزة من المنتجات

الحالية إلى المنتجات الجديدة أو العكس.

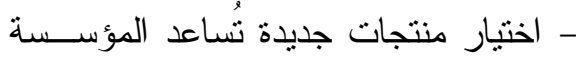

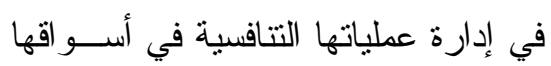

القائمة أو المتوقعة بصورة أكثر فاعلية.

r. التوسع غير المـرتبط Unrelated):

Diversification)

يتضمن هذا النوع من التوسع إضافة 
تتاسب مؤسسة تُعاني من شحِّ في المــوارد

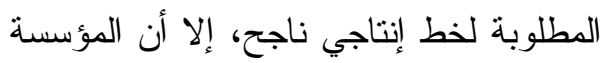

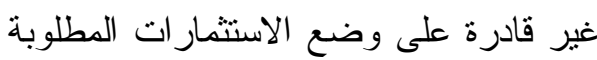

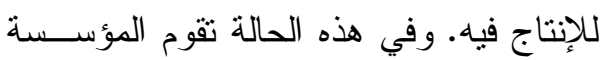
ببيع بعض فروعها، أو خطوطها الإنتاجيـــة؛

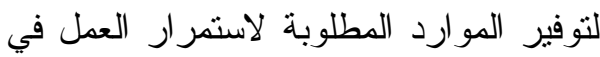
ذللك الخط الإنتاجي.

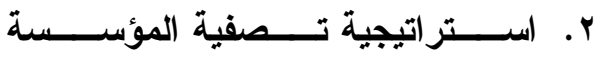
:(Liquidation Strategy)

عندما تفنل الاستراتيجيات المذكورة

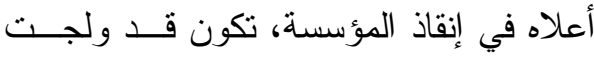
باب النصفية النهائية. وبانتهاء ذلك تكون المؤسسة قد فقدت شخصيتها الاعتبارية القانونية، و اختفت مــن لـن

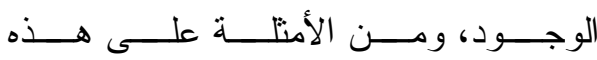

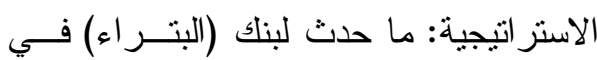
الأردن، و (بنك التجارة و الاعتماد الدولي) في لاليتري الإمارات العربية المتحدة، كمــا ان هنــاك اهتمام خاص قد تزكز في الآونــة الأخيــرة

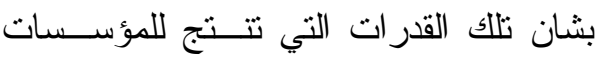

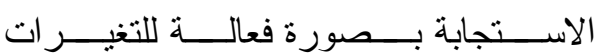
العنيفة. (rq)

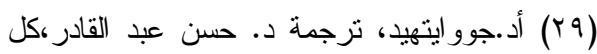
ما تحتاج الى معرفتة عن الاستر اتيجية، مرجع

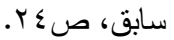

ـ ـ استر اتيجية الإنقــاذ Turnaround)

:Strategy)

تهدف هذه الاستر اتيجية إلى محاولــة تحسين كفاءة العمليات في المؤسسة، وتتاسب

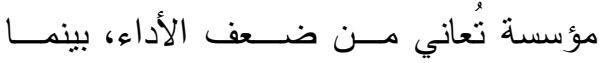

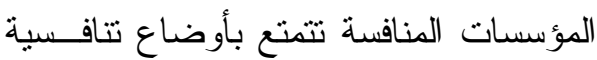
قوية، وتتم هذه الاستر اتيجية من خلال ثنات بات بات مر احل، وذلك على النحو التالى:

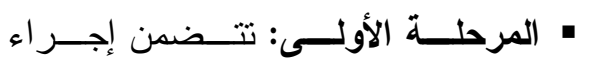
تخفيضات ملموسة في كلفــة العمليــات وحجمها. ويتطلب ذلك إجر اء تخفيضات في لكهي مهمة في الموارد المرصودة للنـشاطات غير الحرجة في المؤسسة. • المرحلة الثانية: نتشل إجر اءات مناسبة؛ لتنبيت عملية الاستقرار التي تحققت في التئل المرحلة الأولى. • المرحلة الثالثة: وهي مرحلــة إعــادة

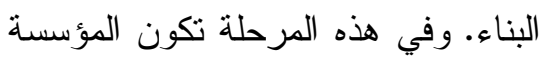
قد تجاوزت مرحلة الأزمة، و عادت إلى لى لـاهل ممارسة عملها بالطريقة المُعتادة.

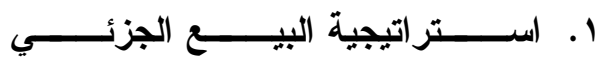

:(Divesture Strategy)

تتاسب هذه الاســتر اتيجية مؤسـسة وجدت أن سبب المشاكل التي تعانيها عائــــ

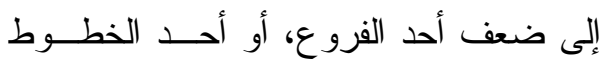

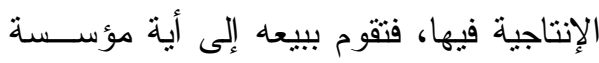

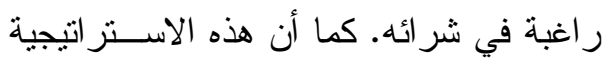


r. Focus ） (ســـتراتيجية التركيــز

:Strategy

تتضمن هذه الاستر اتيجية قيام وحدة

العمل الاستر اتيجية في المؤسـسة بــالتركيز

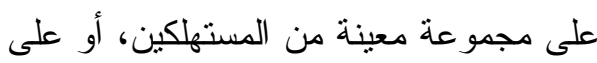

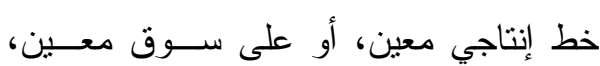
بحيث توضع كافة الإمكانات في خدمته.

إدارة التنافس اســتراتيجيًّا (Strategic)

:Management Of Competition

تُعتبر استر اتيجيات "مايكــل بــورنزر"

(Michael Porter)

للتفكير الاستر اتيجي في مجال إدارة عمليات التتافس الاستر اتيجي.

فقد ابتكر Porter مجموعــة مـن

المتطلبات في مجال بناء المهار ات، وتــوفير

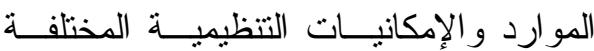
المطلوبة للاخول في تتافس إيجابي فعَّال مع

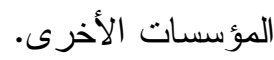

إن النجــاح فــي اســـتخدام أبيّ مــن

الاستر اتيجيات، التي سبق الحــديث عنهـــا،

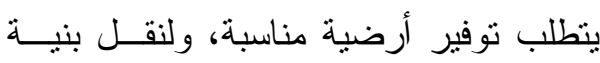

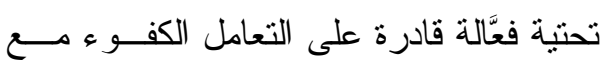
الحجم المتوقع من التفاعلات التتافسية، التـي يتطلبها العمل فيما بعد.

تو افقا مع معيــار ان الرشــاقة فـي

المنظمات هي استر اتيجية للنجاح في البيئات
البــــائل الاســـتر اتيجية علـــى مـسـتوى

الاستر اتيجية الوظيفية:

تهدف هذه الاستر اتيجيات إلى تحسين

الوضع التتافسي لوحدات العمل الاستراتيجية

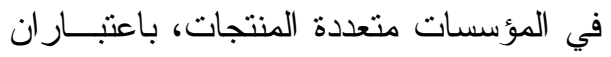

الرشاقة الاستر اتيجية هي القدرة على زيــادة

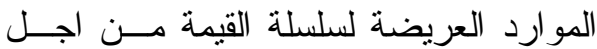

استخدامها وتوفير المنتجات المناســبة فـــي الوقت المناسب في ای مكان (·r)، و على هذا ولثان المستوى من الاســتر اتيجية فــي المؤســسة يتو افر ثلاثة أنو اع من البدائل الاستر اتيجية:

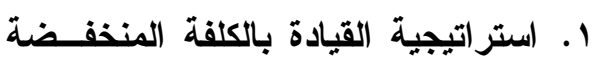
:(Overall Cost Leadership)

تتضمن هذه الاستر اتيجية تخفـبض

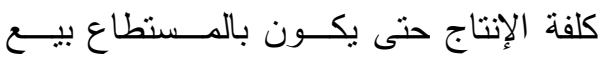

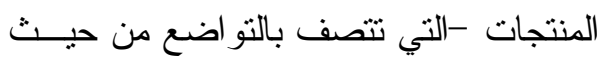

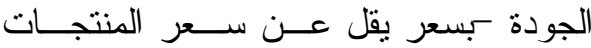
المنافسة في أسو اق المؤسسة. r ا ب استر اتيجية التفرد

\section{(Differentiation)}

تتطلب هذه الاستراتيجية إنتاج منتج

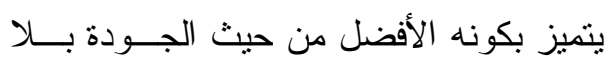

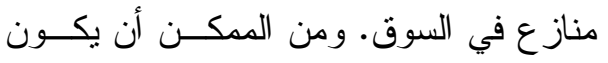
الأفضل بصفة ما.

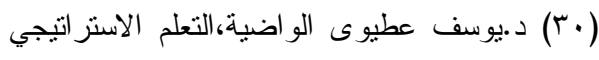

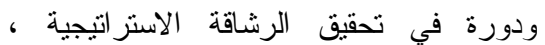

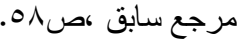




$$
\begin{aligned}
& \text { مثيل له في السوق، تُسمى مؤسسة رائـدة. } \\
& \text { عاليـــة التتافـــية و الديناميكيـــة وللمرونــــة }
\end{aligned}
$$

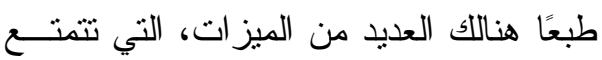

$$
\begin{aligned}
& \text { و هنا لابد من استخدام مجموعة مــن بها المؤسسة الرائدة. }
\end{aligned}
$$

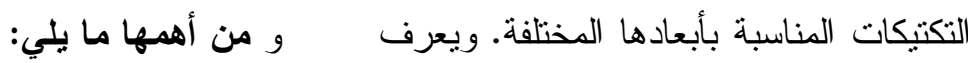

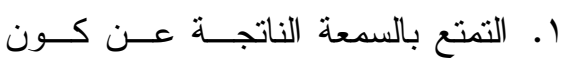

$$
\begin{aligned}
& \text { المؤسسة رائدة في حلبة التنافس. }
\end{aligned}
$$

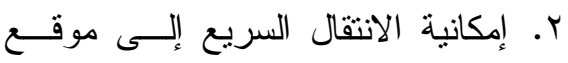

$$
\begin{aligned}
& \text { القيادة بالكلفة المنخفضة. }
\end{aligned}
$$

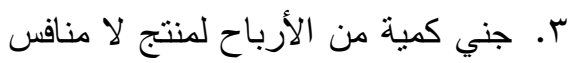

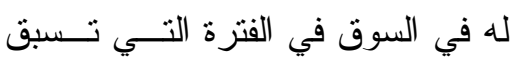

$$
\begin{aligned}
& \text { دخول المنافسين الجدد. }
\end{aligned}
$$

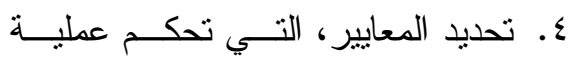

$$
\begin{aligned}
& \text { التتافس باستخدام هذا المنتج الجديد. } \\
& \text { من الأمثلة العملية على ذلك: نظــام }
\end{aligned}
$$

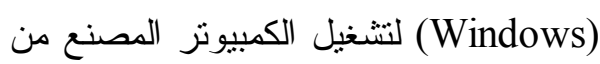

$$
\begin{aligned}
& \text { قبل شركة مايكروســـوفت، ونظــــام تـصنح } \\
& \text { الإنترنت من قبل شركة (Netscape). }
\end{aligned}
$$

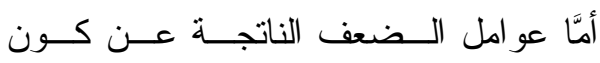

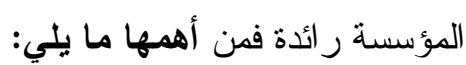

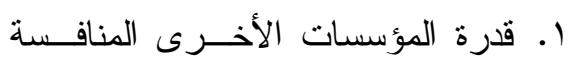

$$
\begin{aligned}
& \text { على تقليد المنتج بعد فترة منباينة }
\end{aligned}
$$

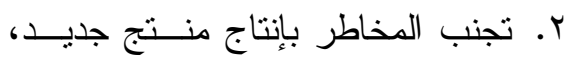

$$
\begin{aligned}
& \text { و إيجاد سوق له. } \\
& \text { التكتيك المكاني: } \\
& \text { يركز هذا التكتيك على الإجابة علـى }
\end{aligned}
$$

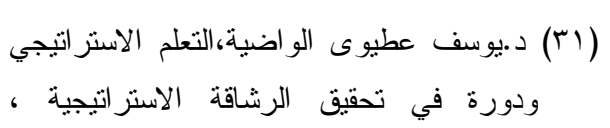

$$
\begin{aligned}
& \text { يحين موعد التنفيذ. } \\
& \text { التكتيك الزماني: موعي: } \\
& \text { يرسم التوجة الاستراتيجي الصركــة }
\end{aligned}
$$

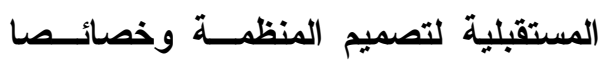

$$
\begin{aligned}
& \text { داخليا من جهة والية تفاعلها مع عوامـلـل وخلئل } \\
& \text { بيئتها الخاصة و العامة (rr). } \\
& \text { ويركز التكتيك الزماني على الإجابــة }
\end{aligned}
$$

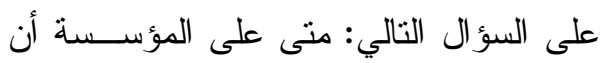

$$
\begin{aligned}
& \text { تبدأ عملية التنافس؟ هل ترغب المؤسسة أن }
\end{aligned}
$$

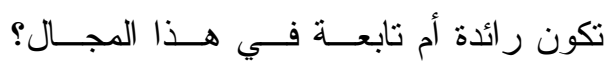

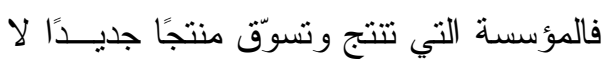

$$
\begin{aligned}
& \text { السؤال التالي: أين سيتم التتافس، أب ما هو الإبه } \\
& \text { السوق المناسب لذلك؟ }
\end{aligned}
$$

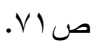

$$
\begin{aligned}
& \text { (Tr) د.نائر شاكر محمود الهيتى، د. سامى ذياب }
\end{aligned}
$$

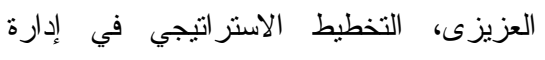

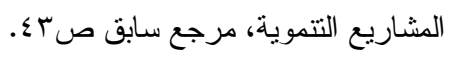


البساط" من تحـــت أقــــام المؤســسة

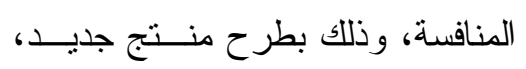
يؤدي إلى أن يصبح منتج المؤسـسـة ولنة المستهدفة الحالي غير ضروري.

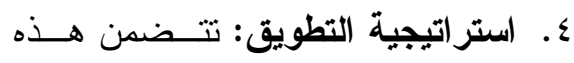
الاستر اتيجية أن تقــوم المؤسـسـة أو لئهن إحدى وحدات العمل الاستر اتيجية فيها

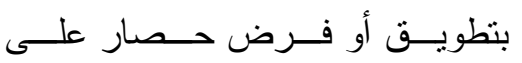
منتجات المؤسسة المنافسة، سواء كان

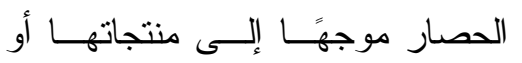
أسو اقها أو كليهما معًا. و هذا يتطلــبـ أن نتتج المؤسسة المهاجمة منتجـــات منتوعة تتراوح من المنتجات عاليــة

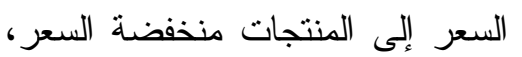
وتخدم أسو اقًا متعددة، أي تهيمن على الى أنى كافة أجز اء السوق. ه. (ستراتيجية حرب العصابات: تتطابق

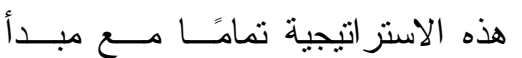
"اضرب واهرب"؛ حيث تقوم المؤسسة المهاجمة بتوجيه ضــربات ســريعة ومفاجأة دون تحقيق إصابات كبيــرة في المؤسسة المستهدفة، وذللك خــشية دفعها إلى الرد. أي أن هذه الضربات

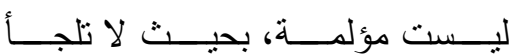

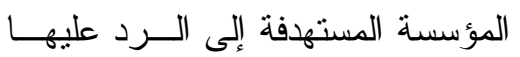
بسبب الكلفة العالية المحتملة لعمليــة

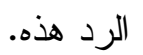

عادة تستخدم المؤسسة و احــدًا مــن

سبيلين لتتفيذ بديلها الاســتر اتيجي، فإمَّــا أن تستخدم أسلوب الهجوم، الذي ينفذ في ســوق لـون مؤسسة أخرى، أو أسلوب الدفاع كطريقـــة وقائية ضد دخول منافسين جدد محتملين إلى الى أسو اقها. التكتيك الهجومي: هناك العديد من الأساليب الهجوميـــة التــي اقترحها Porter، من أهمها ما يلي:

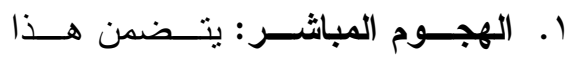

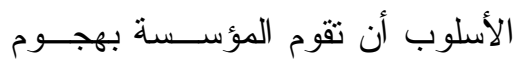
تتافسي مبانر على أسواق المؤسـسـة لـونة المنافسة. r. المناورة الجاتبية: بدلاً من الهجــوم

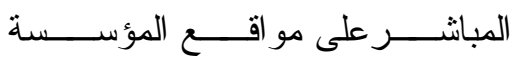

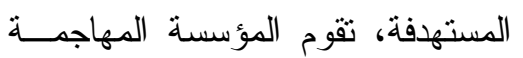

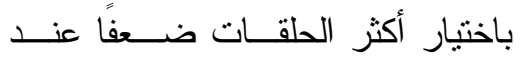

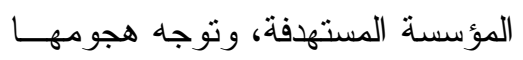
إلى تلك الحلقة. ولضمان النجاح على

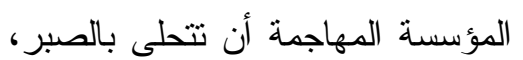

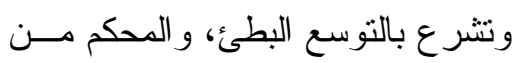

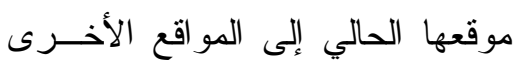
للمؤسسة المستهدفة. r. الاحعناء للعاصـفة: تتـضهن هـــهـ

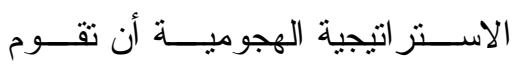
المؤسسة أو وحدة العمل الاستر اتيجية

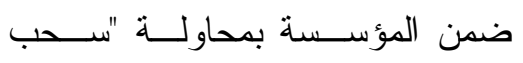




$$
\begin{aligned}
& \text { مُلزمة قانونيَّا مع المزودين. }
\end{aligned}
$$

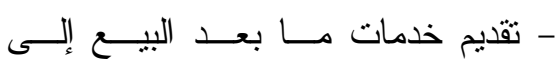

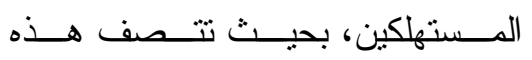

$$
\begin{aligned}
& \text { الخدمات بالجودة العالية. } \\
& \text { - رفع كُلفة اجتذاب المستهلكين الجدد من بالجودة العالة }
\end{aligned}
$$

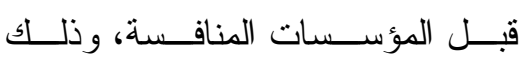

$$
\begin{aligned}
& \text { بالمحافظة على الحد الأدنى الممكن من }
\end{aligned}
$$

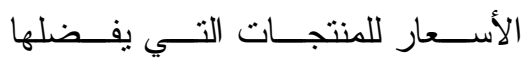

$$
\begin{aligned}
& \text { المستهلكون الجدد عادة. } \\
& \text { - البيع بأسعار منخفضة، وذلك بالاستفادة } \\
& \text { من اقتصاديات الإنتاج الواسع. }
\end{aligned}
$$

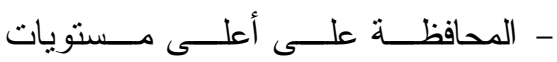

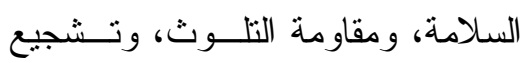

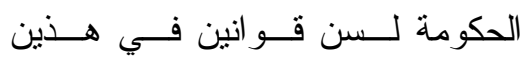

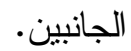

$$
\begin{aligned}
& \text { r. رفع احتمالية الــرد: يتـضمن هـــا } \\
& \text { التكتيك اتخاذ أي عمل يؤدي إلى جعل } \\
& \text { المؤسسات التي تفكر بالهجوم تتحسب }
\end{aligned}
$$

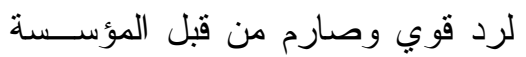

$$
\begin{aligned}
& \text { المستهدفة. } \\
& \text { r. تخفيض حوافز الهجوم: يركز هــذا } \\
& \text { التكتيك على تخفيض مستوى المنفعة، } \\
& \text { التي تتوقعهــــا المؤســــة المهاجمـــة، }
\end{aligned}
$$

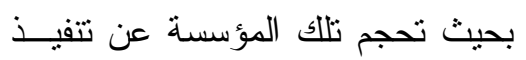

$$
\begin{aligned}
& \text { استر اتيجية الهجوم. } \\
& \text { تهدف التكتيكات الدفاعية -عادة -إلى } \\
& \text { تحقيق أحد الأمور التالية: }
\end{aligned}
$$

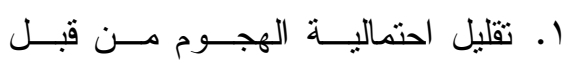

$$
\begin{aligned}
& \text { المؤسسات المنافسة. } \\
& \text { r. توجيه الهجمات المتوقعة إلى مسار ات اتهونيات } \\
& \text { تقلل من احتمالية إلحــاق أذى كبيــر } \\
& \text { بالمؤسسة المدافعة. } \\
& \text { r. تخفيف حدة الهجمات المتوقعة، بحيث } \\
& \text { تسنطيع المؤسسة مو اجهتهـــا بكفــاءة } \\
& \text { وفاعلية. } \\
& \text { أهم هذه التكتيكات: }
\end{aligned}
$$


فيها، واستبعاد النتائج غير المرغوب فيهــا، ويعد القرار الاستر اتيجي من الأهمية جوهر

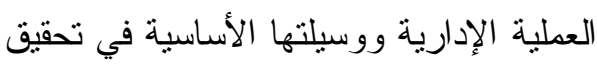

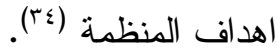

إن التفكير فى سمات البيئة: "التقلب، و التوجس، و التعقيد، و الغموض" (VUCA)

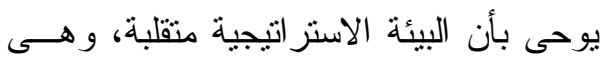

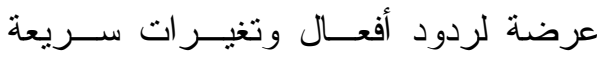

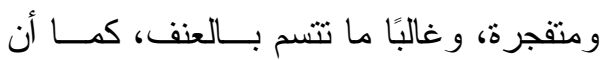
التوجس أو الثك من سمات هذه البيئة، وهو بطبيعته مثير للإنشكاليات، و غير مستقر .

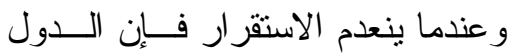
والأطر اف المعنية ستسعى فرديَّا وجماعيَّا

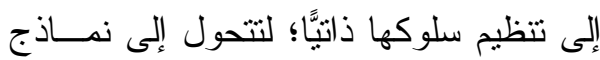

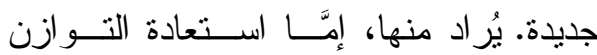

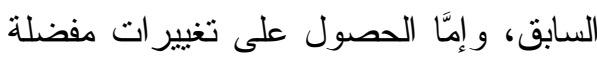
بالنسبة لمصالحها. ومهمة التكيــف بالنـسبة

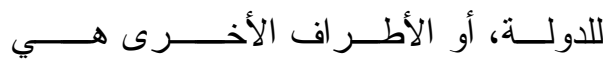

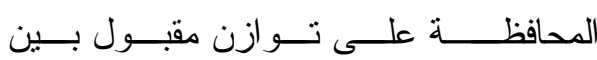
الاحتياجات الداخلية، و المطالب الخارجية. ولذلك يجب نوظيف جـهود وموارد كافية لتلبية طلبات البيئة الخارجية، ولكن فى

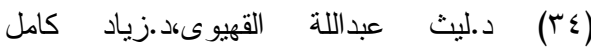

$$
\begin{aligned}
& \text { الالا،د.بلال محمدد الر ادى،جودة المعلومات }
\end{aligned}
$$

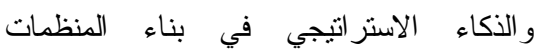

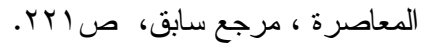

و المطورة في المنظمــة و التــي بــنت

تعلمها لتصبح طريقة جديدة وصحيحة للتفكير (rr)

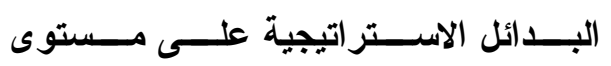
الاستر اتيجية التشغيلية:

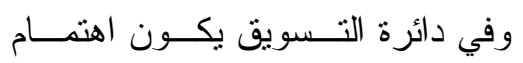

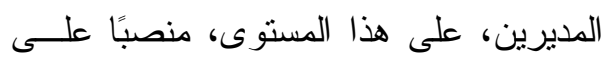

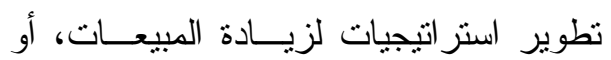
إنجاز جميع الأهداف التالية: ا. السيطرة على حصة أكبر من الأسواق الاقله القائمة. r. نطوير منتجات جديدة لتسويقها فـي الأسو اق القائمة حاليًا. r. إيجاد أسو اق جديدة للمنتجات القائمة.

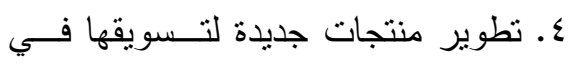
أسو اق جديدة بهدف زيادة المبيعات. • البيئة الاستر اتيجية: "كل شيء فى الاستر اتيجية بسيط جدًا،

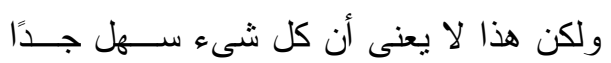

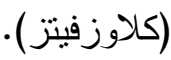

تسعى الاستر اتيجية لإحداث تأثنيرات

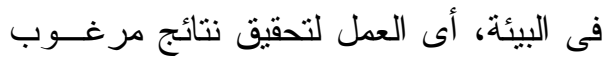

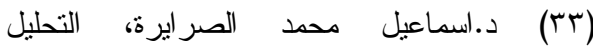
الاستر اتيجي في إعادة هندسة العمليات الإدارية،

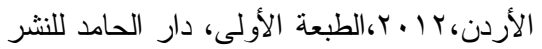

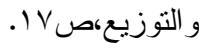


البشرية هي عبارة عن خطة تعطي المنظمة اتجاهًا طويل الأجل لتطوير الموارد البشرية،

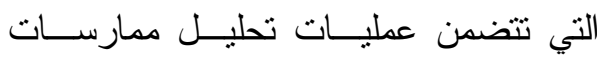

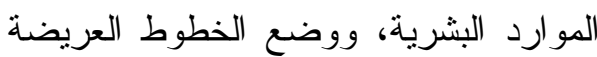

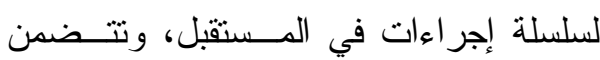
استر اتيجية الموارد البشرية عمليات تثتابعيــة تهدف إلى تكامل الممارسات البديلة للموارد

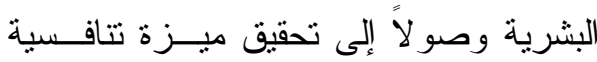

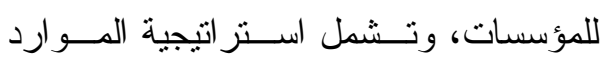
البشرية اتخاذ القرارات التي تحــدد رؤيسـة

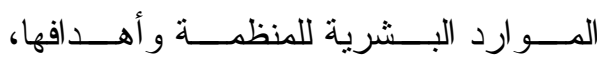
والاستخدام الفعَّل لموارد المنظمة، و السعي

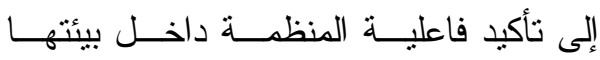
التظظيمية. وتدل التجارب الدوليــة فــي مجــال

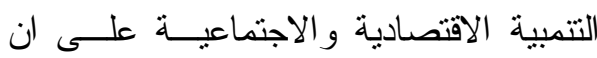

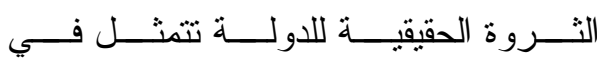

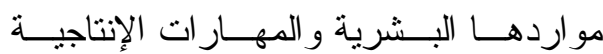
للقوى العاملة. (ז؟ن). ويمكننا القول إن استر اتيجية إدارة المـــوارد البشرية نتطوي على الأمور التالية: 1 - التحليل الاستر اتيجي:

ويتضمن تحليل البيئة الداخلية للمنظمة

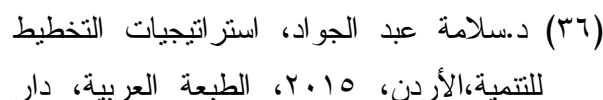

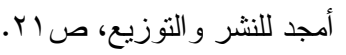

الوقت ذاته تجــب تلبية احتياجــــات البيئة

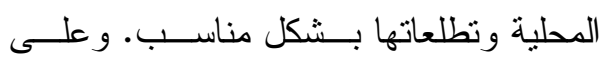
الأطر اف الفاعلة التكيف بصورة أو بــأخرى

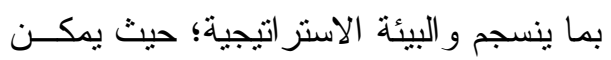

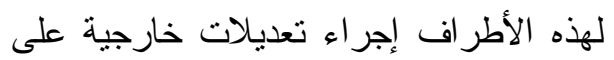
العلاقات فيما بينها، و على البيئة العامة، من إنداء أجل ضمان البقاء.

المطلب الثالث : استر اتيجية إدارة المــوارد البشرية يحتل موضوع تتمية الموارد البشرية

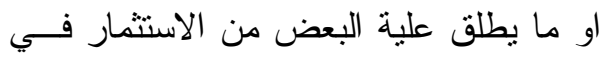

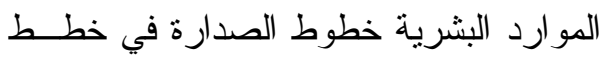
وبر امج الدول و الممنظمات التي تتشد التتمية و التقدم (ro). وقد عـرف (Dissler) اســتراتيجية إدارة الموارد البشرية أنها العلاقة بـين المـــوارد

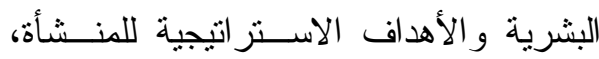
بغرض تحسين أدائها وتطوير نقافة المؤسسة من أجل زيادة مرونتها و إبداعها.

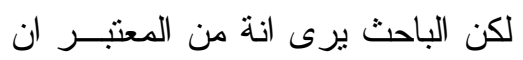

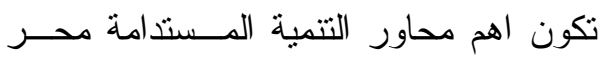

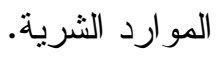
ويمكن القول إن استراتيجية المـــوارد د.ابر اهيم هديب، الاستر اتيجية التطويرية

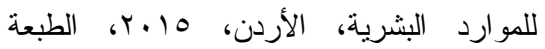

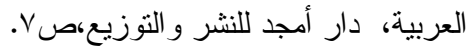


صياغة رؤية إدارة الموارد البشرية: يجب أن تستتد صـــاغة رؤيسـة إدارة الموارد البشرية إلى رؤية المؤسسة، التـي لئي تكون مشتقة منها. و الرؤية: عبارة فكرة تشحن الطاقات،

وتقفز للمستقبل باستدعاء المواهب و الموارد

التي تعمل على تحقيقها؛ حيث تقت بس إدارة

المو ارد البشرية رؤيتها من رؤية المنظمة. مكونات رؤية إدارة الموارد البشرية: الفلسفة الأساسية. حلم المستقبل.

وتوضح الفلـــفة الأساسـية لرؤيـــة

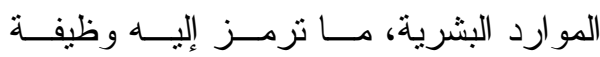

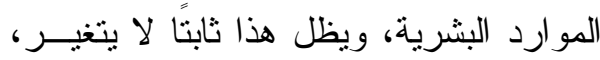
ويضيف إلى حلم الوظيفة و المنظمة.

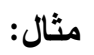

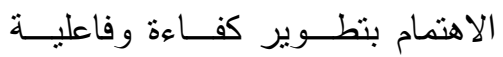

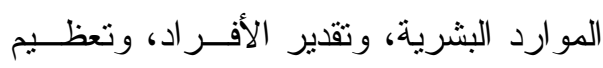

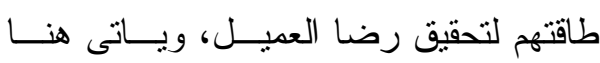
أهمية النوجية باعتبارة جوهر وظيفة المدير

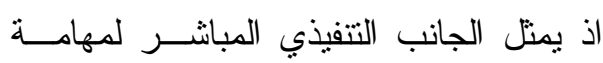

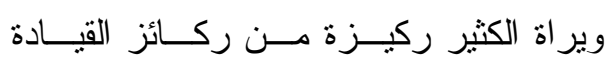
(ب)

(r^) د.ثابت أبو صيام، استرنتيجيات إدارة المؤسسات

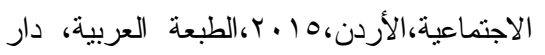

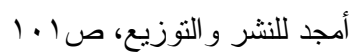

لمعرفة نقاط القوة و الضعف، وتحليل البيئــة الخارجية لمعرفة الفــرص و التهديــــات، أي وني أننا نستقيد من هذا التحليل فــي اســتر اتيجية إدارة المو ارد البشرية.

r البشرية، وتثمل ما يلي: - صباغة رؤية إدارة الموارد البشرية. - صباغة رسالة إدارة المو ارد البشرية. - صياغة أهداف إدارة الموارد البشرية.

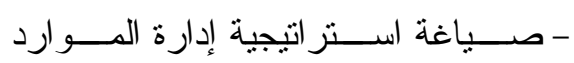

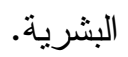

r - تنفيذ الاستر اتيجية من خــلال وضــع البرامج و الموازنات التقديرية وإجر اعت هنئ تنفيذ الوظائف المطلوبة.

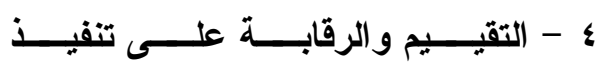
الاستر اتيجية:

ويعتبر تقييم الأداء وسيلة هامة فــي

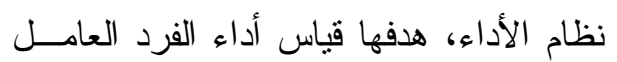

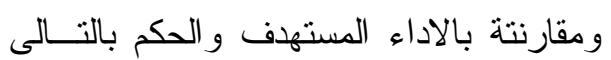

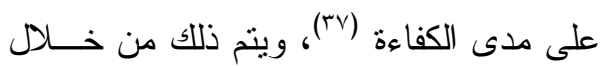

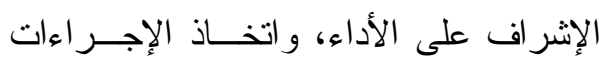

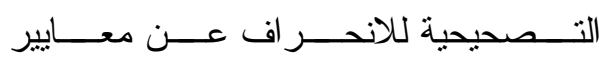

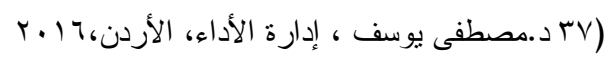
،الطبعة الأولى، مكتبة الحامد للنشر والتوزيع، الأردا،

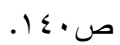




$$
\begin{aligned}
& \text { - خفض تكاليف اليد العاملة. } \\
& \text { - تتمية رضا العاملين. } \\
& \text { - تحسين الإنتاجية ونطوير ها. }
\end{aligned}
$$

صياغة استر اتيجية إدارة الموارد البشرية: وتعتبر عملية صــياغة اســنز اتيجية

لإِدارة الموارد البشرية في المؤسسة جـزءءًا

رئيسيًّا من التخطيط الاستر اتيجي للمؤسـسـة،

يتعلق بتوفير احتياجات المؤسسة من الموارد

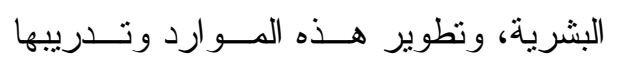

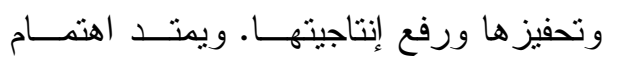

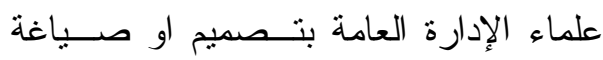

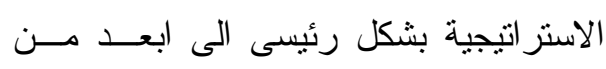

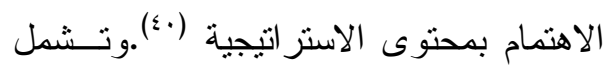
المجالات التي يمكن فيها وضع إســنز انيجية إدارة الموارد البشرية ما يلي: - الوصف الوظيفي المعتمد في المؤسسة.

$$
\text { - إدارة الموارد البشرية في المؤسسة. }
$$
- التتظيم الإداري لوظيفة إدارة المــوارد

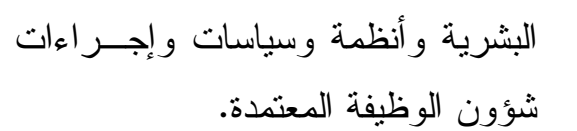

(•) مايز أندرو، جورج أ.بوين جنيفر لو،ريتشارد

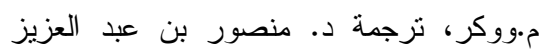
المعشوق، الإدارة الاستراتيجية و وأداء الخدمة العامة، معهز الإدارة العامة، مكتبة الملك فهر الإنه الوطنية، صع - 1.
يجب أن تستتد صياغة رســالة إدارة الموارد البشرية إلى رسالة المؤسسة، وتنكون

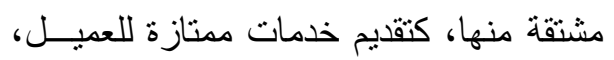

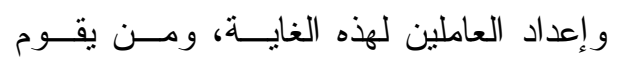
بالتوجية هم زو الخبرات و اكثر الأثــخاص ولهن

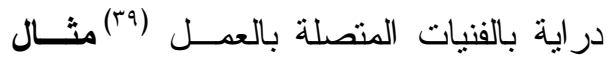
:الاهتمام بكافــة وظــائف و أنــشطة إدارة

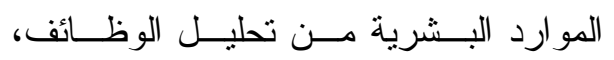

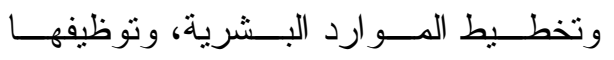
وتدريبها وتقييم أدائها، وتعويضها وصيانتها من أجل المحافظة على موارد بشرية كفو وة ونها وفاعلة نُسهم في تحقيق الميزه التتافسية. أهداف إدارة الموارد البشرية: توفير احتياجات المؤسسة من الموارد

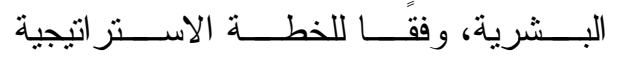
الموضوعة، وبالمو اصفات المطلوبة، وفــي ولئ الوقت المحدد. الحـرص علــى توظيــــ المـــوارد

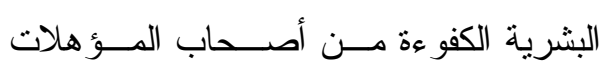
و الخبر ات العلمية و العملية. - صبانة الموارد البشرية. - تدريب العاملين في المؤسسة.

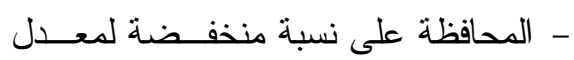
دوران العاملين. (49) د.ثابت أبو صيام، استرتيجيات إدارة المؤسسات الاجتماعية ، ص آس. 


\begin{tabular}{|c|c|}
\hline تكامل استراتيجية إدارة الموارد البشرية مع & 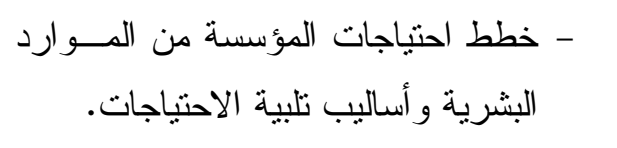 \\
\hline ان السلوك الاســتر اتيجي هـــو دالـــة & 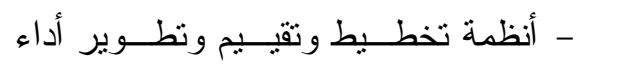 \\
\hline لخصائص الفرد الثخصية وخصائص البيئة & العاملين في المؤسسة. \\
\hline المحيطة بة (1ミ). & 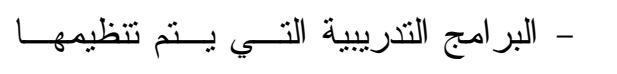 \\
\hline ينطلب الــدور الاســتر اتيجي لإدارة & للعاملين و البعثات التدرييية. \\
\hline الموارد البشرية التكامل و التتسيق و التفاعـلـل & - نظام إدارة الرواتب و المز ايا و الحــــو افز \\
\hline المستمر مع كافة الاستر اتيجيات. & و والمكافــــآت و الترقيـــــات وزيــــــادات \\
\hline مكونات استر اتيجية إدارة الموارد البشرية: & الموظفين المعتمدة. \\
\hline ع - - 1 -اســـتر اتيجية تخطـــبط المـــوارد & مثال: استر اتيجية إدارة المــوارد البـشرية \\
\hline البشرية. & لمؤسسة ما: \\
\hline ع - r - استر اتيجية التوظيف. & - إنهاء خدمات عدد محدد من العــاملين \\
\hline ع - r -استر اتيجية تدريب العاملين. & في وظائف الخدمات الإدارية. \\
\hline ع - ع -استر انيجية تقييم أداء العاملين. & - تجميد عمليات التوظيــف فــي الــسنة \\
\hline ع - ـ - -استر اتيجية الرواتـب و المزايــا & 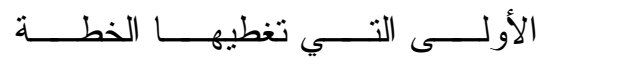 \\
\hline 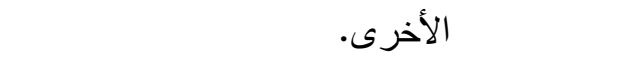 & الاستر اتيجية. \\
\hline و التكامل يكون من الكل إلى الجــزء، & - وضع معايير و اضحة لضمان اختــــار \\
\hline ومن الجزء إلى الكل، وقد تؤدي الظـــروف & المرشحين الأكفاء للوظائف الثـاغرة. \\
\hline البيئية إلــى تغييــر اســـتر اتيجية المنظمـــة & - - إعادة النظر في معايير تقييم الأداء. \\
\hline 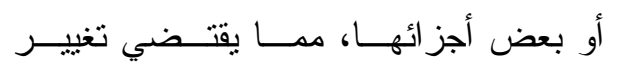 & - تتظيم بر امج تدرييية للعاملين في مجال \\
\hline استر اتيجية إدارة الموارد البشرية أو بعــض & الحاسوب و اللغة الإنجليزية. \\
\hline 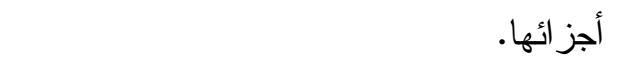 & - استخدام أسلوب تدريب العاملين أثتــــاء \\
\hline & 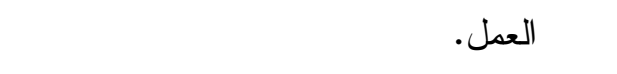 \\
\hline & - إعادة النظر في سلم الدرجات للرواتب \\
\hline (إ) د.معن وعد اللة المعاضيدى،د. وزيرة يحيى & 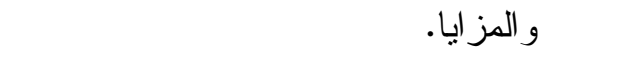 \\
\hline محمد سليمان، تاثير الذكاء التنافسى في تحديد & - وضع نظام جديد للحو افز . \\
\hline الخيار الاستر اتيجي على مستوى وحدة الاعمال، & \\
\hline 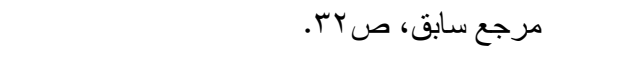 & \\
\hline
\end{tabular}




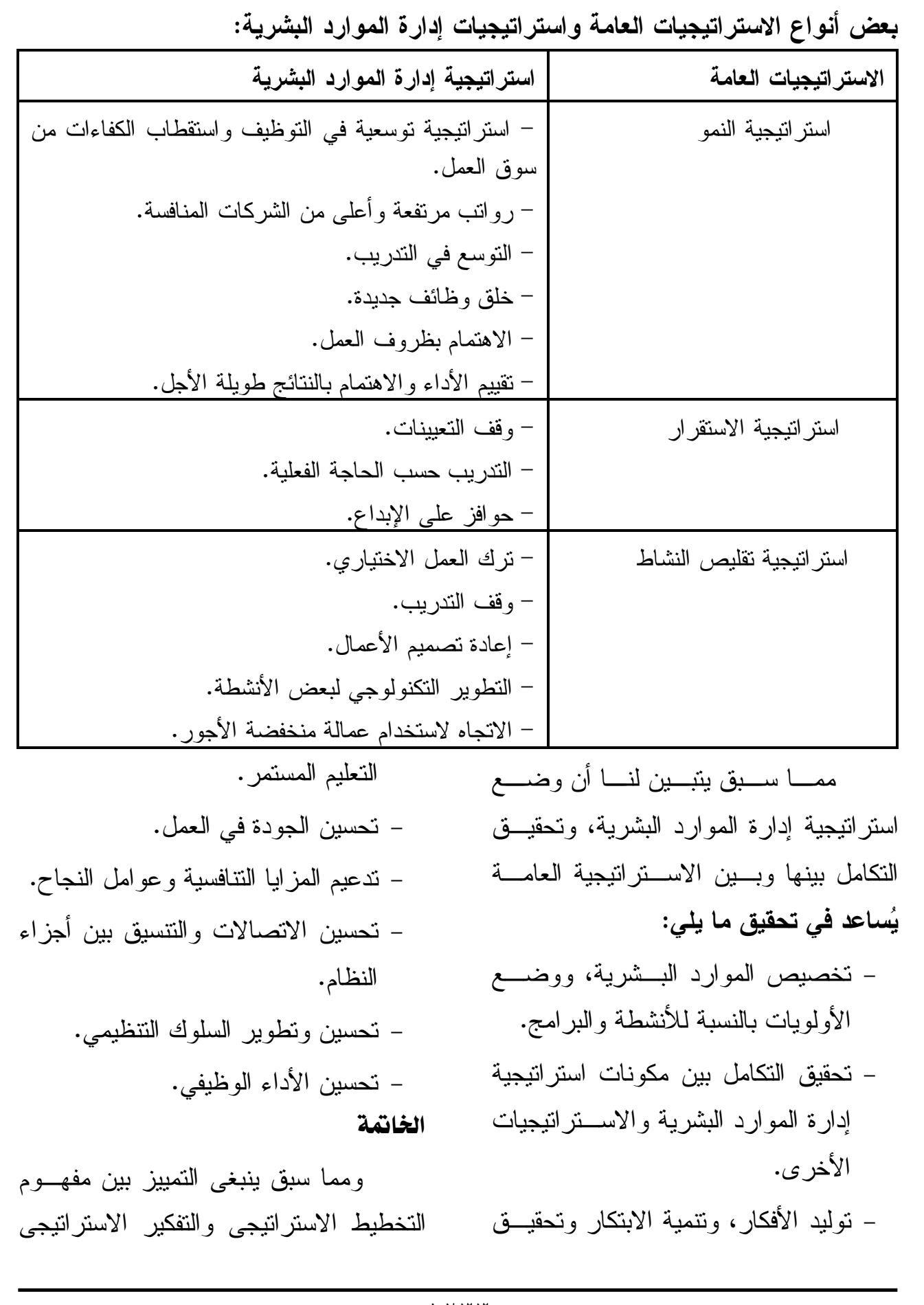




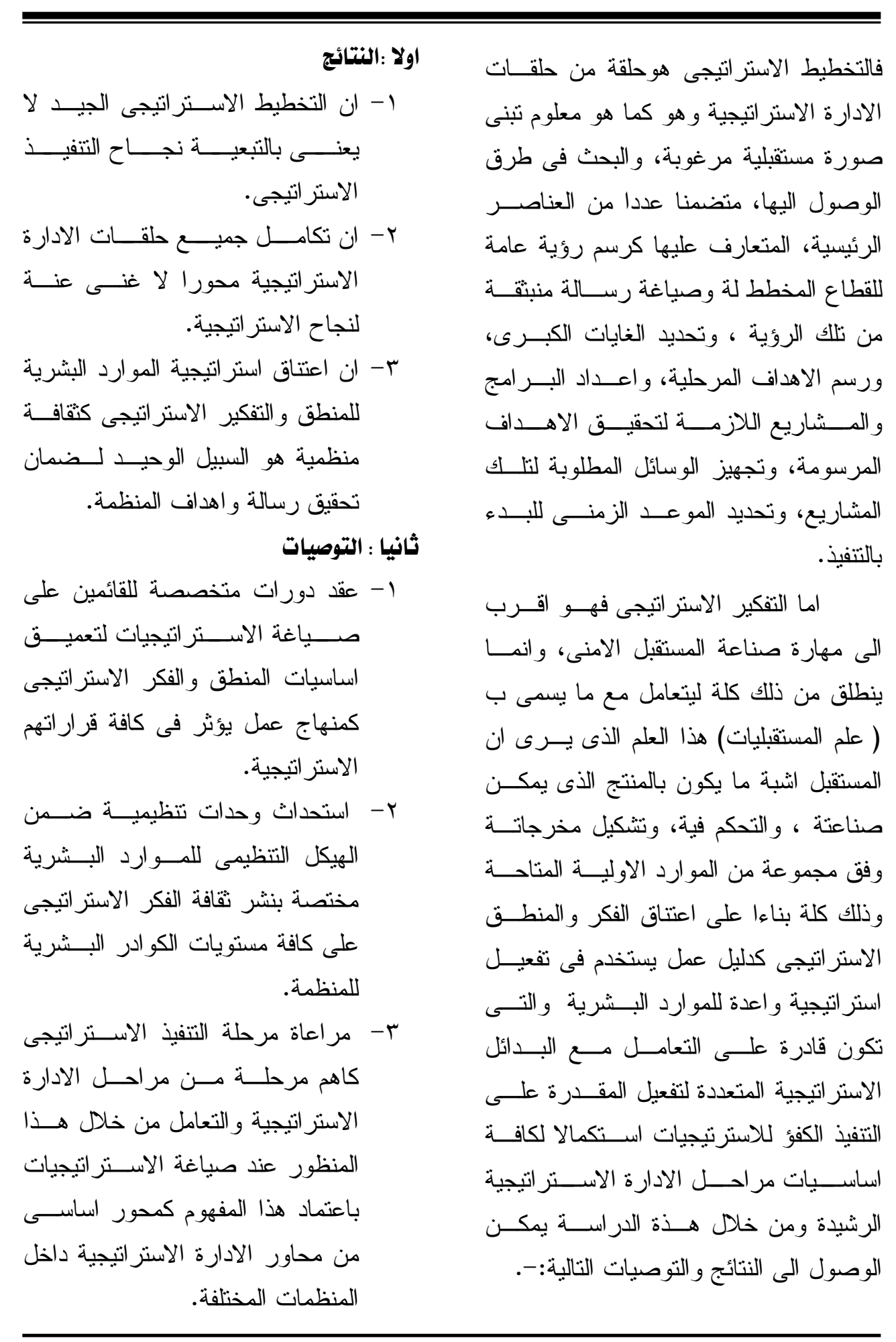




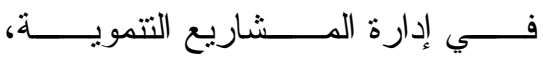

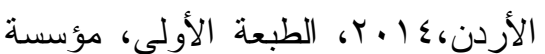

اولا : المراجع باللغة العربية الور اق للنشر و التوزيع.

^. جوو ايتهيــد، ترجمــة د. حسـسن عبــد

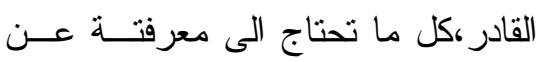

الاستر اتيجية، القاهرة، با ـ ب، الطبعــة

الأولى، دار الفجر للنشر والتوزيع.

9. ذكريا الدورى،د.احمد علــى صــالح،

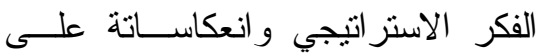

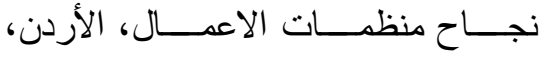

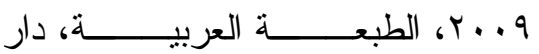
اليازورى العلمية للنشر و التوزيع.

• ا.ر ايز أندرو، جــورج أ.بـوين جنيفـر

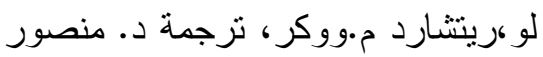

بن عبــــ العزيــز المعـشـوق، الإدارة

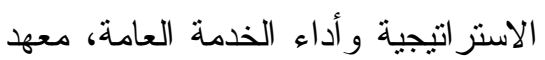
الإدارة العامة، مكتبة الملك فهد الوطنية.

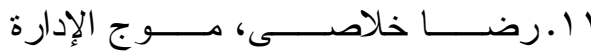

الاستر اتيجية، الجز ائر كبدون سنة نــشر ، دار هومة للنشر و التوزيع.

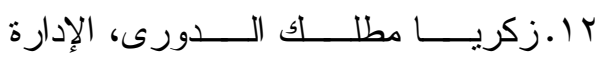

الاستر اتيجية مفاهيم و عمليات وحـالات

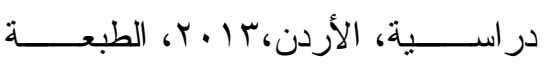

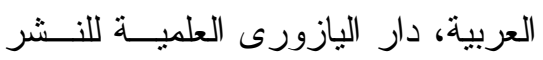

و التوزيع - (التزبه، دان

1 . ابر اهيم هديب، الاستر اتيجية النطويرية

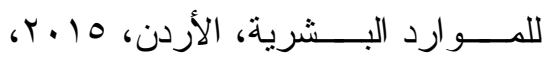

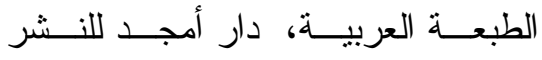

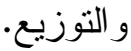

r. أثمار عبد الر اذق، استر اتيجية التكامــل

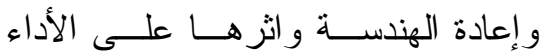

الاســتز اتيجي باســتخدام بطاقـــة الأداء

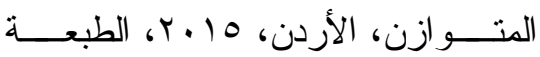

الأولى، دار الحمد للنشر و التوزيع.

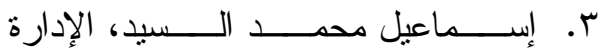

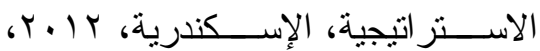

الطبعة الأولى، المكتب العربى الحديث.

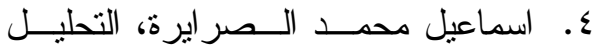

الاستر اتيجي في إعادة هندسة العمليـات

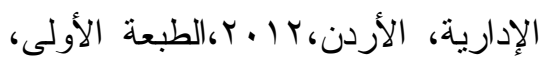

دار الحامد للنشر و التوزيع.

0. تامر البكرى،د.احمد الصقال، التحليـلـ

الاستر اتيجي و الميزة التتافسية، الأردن،

T1 أr، دار امجد للنشر.

7. ثابت أبــو صـــام، اســترتيجيات إدارة

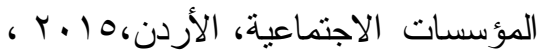

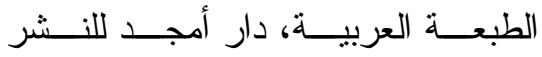

و التوزيع.

V. ثائر شاكر محمود الهيتـى، د. ســامى

ذياب العزيزى، التخطيط الاســتراتيجي 
$\ddot{a}$

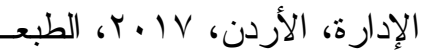

الأولى، دار الحامد للنشر و التوزيع

9 1 . محمـــــد فخـــــرى ر اضـــــــــالإدارة

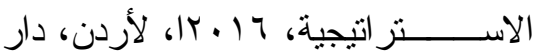

أمجد للنشر و التوزيع

• . . مشيرة السعداوى، اســتر اتيجية العمــل

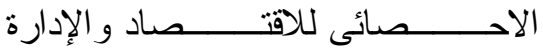

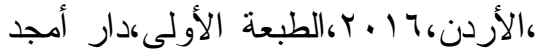

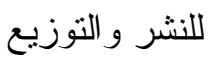

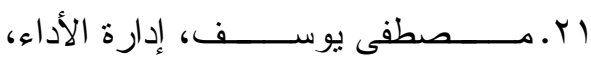

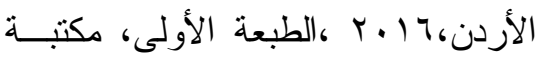
الحامد للنشر و التوزيع.

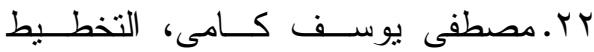
و التتمية من منظور (اقتصادى، بيئـى، اعلامى) الاردن، IV I I.الطبعة الأولى، دار الحامد للنشر و التوزيع.

rr. معن وعد اللة المعاضيدى، د. وزيـرة يحيى محمــد ســليمان، تــاثير الــذكاء التتافسى في تحديد الخيار الاســـر اتيجي على مستوى وحدة الاعمــال، الأردن، 10 للنشر و التوزيع.

ع . هيثم عبداللة ذيب، أصـــول التخطــيط

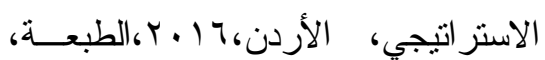

$$
\text { دار اليازورى للنشر و التوزيع }
$$

با . سعد على العنــزى،د.جـــو اد محــسن

راضـى، التحالفــات الاســـر اتيجية فـــي

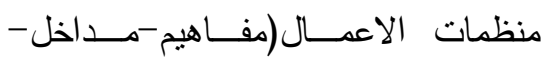

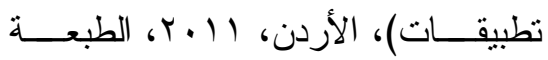
الاوللى، دار اليازورى العلميــة للنــشر و التوزيع.

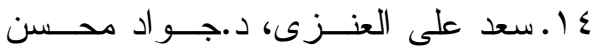
راضـى، التحالفــات الاســـر اتيجية فـــي

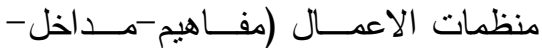
تطبيقات )، مرجع سابق. 1 ــــلامة عبــــ الجــو اد، اســتر اتيجيات التخطيط للتتمبة،الأردن، 10 ـ ب الطبعة الطبة العربية، دار أمجد للنشر و التوزيع. 7 ا ـ طلال محمد الججاوى، ساكنة السلطانى،

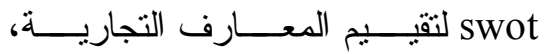
الأردن، ع ا ـ r، الطبعــــة العربيـــة، دار اليازورى العلمية للنشر و التوزيع. IV ليث عبداللة القهيــوى، د.زيــاد كامـلـل

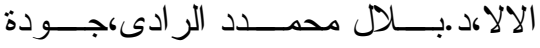
المعلومات و الذكاء الاستر اتيجي في بناء المنظمات المعاصـــرة، ا ـ بـ، الطبعــة الالىى، دار الحامد للنشر و التوزيع. 1 ا.متعب الزبن، البناء الاستر اتيجي للدولة

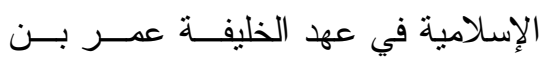

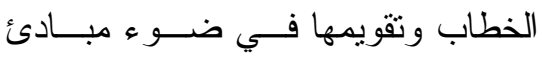


Management. 2nd edition, McGraw-Hill Irwin Ed., New York

3. French S, 2009.Critiquing the language of Strategic management. Journal of Management Development, 28 (1).

4. French S. 2009. Re-framing strategic thinking: the research aims and outcomes. Journal of Management Development, 28(3).

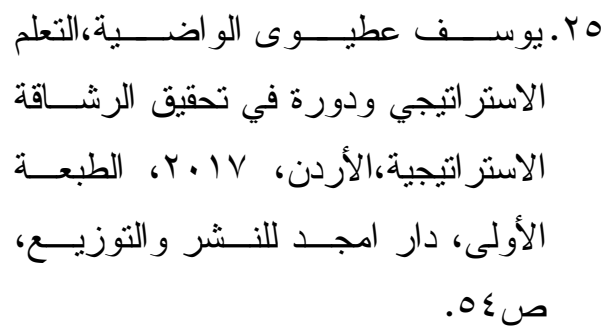

1. Casey A and Goldman E F. 2010. Enhancing the Ability to Think Strategically: A Learning Model. Management Learning, 41(2).

2. Dess G, Lumpkin G and Taylor M. 2005. Strategic 